\title{
Milateuki Collection
} japantese Fine Qrts 


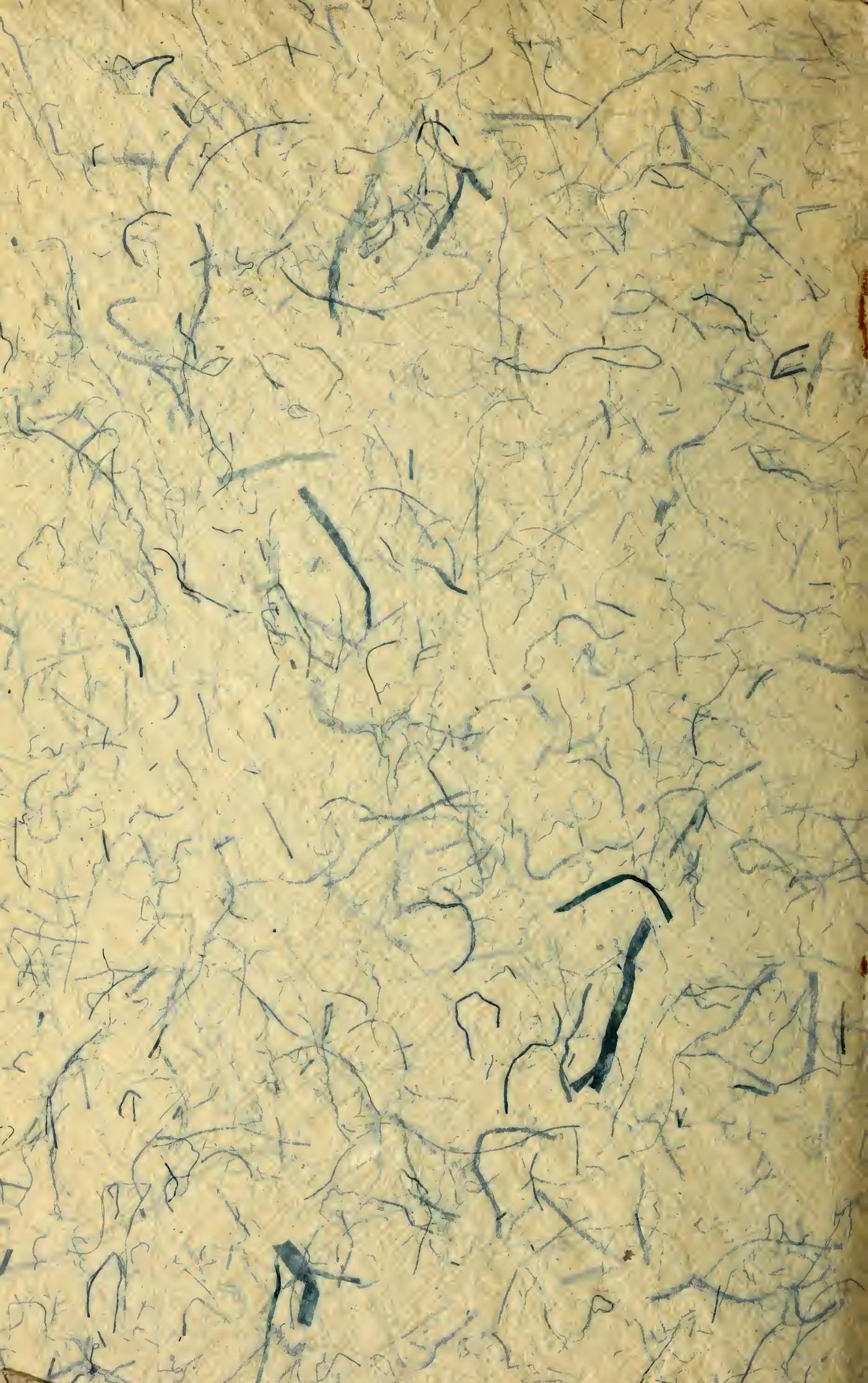


3088. 


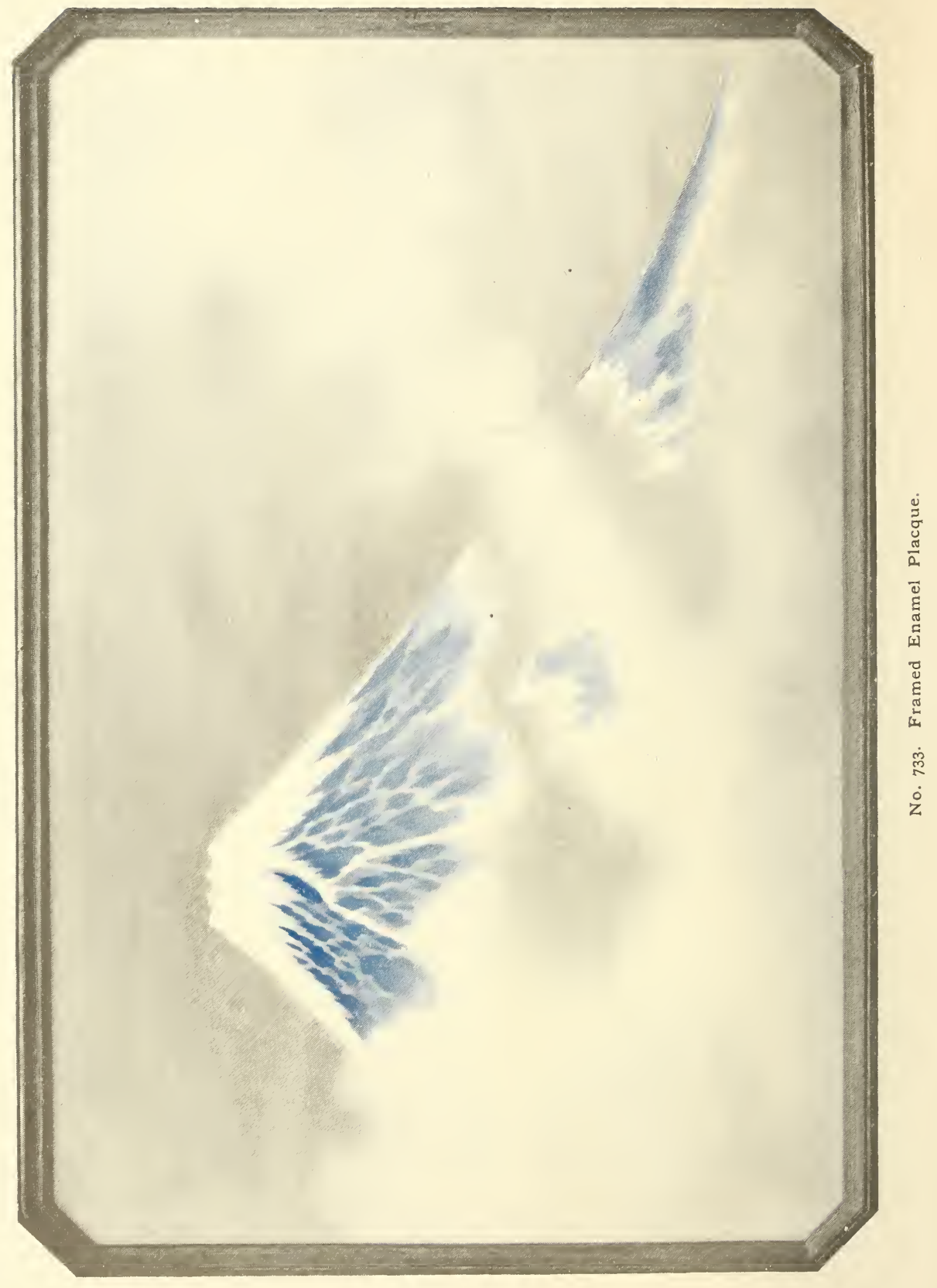


. 


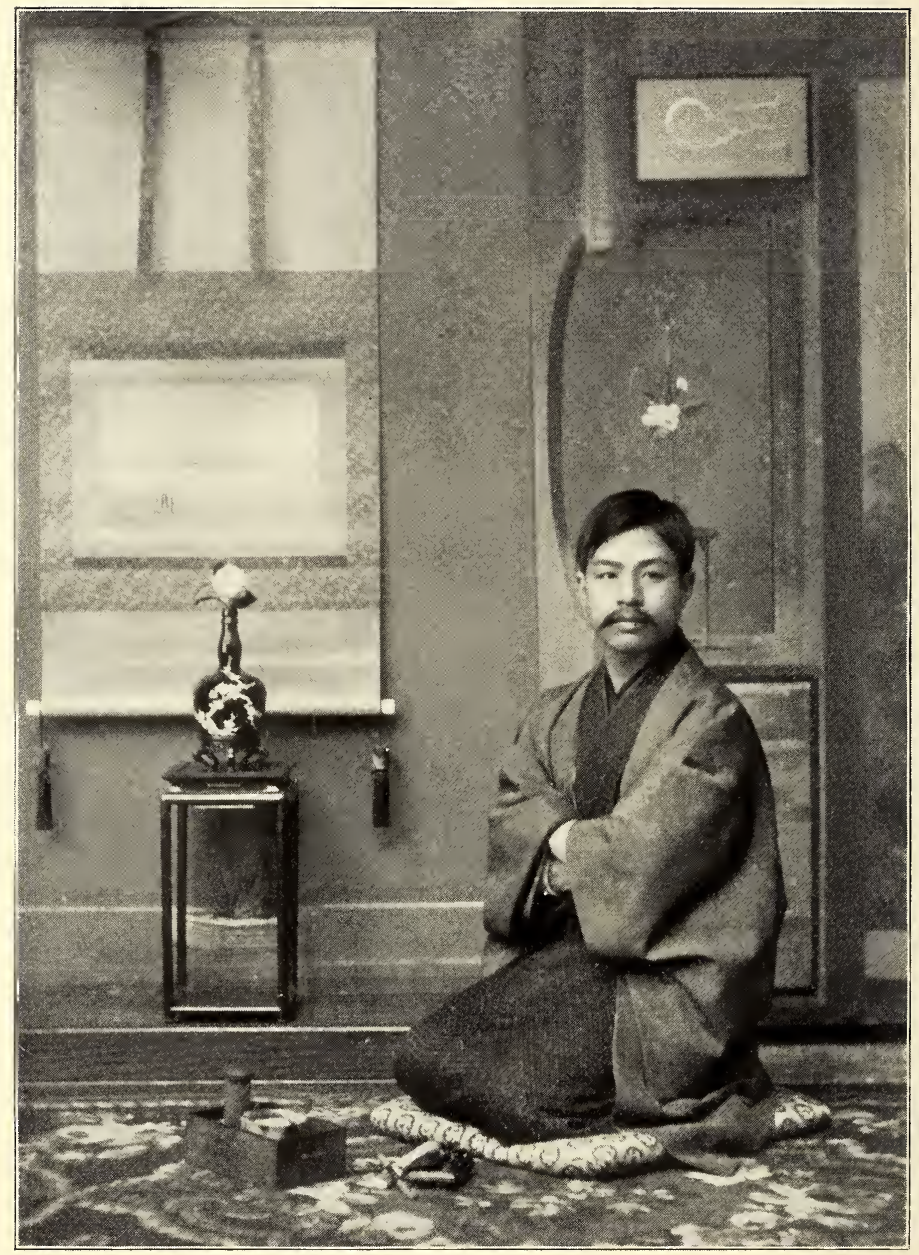

BUNKIO MATSUKI (THE COLLECTOR), IN JAPAN. 


\title{
DESCRIPTIVE CATALOGUE
}

OF AN

IMPORTANT COLLECTION

OF

\section{JAPANESE AND CHINESE}

POTTERY, PORCELAIN, BRONZES, BROCADES, PRINTS, EMBROIDERIES, KAKEMONO, SCREENS, IVORIES AND

\section{GOLD LACQUERS.}

\author{
SELECTED BY \\ MR. BUNKIO MATSUKI
}

OF

KOBE, JAPAN AND BOSTON.

TO BE SOLD AT AUCTION

Thursday, April Twenty-First, 1898

AT 3.00 O'CLOCK, P. M., AND

EVERY FOLLOWING AFTERNOON UNTIL SATURDAY, APRIL 30, INCLUSIVE.

LEONARD \& COMPANY'S GALLERIES,

46 \& 48 Bromfield St., Boston,

WHERE THE COLLECTION IS NOW ON EXHIBITION 
Copyright, i898, by James F. Almy.

BOSTON

PRESS OF OLVIN H. LUFKIN, 145 HIGH STREET. 1898. 


\section{PREFATORY NOTE.}

The collection here exhibited has been made by me personally and by my special agents for the last ten years. Many of them are of great value to me personally because of their merit from a purely Japanese standpoint of art, and have never before been shown to the public at large. 


\section{RULES AND CONDITIONS.}

Bills payable in cash before delivery.

Bills must be sent for delivery of goods.

Goods to be removed at the expense and risk of purchaser, immediately after the sale.

Goods not removed on the day of sale remain at the risk of the purchaser.

No claims allowed after the removal of goods.

Articles are exposed for examination, and are sold without guaranty.

Articles are resold at the expense and risk of the purchaser.

Deposits must be given when requested.

Our record of sales in all cases final.

Orders to buy executed without charge.

LEONARD \& CO., Boston. 



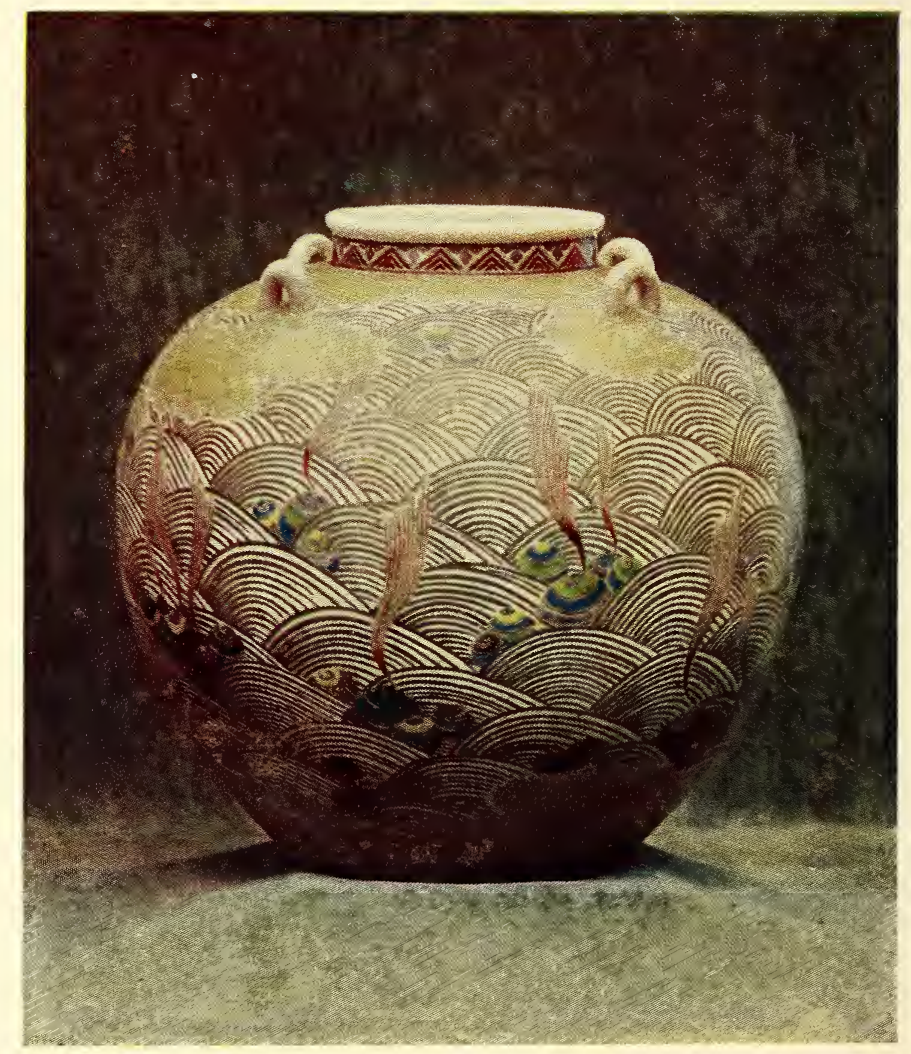

No. 8,6

Faience Jar by NonOmura NinSEI 1630 a. D. 


\section{ORDERS EXECUTED WITHOUT CHARGE.}

\section{CATALOGUE.}

First Day's Sale-Thursday, April 21, at 3.

I Old Silk Embroidery. Design, Sacred Howo Bird (said not to eat live insects or to tread on green grass) and Sacred Kiri Flowers in pale blue and white silk on soft brown ground. The entire space is covered with needlework; border of Shichin Silk. Size, 5 feet $\mathrm{x} 4$ I-2 feet.

2 Old Awata Bottle. Japanese Kikyo flowers painted in various colored enamels on beautiful crackled ground. Height, 7 I-2 inches.

3 Old Idzumo Vase, in form of roll of Buddhist scripture. Height, Io inches.

4 Old Banko Vase. Decoration in dark brown on soft gray ground. One of the earliest of the Banko, date about I 760. Mark, Banko. Height, I I inches.

5 Green Bronze Bowl. Thick and heavy and of superb green color. Perfectly smooth finish. Made about I 800. Height, 3 I-2 inches. Diameter, 4 I-2 inches.

6 Yatsushiro Vase. Banana leaf incised in white on warm gray ground. Beautiful texture. Date about 1830 . Height, Io inches.

7 Kioto Dish with handle. Made by Yeiraku Zengoro after the style of Hagi ware. Delightful gray glaze. Mark, Kwahin Shiriu.

8 Bronze Incense Burner in form of peach and wasp. Wonderful glowing color. Good specimen of old bronze. Date about I 730. Height, 6 inches. 
9 Old Hagi Jar. Stripes of yellow and brown enamel on opal gray glaze. Height, 7 inches.

Io Golden Bronze. By Jomin, about I 780 . Height, 9 I-2 inches. Design, bat in pursuit of butterfly in relief in Shakudo metal. Both bat and butterfly are full of motion and the motive of bat is plainly apparent. The golden bronze is of rare quality. This is one of the most charming specimens of work executed by Jomin. Has fine teakwood stand.

I I Porcelain Vase by Makuzu Kozan. Decoration, plum tree in blossom in white enamel on coral red ground. With teakwood stand. Height, I 2 inches.

I 2 Tea Bowl, Faience, by Makuzu Kozan in Kioto. Floral decoration on beautiful gray ground. Date about i 860. Mark, Makudzu.

I 3 Tea Bowl, Faience-Kioto Ware. Shiny opal glaze on reddish brown clay.

I 4 Takemoto Vase. Soft blue and brown glaze covers upper portion of vase. Mark, Riosai Inouye. Height, I 2 inches.

I 5 Bronze Vase. By Nagoshi Yechigo no Kami, bronze maker to Kioto Palace about I720-I750. In form of morning glory with handles of wonderful curvature. Signed, Yechigo no Kami. Height, 12 inches.

I6 Bronze Dish; shape of Kanaye, ears in form of imp. Height, 7 I-2 inches. Diameter, 8 I-2 inches.

I 7 Old Ofuke Dish; round vessel with heavy glaze and sweet painting of stork on outside. I700 A. D. Diameter, 14 inches.

I 8 Kioto Vase. Faience. Beautiful blue glaze covers whole vase. Cylindrical in form. With teakwood stand. Height, I 5 I-2 inches.

I9 Old Imari Covered Bowl. Porcelain, Octagonal, deceration, "Crows and Winter Scenery" painted under glaze. Date, i730. A. D. 


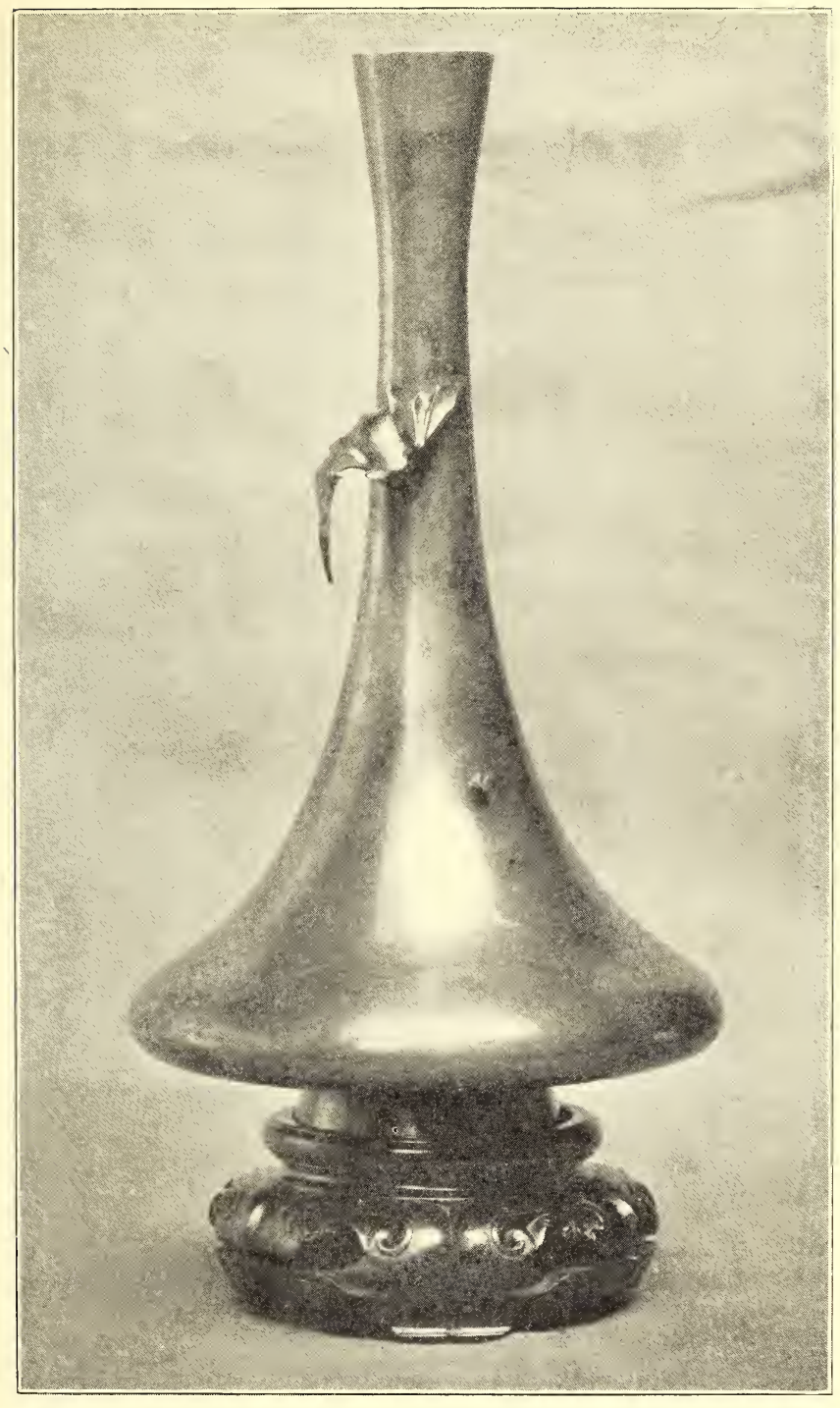

No. 10. 

20 Old Oribe Bowl. Mark, Tenke.

2 I Mino Dish, in form of shell with lacquered cover. Mark, Sanko. Date about I 800.

22 Old Bronze Vase. Flaring into broad diamond shape top. Conventional design on body and neck of the vase. Height, I 4 inches. Date, I 70o. With teakwood stand.

23 Bronze Hibachi. Known as scarlet bronze on account of color. Beautiful smooth glaze. Made by Nagoshi, I 7 So. Height, 8 inches. Diameter, Io inches.

24 Covered Dish. Decoration, Japanese fruits in various colored enamels. Made at Okogi in Province of Ise. Mark, Okogi.

\section{NO'TE.}

Meizan Satsumas. The work is done under magnifying glass. Every detail is executed in the most perfect manner. Visitors are requested to inspect them using magnifying glass.

25 Satsuma Bowl. Outside is decorated with sixty varieties of chrysanthemum and fine brocade patterns. Decoration inside the bowl gives glimpses of Japanese life in summer time, with a border of tiny landscapes and native flowers of the four seasons.

26 Satsuma Tea Cady. Decoration, Sacred Howo Bird.

27 Lacquered Palace Lantern. Globe is decorated with Japanese native iris and wistaria. Height, 38 I-2 inches.

28 Awata Water Jar. Chinese landscape painted under the glaze. Height, 7 inches.

29 Yatsushiro Bottle. Pine tree and stork painted under the glaze. Date, I830. Teakwood stand. Height, 9 inches.

30 Kioto Bowl by Yeiraku. Decoration, moon and autumnal flowers. Mark, Yeiraku.

3 I Banko Bottle in form of gourd. Decoration in red and green enamel. Date, I 730. 
32 Tea Bowl. Made by Seventh Raku. Color rich yellow and green.

33 Raku Tea Bowl. Decoration, leaves of the arrowhead in yellow enamel on gray ground.

34 Huge Bizen Bowl in form of Lotus leaf; three crabs crawling on the outside. Very rare specimen. Height, Io inches. Diameter, I6 inches. (See illustration.)

35 Bizen Flower Pot. Lion and blossoms of peony carved in relief. Supported on three feet formed by heads of imps. Height, I 4 inches. Diameter, I 3 3-4 inches. Rare specimen. (See illustration.)

36 Bizen Punch Bowl. Two crabs in relief crawling on inside of bowl. Height, 9 inches. Diameter, 22 inches. Rare Specimen. (See illustration.)

37 Bronze Vase. Conventional border in relief near base of vase. Beautiful blending of green and red. Date, I 750. Height, I I inches.

38 Old Idzumo Tea Bowl. Decoration, lobster and leaves of the bamboo painted in red and green enamel.

\section{NOTE.}

Kakiyemon lived between 1600 and 1660 in Nangawara near Arita in Province of Hizen. He was the first to decorate porcelain with enamel. His work became so famous that it was much sought after by Chinese traders at Port of Nagasaki, the Prince of Kaga and many other Daimyos. "Later he was honored by Prince Nabeshima by being appointed a special porcelain maker to his Highness, and his reputation quickly spread all over Japan."

The style of his enamel painting is exceedingly delicate. Subdued enamel colorings on porcelain is an inimitable art attained by Kakiyemon alone. His work is extremely rare. The following specimens are among the important ones in the collection.

39 Incense Burner in form of persimmon. Decoration, Japanese poet in his garden, in blue and green enamel on porcelain of finest texture. (See illustration.) Date, I630. By Kakiyemon. Height, 3 I-2 inches. 


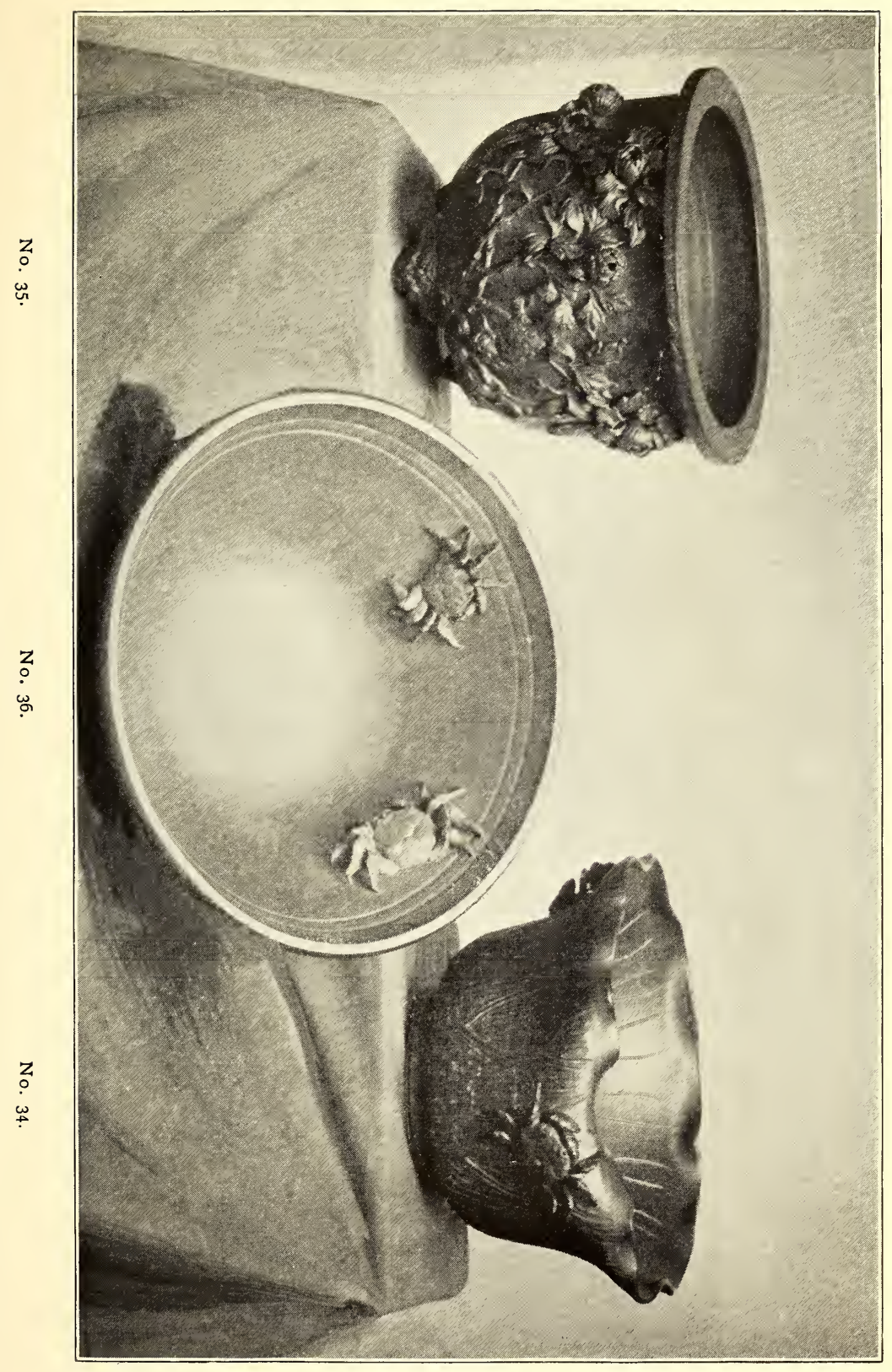





$$
\text { - }
$$




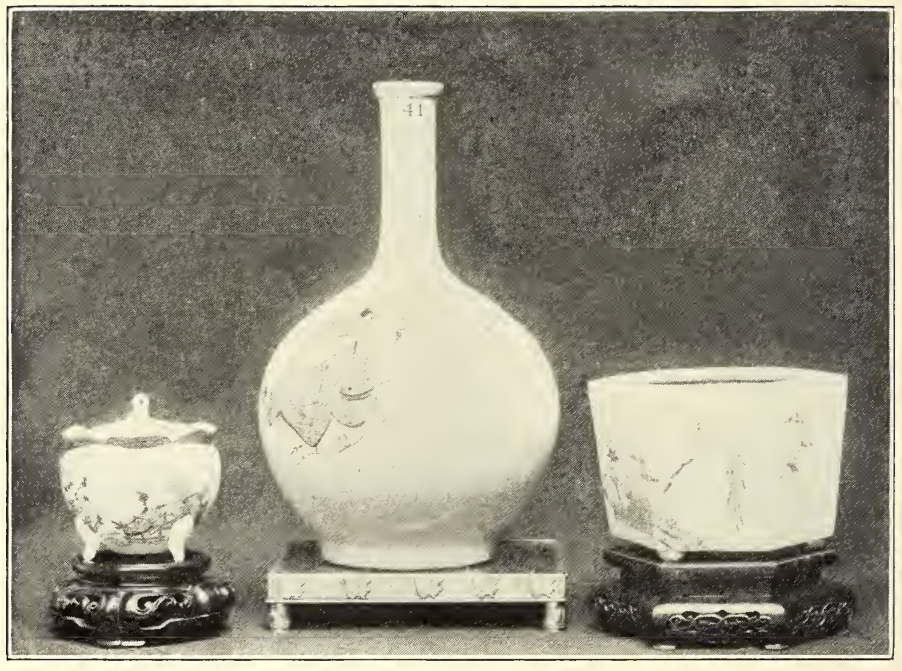

No. 39 .

No. 4I.

No. 40 . 
40 Bowl. Decoration, Japanese pheasants, pine and cherry tree in blossom. Date, I620. With teakwood stand. Height, 3 I-2 inches.

4 I Bottle; design, monkey and monkey charmer. Genuine work of Kakiyemon Arita. Date, I650. Teakwood stand. Height, ro inches. (See illustration.)

42 Gold Lacquer Tray. Decoration, bush clover near brook. Partly inlaid with Mother of Pearl; leaves and rocks inlaid in gold. Stream finished in Togidashi or polished lacquer. Made by Kagikaya. Date, I 780 .

43 Red and Gold Lacquer Chest. Decoration, "Seven Wise Men of Bamboo Forest." Two hundred years old.

\section{NOTE.}

Okumura Shozan, Modern Kenzan, as he is called, is about sixty years of age, living near Teapot Hill, Kioto. He has unrivalled talent in copying famous Ninsei and Kenzan. The peculiar blue which none can imitate is known as "Kenzan" Blue. He attends to his work in every detail, hiring no assistants, as do most other potters.

44 Shozan Jar. Decoration, Japanese native iris in Kenzan blue. Beautiful crackle. Height, Io inches. Diameter, 9 I-4 inches.

45 Jar with cover. Unique form; decoration, storks in gold and silver. By Shozan. Height, 8 I-2 inches.

46 Vase. Decoration, shells and seaweed painted in Gosu blue under the glaze. Height, 5 I-2 inches.

47 Vase. Decoration, iris in blue and white on mirror black ground. By Shozan.

48 Mulberry wood Tray, shape oblong. Carved monkeys by Sessai, Miyajima. Diameter, I 5 inches. Signed. 25 X I 7 I-2 inches.

49 Large Shigaraki Tea Jar. Rich Namako glaze covers conventional peony design in relief. Height, 32 inches. 
50 Porcelain Vase, made by Shimidzu, Nagoya. Decoration seventy-five varieties of royal chrysanthemum in different colored enamels. The neck of the vase has beautiful border of butterflies. Height, I 6 inches.

5 I Ivory Carving: "Travelling Priest Attacked by Crabs." Height, 5 I-2 inches.

52 Ivory Carving: "Mask Carver."

53 Ivory Carving: "Japanese Painter Frightened by Mouse."

54 Ohi Bowl; green and yellow glaze over brown body. Fine specimen. Mark, Ohi. Date, I780.

55 Kioto Tea Bowl, known as Kioto Soma. Decoration, two horses painted in blue under glaze.

56 Kishiu Bowl, in form of bamboo trunk. Purple and blue glaze.

57 Small Wooden Cabinet. Front finished in burnt cedar with bronze ornaments. Height, I 6 inches; depth, I I inches; length, 23 inches.

58 Shozan Vase. Made by Okumura Shozan, celebrated Kioto artist. Decoration, iris on mirror black ground.

59 Old Oribe Hibachi. Splash of pale blue glaze on warm gray ground. Conventional design about body of hibachi. Very old specimen. Date about I 700.

60 Old Temple Bell. Handle in form of tokko. Used in Buddhist temple during religious ceremony. Melodious tone. Date, 1650.

6I Bronze pitcher with cover. Fine repousse. Date, I650.

62 Ofuke Flower Pot. Conventional pattern painted in rich dark blue under glaze. Made in Province of Owari. Height, I 2 inches.

63 Takatori Jar with flaring diamond shaped top. Rich mottled glaze over soft brown. Mark, Taka and kiln mark. Date, I 800. Height, 7 inches. 
64 Kenya Vase. Decoration, conventional design in blue and green enamel. Date, I8 IO. Height, 5 inches.

65 Old Imari Plates (seven pieces). Dragon and peony painted in blue under glaze. Each plate bears marks of pins upon which it rested in the kiln as was the custom in firing about 1680 to 1750 .

66 Yellow Bronze made by Gorosa of Kioto. Height, I 2 inches. With teakwood stand.

67 Old Bronze Vase. Beautiful olive green. Date about I 700. Height, I I inches.

68 Old Chinese Bronze Vase. Shape, round, narrow in neck. Fine specimen of Hsuang-Te ( I 426). Height, 8 inches.

69 Chinese Celadon. Yang-ching Period ( I 723). Color, beautiful tea-green. Teakwood stand. Height, I6 inches.

70 Old Bronze Vase, treated by Mitsuhiro. Beautiful form and superb color. Height, 6 inches.

7 I Old Shigaraki Bottle. R'are specimen. Height, 9 I-2 inches.

72 Old Yatsushiro Hanging Vase. Melon shape, clear cut white stripes coming half way down the vase. Beautiful blue gray. Made at Matsushiro, Hizen, about I 780; has oldest mark. Mark, "Gen" in double ring. Height, 7 inches.

73 Old Yatsushiro Incense Burner. Graceful form of Koro with beautiful curved ears. Clear white peony inlaid on clay. Cover perforated in conventional pattern. With teakwood stand. Height, 5 I-2 inches.

74 Banko Bottle. Bamboo green glaze. Decoration, fish in water under waterfall. Height, 8 I-2 inches.

75 Hagi Bowl. Irregular oval shape covered with a gray glaze slight tinged with pink. Made by Koraizaye mon. 
76 Shozan Jar. Floral decoration in Kenzan blue. Made by Okumura Shozan.

77 Enamel Vase. Decoration, blossoming plum tree on bank of stream in which ducks are swimming. Ground color beautiful tea-green. Unusual specimen by Honda of Nagoya. Height, I 2 inches.

78 Pair of Enamel Vases. Decoration, duck in the moonlight. Beautiful gray enamel. Autumnal sky produced with great skill. These vases were purchased by the collector at Kioto Exhibition I 895. Made by Hattori of Nagoya. Received highest award at the Exhibition. Height, 7 inches.

79 Cloisonne Jewel Box. Decoration, dragon and floral design in various colored enamels.

80 Enamel Vase. Foundation is of silver. Decoration, Fugi Mountain and storks in flight. Made by Hattori of Nagoya. Height, 6 inches.

8 I Chinese Porcelain Vase. Ching-lung Period (I 736). Rich red and blue Shinsha glaze covers peach tree carved in relief under the glaze. With teakwood stand. Height, I I inches.

82 Old Purple Satsuma Vase. Tall, cylindrical shape, flaring at top. Glorious purple glaze covers the entire vase; richly irridescent. The vase was made for use at chief castle of Lord Shimadzu. Very little real purple Satsuma was ever made, but many imitations have been produced recently. This signed specimen is one of the finest in existence. Inscription on bottom ("Made by Tateno for use at head castle"). Date about I750. Height, 24 inches. (See illustration.)

83 Plain White Satsuma Vase. Form, hexagonal with long slender neck. Genuine old specimen. Date, I 750 .

84 Awata Bowl. Chrysanthemum decoration. Mark, Tozan. Height, $6 \mathrm{I}-2$ inches. Diameter, Io inches. 


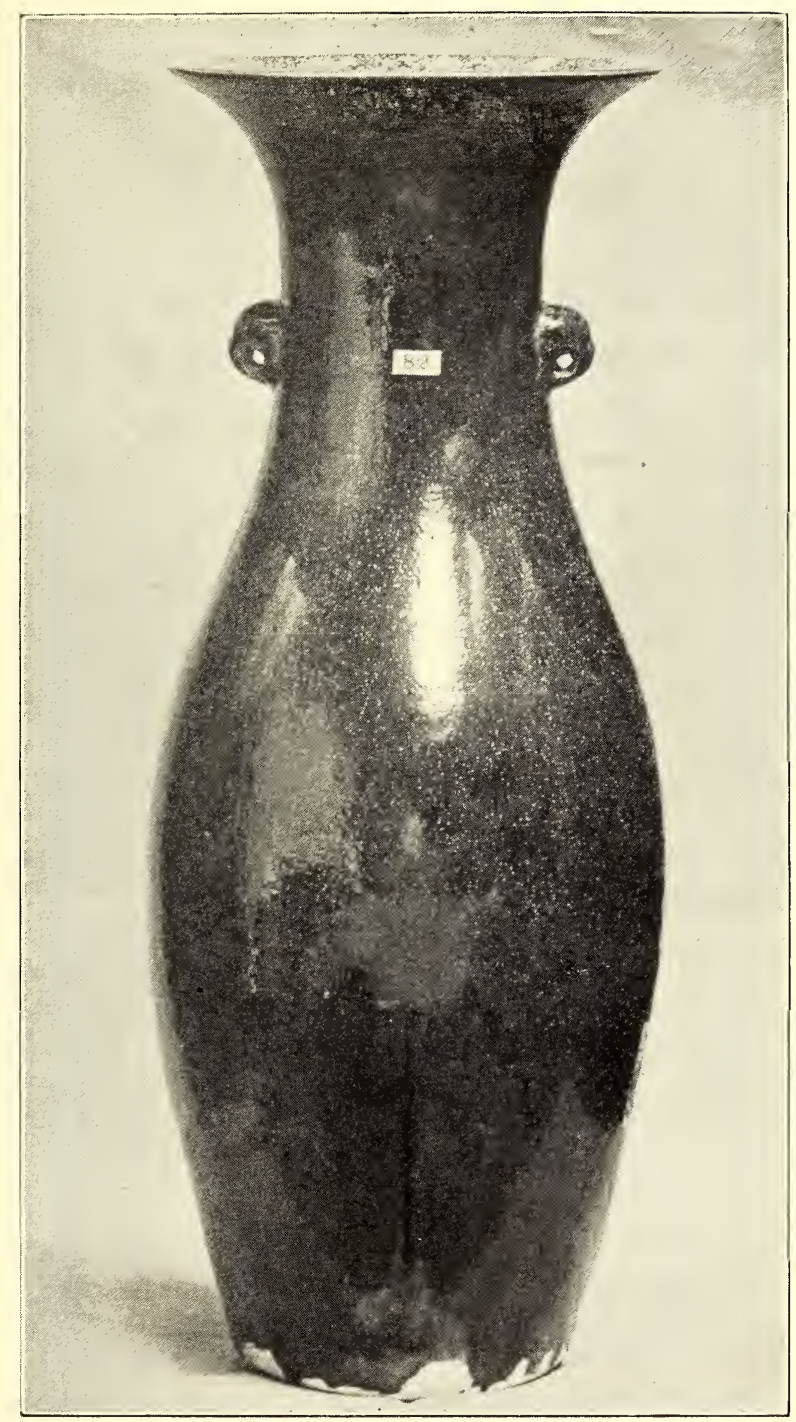

No. 82 . 

85 Tamba Bottle. Splash of bluish white and light brown on dark brown ground. Remarkably fine specimen. Date, I 700 .

86 Takatori Dish, in form of flower. Old specimen. Date, 1725 .

87 Seto Jar. Rich reddish brown glaze.

88 Awata Jar with cover. Made by Shozan. Decoration, red plum tree in blossom. Height, 7 I-2 inches.

89 Arita Porcelain Vase. Design, gold fish and water grass. White gold fish are carved in relief under glaze. Fine specimen.

90 Old Imari Bottle. Square, with sacred dragon and phœnix painted in blue under the glaze. Rare specimen. Height, 7 I-2 inches.

9I Shrine of Amida Buddha. Old gold lacquer lined shrine with six Amida Buddha carved from white sandal wood. Date, I 700 .

92 Shrine of Kwan-non. Standing figure of Kwan-non is cast in bronze. Lotus flowers and leaves are of fine yellow bronze. Shrine finished with gold lacquer.

93 Bronze figure of Dramha. Chiselled by Tosai. Date about i 7 I 8 .

94 Bronze Buddha. Made during I 5 th Century. With teakwood stand.

95 Bronze Vase. Design, dragon supporting vase; made by Shimasa of Osaka. Height, I 8 inches.

96 Incense Burner. Decoration, quail in chrysanthemum garden, painted in relief with enamel. Group of mice carved out of clay. Made by Hansuke of Ise.

97 Three mice carved out of clay, by Hansuke. Height, 6 inches.

98 Two White Mice. Carved out of Clay by Hansuke.

99 Awata Sake Bottle in form of gourd. Decoration, peony blossom in blue and green enamel. One of the oldest Awata specimens. Date, I 700. 
I Oo Bronze Hibachi. Beautifully mottled red and brown surface. Conventional design carved out around edge. Handles represent head of elephant. Height, 7 inches. Diameter, Io inches.

I I Iron Garden Lantern. Hexagonal in form, with colored art glass. Has iron chain.

IO2 Wooden Lantern with iron chain; hexagonal. Used in Japanese garden.

I03 Old Imari Plates. (Two pieces.) Decorated with beautiful pattern in coral red and green enamels. Date, I 780.

I04 Old Imari Plates. (Six pieces.) Bamboo trees are painted in blue and gold; wreath of chrysanthemums in coral red in the centre.

I05 Old Imari Plates. (Five pieces in set.) Lamb in pasture painted in blue under glaze. Date, I 720 A. D.

Io6 Kioto Jar. By second Dohachi. Branch of pine painted on ivory yellow ground. Has mark, "Ninami", in shell. Height, 7 inches.

I07 Imari Plate. (Five in set.) Dragon and Phonix decoration in gold over coral red and under blue stripes. Charming peony design in centre.

Io8 Cake Dish. Celadon green; made by Gozayemon, about i 760 .

Io9 Chinese Porcelain Vase. Bird and floral design carved in relief and painted in green and brown enamel. The body of the vase is in the form of a bamboo trunk, royal yellow in color. Made in Yang-ching Era ( I 72.3). With teakwood stand. Height, I I inches.

I IO Pottery Compartment Box. Beautiful glass pattern painted in blue under glaze. It is very rare and delicate work. Probably made by Kenzan about I 730 . 
I I I Old Kioto Dishes. (Three in set.) In form of open fan. Mark Udzura Yama.

I 2 Red Raku Bowl. Beautiful specimen of hard Rakuabout i 75 o. Mark Yu.

I 3 Satsuma Teapot. Conventional pattern in black on bluish gray surface. Known as "Sunkoroku." Rare specimen. Date, i 700.

I 4 Awata Teapot. Spray of flowers in relief, painted blue and green. Old specimen. Date, I 700.

I 5 Kishu Teapot. Made at Kwairakuyen, Kishu. Splash of purple and blue glaze. Old specimen. Date, I 780 .

I 6 Wine Pot by Taizan of Kioto. Used in wedding ceremony. The cover is made different purposely.

I 7 Toyoraku Cup Stand. Made by Second Toyoraku. $\mathrm{Rim}$ of stand is red lacquer with decoration of Fugi Mountain in gold. Date, I 800 A. D.

I 8 Bronze Incense Burner, in shape of lotus flower and seed pod. Five Sanscrit letters on the cover. Height, 9 inches. Date, about I 700.

I 9 Porcelain Hanging Placque. Moonlight and weeping willow. Made by Joho of Nagoya. Length, i 8 inches.

I 20 Chinese Enamel Dish. Square; decoration, pommegranate and conventional grass in green enamel on deep blue ground. Has mark on bottom. Date, i 780 .

I 2 I Old Bronze. Diameter, Io inches; height, 7 I-2 inches. Date, I650.

I 22 Bronze Vase, flaring top. Very fine quality Height, 9 inches. With teakwood stand.

I 23 Bronze Kettle. Made by Nagoshi. Very fine quality. 


\section{CABINET OBJECTS.}

I 24 Old Hirado Teapot and stand. Date, I 720.

I 25 Incense Box made at Awata, Kioto. Fine Crackle. Mark, Iwakurazan.

I 26 Banko Vase. Made by Yusetsu. Beautiful specimen.

I 27 Old Bronze Teapot. Made in Seventeenth Century.

I 28 Incense Box. The body of box is in form of a rock made of Shakudo, maple leaves inlaid with gold. Cover of box three turtles swimming in water, lined with solid silver. Made by famous worker in metal, Kongosai. Signed.

I 29 Kioto Teapot made by Mokubei. Beautiful purple, yellow and green glaze. Date, i 800 A. D. Mark, Mokubei on cover. Genuineness guaranteed.

I30 Drinking cup made by Second Kenzan. Beautiful grass pattern painted in blue and yellow.

I 3 I Maizan Satsuma Jar with cover. Delicate illustration of Child Life in Japan. With teakwood stand.

I 32 Hagi Jar. Cloudy pinkish glaze. Very rare.

I33 Maizan Satsuma Vase. Decoration, illustrating Japanese Tea Party. Upper and lower portion of vase has decoration in gold on dark blue ground. With teakwood stand.

I 34 Old Hirado Duck. Incense Burner. With teakwood stand.

I 35 Maizan Satsuma Vase. Smallest made by Maizan. Decoration, illustrating Japanese school. 


\section{ORDERS EXECUTED WITHOUT CHARGE.}

\section{Second Day's Sale-Friday, April 22, at 3.}

I 36 Porcelain Placque. Full moon and clouds in Spring sky. Superb work of Shimidzu Rokunosuke. It is altogether marvellous to produce such a masterpiece of work on porcelain in one color. His decorative talent eclipses all Japanese "Cloisonne" makers. Size I 3 inches x I 8 inches.

I 37 Kioto Vase; cylindrical, conventional Mokko design in green and black. Fine old specimen. Height, I I inches. With teakwood stand. Date, I750.

I 38 Hirado. Dishes. (Six pieces.) Decoration, three gourds painted in red, blue and yellow under the glaze.

I39 Kutani Bowl; square, decoration in gold over dull red. Fine old specimen. Date, I 700.

I 40 Large Soma Bottle in form of gourd. Upper half covered with rich mirror black glaze; lower part covered with rain-drop brown glaze. Made at Nakoso in Province of Hitachi. Height, I 4 I-2 inches. Date, I 700. Rare specimen.

I 4 I Seto Bowl; beautiful crackle. Has a great resemblance to Shun. Made by Shuntai. Mark, Koki Shuntai. Date, i 780.

I42 Karatsu Jar. Beautiful blue glaze over rich brown. Unusual specimen. Made about i680.

I 43 Old Bronze Vase; four sided with long narrow neck. Beautiful green bronze, preserved from Fifteenth Century. One of the most important bronzes in the collection. Height, I 2 I-2 inches.

I 44 Bronze Vase. Beautiful smooth surface, handles in form of elephant's head. Height, 5 I-4 inches. Date, 1750 . 
I 45 Old Green Bronze. Cloudy red on deep green; conventional border. Heads of two imps form handles. Height, 7 3-4 inches. Date, I700. Rare specimen.

I 46 Kioto Jar. Decoration, royal chrysanthemum crests on green. Made by First Taizan. Very rare specimen. Height, Io inches. Date, I 730.

I 47 Figure of Kwan-non. Represents Juichimen Kwannon or Eleven Headed Goddess, gracefully posing on a rock. It is a magnificent piece of carving and gold lacquer work by a master hand. Beautiful Jines and color of her drapery and the expression of profound dignity add a perfect splendor. A precious jade stone is inlaid in the forehead of the figure. The rock is natural white sandal wood. Made about 1550 . Height, 8 inches. (See illustration.)

148 Kosobe Sake Bottle. Floral decoration painted in blue. Made in Kosobe in Province of Setsu. Height, 9 inches.

I 49 Seto Jar; hexagonal, with marvelous Tenmoku glaze on rich brown running uniformly over the jar. This was known as "Rabbit's Hair Glaze," and is one of the rarest specimens ever produced in kiln. It is decidedly a lost art and now only happens by accident. Made by Gosuke of Seto. Height, I 3 inches. With teakwood stand.

I 50 Owari Dish; square, decoration of plum tree in blossom in black. A thin ecru glaze covers the whole dish. Maker unknown. Date, I 750.

I 5 I Old Kutani Vase. Gold and silver decoration on rich coral red. Magnificent specimen of old Kutani Height, 6 inches. With teakwood stand.

I 52 Shozan Jar. Decoration, mass of poppies in red, pink and Kenzan blue. Beautiful crackle. Diameter, 9 inches; Height, ro inches. 


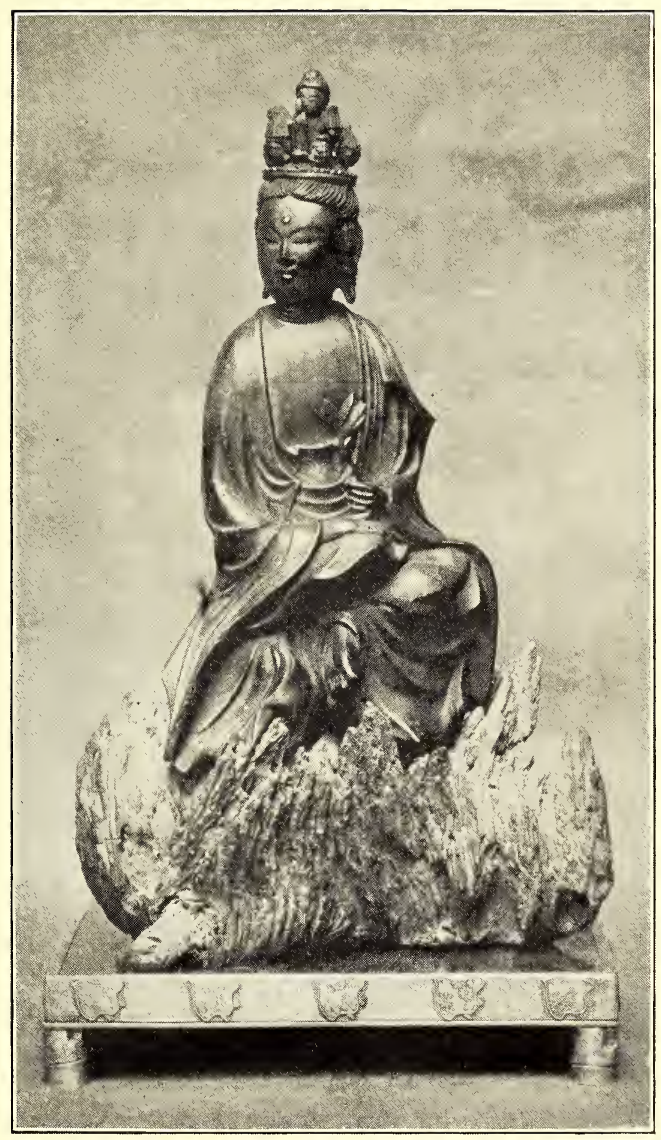

No. 147 . 




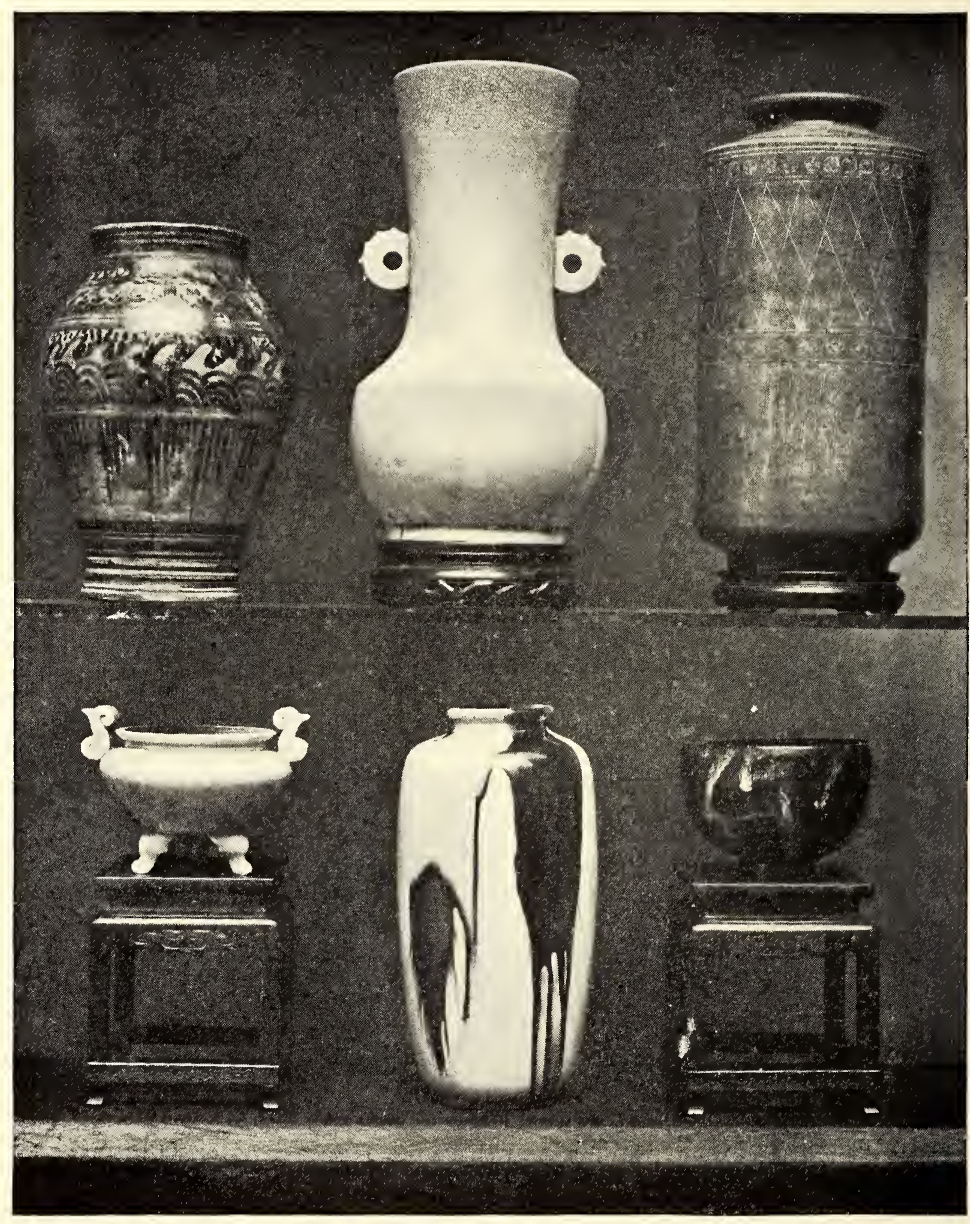

No. 156 .

No. 157 .

No. 153 .

No. $15^{8}$.

No. 155 .

No. 154 . 
NOTE.

Satsuma Faience. Satsuma Ware is perhaps better known in this country and in Europe than any Japanese pottery. But only one kind is familiar - that of a finely crackled glaze decorated elaborately in gold and rich colors. Of the other kinds a very little seems to be known.

Among the many kinds to be found in Satsuma are Mishima Satsuma, Bekkode Satsuma, Seto Kusuri Satsuma, Chosa Satsuma, Sunkoroku Satsuma, Torafu Satsuma, Ibo Satsuma - all very rare and valuable. Early specimens of these are those of the Sixteenth Century after many skilful Korean potters were brought back by Prince Shimazu when the triumphant return of 'Taiko's Korean Expedition was made.

I 53 Mishima Satsuma Vase; cylindrical shape. Old and rare specimen of Mishima; beautiful gray glaze. Delicate decoration of light gray stripes and band inlaid under the glaze. Date, I 70o. Height, I I inches. With teakwood stand. (See illustration.)

I 54 Seto Kusuri Satsuma Bowl. Bluish Seto glaze over rich brown. Beautiful form ; unusually fine quality. Date, i $800 . \quad$ (See illustration.)

I 55 Torafu Satsuma, known as Tiger Skin Satsuma. Splash of rich yellow and purple glaze on fine crackled surface. Very rare specimen. Height, Io inches. Date, Isoo. With teakwood stand. (See illustration.)

I 56 Sunkoroku Satsuma Vase; so called from the fact that it was made after the style of Southern Chinese ware. Yellowish gray glaze over dark archiac designs. Date, r 720. Teakwood stand. Height, 9 inches.

I 57 Muzi Satsuma Vase. Plain white Satsuma. Rich creamy color, fine hard crackle. Beautiful old specimen made at Nayeshirogawa in the Province of Satsuma. Date, I 750 . Height, I 2 inches. (See illustration.) 
I 58 Muzi Satsuma Bowl. Very fine crackle and finest quality. Inscription on bottom: "Third Year of Bunsei Era," ( I 82 I.) Satsuma Tateno. Height, 5 inches. (Seeillustration.)

I 59 Sunkoroko Satsuma Vase. Conventional wave pattern painted in dark brown over gray ground. Unique form. Height, I 3 inches. Date, I 730.

I60 Large Shigaraki Jar. One side covered with streaks of beautiful green glaze, the other with splashes of soft blue. Used as a tea jar by wholesale tea merchants in Kioto. Remarkably fine piece made at Nakano Village of Shigaraki about I 700. Height, I 3 inches.

I6I Old Brocade Screen (four fold). Each panel 20 inches wide and 60 inches high. Valuable collection of brocades mounted on each panel.

I62 Buzen Jar; dark tea colored glaze. Thick white glaze covers rim marked here and there with splashes of green and gray. Height, 6 inches. Date, I750.

I63 Bizen Jar. Decoration, bamboo and pine tree in black glaze on brown unglazed surface. Height, 6 inches. Date, I 750 .

\section{KAKEMONO.}

I64 Pair of Kakemono by Soami. Famous painter of Fifteenth Century. Birds and flowers painted in India ink.

I65 Kakemono by Motonobu. Subject, "Eagle." Date, 1548 .

I 66 Kakemono by Sosen. Subject, "Two Monkeys." Silk mounting. Date, I820.

I67 Kakemono by Tankio. Subject, "Japanese Native Peony," painted on silk with silk mounting. Date, I 840 . 
I68 Kakemono by Kano Tanyu. Subject, "Bird on Branch of Tree." Silk mounting. Date about 1660.

I69 Kakemono by Raisho. Subject, "Futami Rock and Fugi Mountain." Painted on silk with silk mountings. Famous Shijio School painter. Date, I 840.

I 70 Kakemono by Giokuho. Subject, "Plum Tree and Nightingale." Unusual work. Painter from famous Shijio School. Date, I 840.

I 7 I Porcelain Vase; dragon and Fugi Mountain painted in blue under the glaze. One of the finest modern porcelains by Kamamoto, in Province of Owari. Height, I 3 inches.

I 72 Green Bronze Hanging Gong; used in temple. Beautiful tone.

I73 Old Mino Jar. Splashes of brown and green glaze on cream white ground. Height, 8 inches. Date, I 800 .

I74 Old Hirado Porcelain Vase. Decoration, landscape and poetry painted in gold on dark blue ground. Height, 8 inches. Date, I740.

I 75 Old Carving; pine tree and storks. Finished on both sides. One hundred and fifty years old. Size, I 4 I-2 inches $\times 37$ inches.

I 76 Old Carving; two ducks swimming in water. Came from old temple at Nara, and is over 500 years old.

I 77 Old Bronze Bowl made by Nagoshi, the famous Kioto bronze maker. Height, 7 inches. Diameter, 8 inches. Date, I 750.

I 78 Old Bronze Kettle; tall, cylindrical shape; fine quality. Date, I 780.

I 79 Bronze Vase; cylindrical. Has partition in centre so that it can be used either way. Fine red and green mottled coloring. The bronze is of a fine quality and about 400 years old. Height, 9 I-2 inches. 
I 80 Old Iron Teapot; spherical, corrugated body. Cast by Yamashiro, famous Kioto bronze maker of Seventeenth Century. Has exquisite wooden cover representing a worn out Japanese farmer's hat with a toad seated upon it.

8 I Ivory Carving; "The Hunter." Figure represents Japanese hunter returning from hunting expedition. His game-a heron-is hung over his shoulder on a stick. The straw hat and straw-mat leggins, the smoking pouch on his hip and old Japanese firearm are carved with great care. It is one of the most graceful and interesting carvings ever seen ; carved from a single piece of ivory and measures seven inches in height. Awarded medal at Tokio Art Association, I 897. Carved by Mitsuhiro; signed. Has lacquered stand with silver trimmings. (See illustration.)

I 8 I $1 / 2$ Ivory Carving; Lioness Making Ready to Jump. Wonderfully well carved by Rivmin, Tokio.

I 82 Ivory Carving; Wise Man Reading Scripture and Three Monkeys Eating Peaches. Carved by Giokmyn of Osaka. Height, 3 inches.

I 83 Ivory Carving; Boy Playing with Monkey. Monkey is begging apple from the boy. Beautiful little carving.

I 84 Ivory Netsuke; Two Mice Eating Cakes. Carved by Giokushin.

I 85 Ivory Carving; Card Box. Decoration on cover, monkey holding insect carved in relief. By Shoichi of Tokio.

I 86 Old Hirado Dish. Decoration, two wine jars in rice field painted in exquisite blue under glaze. It is a very rare specimen of oldest Hirado. Date, I 700 A. D.

I 87 Oid Imari Dish. Three gourds and leaves painted in blue under glaze. Most delicate blue ever made in Imari. Date, I 750. 


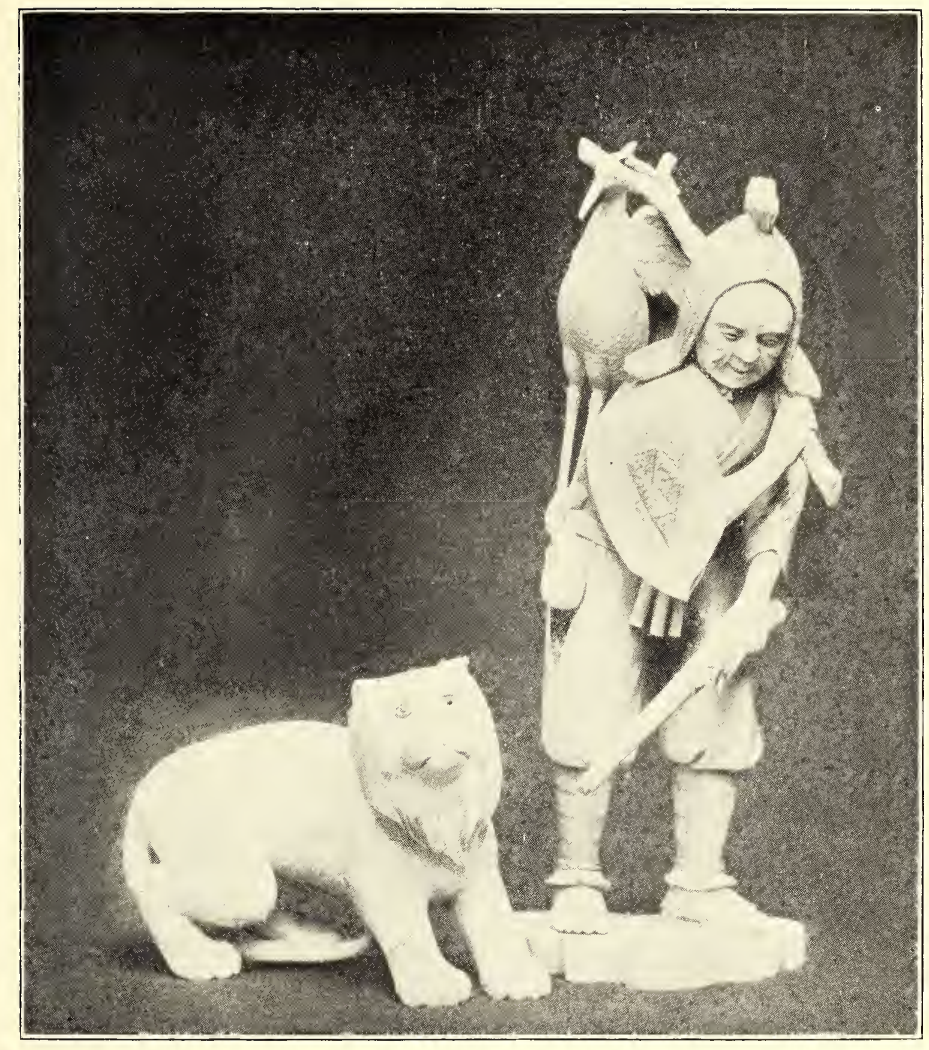

No. 18I. 

I 88 Old Imari Plate. Decoration in various colored enamels and gold. Date, I 800.

I 89 Plain Satsuma Platter. Genuine old piece, fine crackle. Mark Giokuzan. Date, I 780 .

I90 Takatori Bottle. Irregular form, narrow at neck. Beautiful yellow and white mottled glaze on neck and shoulder of bottle. One of most brilliant specimens of Takatori ware in collection. Date, I 750.

I9I Pottery Vase; Agano in Province of Bizen. Splash of deep blue on crackled gray ground. Has mark "Ho." Date, I 750.

\section{FINE TEA BOWLS.}

I92 Raku Tea Bowl; made by Ninth Raku. Beautiful ecru glaze. Date, i 820 A. D.

I93 Raku Bowl, made by Seventh Raku. Remarkable red with cloudy black marking on one side. With original box. Fine specimen. Date, I780.

I94 Raku Bowl. Mirror black with cloudy red glaze. One of the most glorious specimens by Seventh Raku. Signed.

I95 Oribe Bowl; beautiful gray glaze dotted with black. Finest quality of Oribe ware. Made about 200 years ago.

I96 Shidoro Bowl, made in Province of Totomi. Yellowish glaze over corrugated surface. Beautiful specimen.

I97 Kioto Tea Bowl; beautiful pink and gray glaze. Border of Mishima pattern about the bowl. Peculiar irridescence. Date, I730.

I98 Awata Tea Bowl; cylindrical, conventional grass pattern painted with yellow and blue glaze in relief. Rare specimen. By Giozan, Awata. Date, I 750. 
I99 Tea Bowl; corrugated surface covered with thin gray glaze. Made in Province of Yamashiro. Mark, Asashi.

200 Awaji Vase; elliptical. The entire surface of vase is covered with spots of white enamel inlaid on red ground. Beautiful specimen. Signed Mimpei. Height, I 3 inches.

20 I Sanuki Dish in form of basket; green and yellow glaze. Has perforated rim. Old specimen made by Shido Shunnim, about I 740. Height, 4 inches.

202 Takatori Bowl with nose; smooth gray glaze over beautiful amber brown. Date about i 800 .

203 Shozan Jar. Charming decoration of poppies and hydrangea in various delicate enamels painted in relief. Beautiful Satsuma crackle. Made by Okumura Shozan, famous Kioto potter. Diameter, $8 \mathrm{I}-2$ inches. Height, $\mathrm{I} 0$ inches.

204 Banko Dish. Glorious green glaze; rabbit and rice mortar painted in the centre. Made by Yusetsu about i 830 A. D.

205 Satsuma Vase; square, with Chinese poetry carved in relief on the four sides. A most attractive piece made by Chinjukan of Satsuma. Awarded medal at Kioto Exposition in 1895. Signed Satsuma Chinjukan. Height, I 4 inches.

206 Teakwood Tray in form of banana leaf. Carved from one piece of wood. Length, 36 inches.

207 Kinuta Celadon Jar. Figures of three children playing about the rim. This truly magnificent specimen of Celadon was made at Arita in the kiln of Prince Nabeshima about I 700 A. D., and is known as Kinuta Seiji or Silk Celadon. The charming soft green of uniform brilliancy surpasses any Chinese Celadon. One of the most wonderful porcelains $\epsilon$ ver produced in Japan. In spite of its age of nearly two centuries the jar is as fresh and clean as if dew were dropping from its silky surface. One of the most important objects in the collection. Height, 8 inches. Has solid silver cover. (See illustration.) 


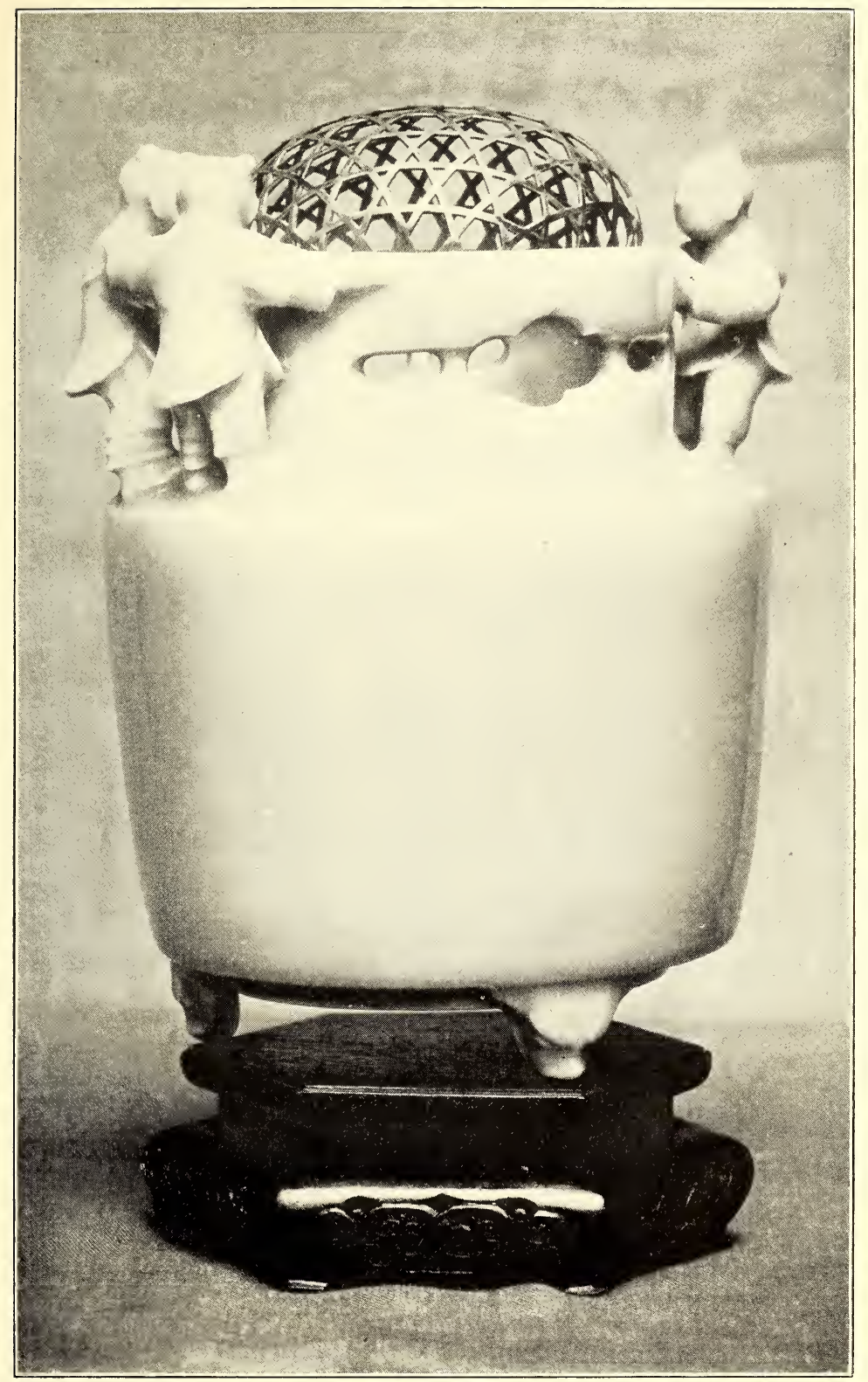

No. 207. 

208 Oribe Dish with Handles. Irregular form with pinkish gray glaze painted a little with black. Rare specimen. Date, 1750.

209 Satsuma Teapot; diamond shape. Decoration, scene from Japanese life. By Maizan.

2 Io Satsuma Bowl. Decoration inside, cherry blossoms in Kioto and several celebrated scenes painted on the folds of a fan. Outside has gold brocade pattern. Made by Maizan.

2 I I Satsuma Cup and Saucer. Exquisite in design. Decoration, Royal Procession of Mikado. By Maizan.

2 I2 Satsuma Vase. Four panels decorated with scenes from Japanese Life. With teakwood stand. By Kozan.

2 I 3 Satsuma Vase. Decoration, Japanese children's party, painted with great care. Has tiny teakwood stand. By Kozan.

2 I4 Seto Vase; beautiful form. Green and blue glaze over gray. One of the oldest specimens (about 400 years old.) Height, Io inches. With teakwood stand.

2 I 5 Banko Tea Bowl; brown and gray glaze. Genuine old specimen. Date, I 750.

2 I6 Kioto Vase; upper portion covered with rich green glaze. Rare specimen made by first Kinkozan. Height, 7 I-2 inches.

2 I 7 Celadon Incense Burner. This beautiful piece was made at Nabeshima and known as Kinuta Celadon. Graceful form and fine color. Teakwood stand. Height, 4 inches.

2 I 8 Yellow Bronze Jar. Fine quality of bronze; made in Bunkwa Era (I 804). Height, 7 inches. With teakwood stand.

219 Green Bronze Vase; lizard curling about the neck. Made by Mitsuhiro, Tokio. Height, I I inches.

220 Repousse Kettle. Made by Nagoshi. Date, I750. 
22 I Bronze Plate, known as Scarlet Bronze. Beautiful glowing red on one side. 200 years old.

222 Ofuke Pottery Vase; tall, corrugated surface covered with rich yellow glaze gradually changing to a deep blue. Crab carved in relief under the glaze. Made in Nagoya, Owari, about I 700. Most important Owari specimen in the collection. Height, I 3 I-2 inches.

223 Kioto Dish (two pieces). Beautiful floral decoration in blue covered with green glaze. About roo years old.

VALUABLE JAPANESE SWORDS.

224 Japanese Sivord; length of blade 28 inches, carved with shield of God of War. Very fine quality of steel. Hilt of shark's skin wound with whalebone, ornamented with Menuki carved in gold. Guard is of iron ornamented with "tossing waves carved in relief inlaid with gold." Made by famous metal worker, Shiganaga of Harima. Scabbard is of gold lacquer with celebrated crest of three interlying squares inlaid with Mother of Pearl. This sword was formerly in the possession of Danjuro the Eighth, the renowned Japanese actor, about I830. The blade is about 400 years old.

225 Short Sword. Mate to one above.

226 Court Sword; length of blade 29 inches, fine quality of steel. Scabbard is gold lacquer work throughout. Sivord guard and hilt mounted with gold ornaments.

227 Japanese Sword; length of blade 32 inches, carved with sacred dragon. Finest steel blade preserved in simple white wood case. A very important sword; the blade about 300 years old. 
228 Short Sword by Masamume. Length of blade I 4 inches. Beautiful vapor-like mark on steel result of his famous method of forging. Genuine work of Masamume Okazaki of the Fourteenth Century.

229 Sword Rack. Red lacquer work known as Tsuishu, carved with elaborate design of ancient warriors.

230 Hirado Porcelain Vase; cylindrical; lotus flowers and birds painted in blue under the glaze. One of the oldest and finest specimens of Hirado in the collection. Height, 16 inches.

23 I Old Karatsu Jar. Upper portion covered with beautiful bamboo green glaze; lower part a rich seal brown. 400 years old.

232 Hagi Vase; cylindrical, with long ears. Opal gray glaze over corrugated surface. Height, 7 inches.

233 Large Shigaraki Jar. Marvellous Namako blue glaze covers the entire jar. Made at Namakura in the Province of Omi. Height, 37 inches.

234 Scripture Cabinet. Red and gold lacquer trimmings and repousse metal ornaments. Beautiful carving of chrysanthemums and leaves lacquered with gold about the top of the cabinet. Taken from Buddhist temple. Height, I 6 inches; width 26 I-2 inches. Date, I 725 .

235 Large Water Kettle; by Nagoshi of Kioto, celebrated Court Bronze Maker. Quality of bronze like that of Shakudo; perfect in every detail. Date, about I 780 .

236 Silk Embroidery; Sacred Dragon and turtle embroidered with real gold thread on navy blue satin. The back of the turtle is specially worthy of mention. Has silk brocade border. Size, 6 feet 7 inches $x 4$ feet.

237 Bottle; beautiful Ruri blue with delicate pale blue mark. Made in Arita. Height, I 2 inches. Date, I 700 .

238 Shozan Vase; design, iris painted in relief with various colored enamels. Height, I I inches. 
239 Banko Jar with cover. Spray of chrysanthemum painted under the glaze. Beautiful crackled gray glaze, reminds one at once of finest quality of Awata. Very interesting specimen. Height, 7 I-2 inches.

240 Idzume Bowl; irregular form, deep bronze yellow. Made at Saki Province of Idzume. Date, I 730.

24 I Porcelain Bowl; glorious Ruri blue. Made in Owari about I680. Beautiful specimen.

242 Kenzan Dish; square, design, moon and grass. Genuine work of Kenzan. Signed.

243 Chinese Stone Ware Vase; eliptical; rich tea green glaze. Kang-hi period, I662. This has been one of the treasures of the famous Samurai of Saga in the Province of Hizen, who, after the Imperial Restoration, I867, moved to Kioto, where he was obliged to dispose of his collection.

It is interesting to remind the connoisseur of the fact that Nagasaki had been the only port open to foreign trade for the past three centuries, and was mostly monopolized by Dutch and Chinese traders. Rare specimens of Chinese Fine Arts were often brought across the water, and this vase was among those early importations from China, much sought after by Daimyos of Kiushu. Indeed this is one of the most attractive Chinese objects in the collection. With teakwood stand. Height, 9 3-4 inches.

244 Shozan Jardiniere; decoration, Japanese native peony painted in blue, white, green and red enamels. One of the most beautiful specimens of work by Okumura Shozan. Height, 8 inches; diameter, Io inches. 


\section{CABINET OBJECTS.}

245 Bronze Cup in form of Boat; Ioo years old. With original box.

246 Tanzan Vase; beautiful purple glaze.

247 Two Turtles; pottery, made by Yashima Rinso. Date, I 820 .

248 Ohi Vase; beautiful irridescence. Ioo years old.

249 Blue and White Cup; beautiful crackle. I50 years old.

250 Takatori Jar, beautiful white glaze. I 50 years old.

25 I Bizen Bottle. Rare specimen.

252 Porcelain Bottle. Decoration, fifty varieties of chyrsanthemum.

253 Miniature Satsuma Vase. With teakwood stand.

254 Miniature Satsuma Vase. With teakwood stand.

255 Banko Celadon Incense Burner.

256 Old Satsuma Dish (six pieces). Quality like ivory. I 50 years old.

257 Beautiful Miniature Bronze Vase.

258 Gold Imari Dish (five pieces). Decoration in old blue and coral red. 200 years old.

259 Takatori Bucket; beautiful glaze.

260 Miniature Black Satsuma Vase. Decoration, Sacred Dragon in gold.

26 I Celadon Cup; three turtles crawling out of the cup.

262 Miniature Metal Wine Cup. Beautifully carved with conventional grass pattern.

263 Porcelain Hanging Panel. Decoration, cherry blossoms and moon. Painted by Joho. Charming piece. 


\section{ORDERS EXECUTED WITHOUT CHARGE.}

\section{Third Day's Sale-Saturday, April 23, at 3.}

264 Old Wood Carving; Sacred Dragon carved in bold relief. This was the centre piece over the threshold in an old temple in Yeichigo. (Pair of carvings on either side representing Phœenix were purchased by Boston Museum of Fine Arts. This is one of the most important wood carvings of early part of Eighteenth Century.) Length, I 2 feet 6 inches; height I4 I-2 inches; depth 8 inches. Date, i 720.

265 Old Wood Carving; Lion's Head. Part of upper portion of pillar in Temple at Nara. 300 years old.

266 Old Wood Carving; mate to above.

267 Old Bronze Hibachi; square, with handles on two sides. Superb rich red bronze. 200 years old. Height, 9 inches.

268 Huge Tamba Bottle; warm gray glaze. Spray of peony and orchid painted in green and blue enamel. Unusually fine specimen. I 50 years old. Height, I 5 I -2 inches.

269 Pottery Tea Bowl; rich dark green glaze made by Raku Kichizayemon. Ioo years old.

270 Pottery Tea Bowl; Oribe Ware; green glaze over pinkish ground. Fine specimen. I 50 years old.

27 I Pottery Tea Bowl; Kioto Ware; decoration in several colors of enamel. Beautiful specimen. About I 800 . 



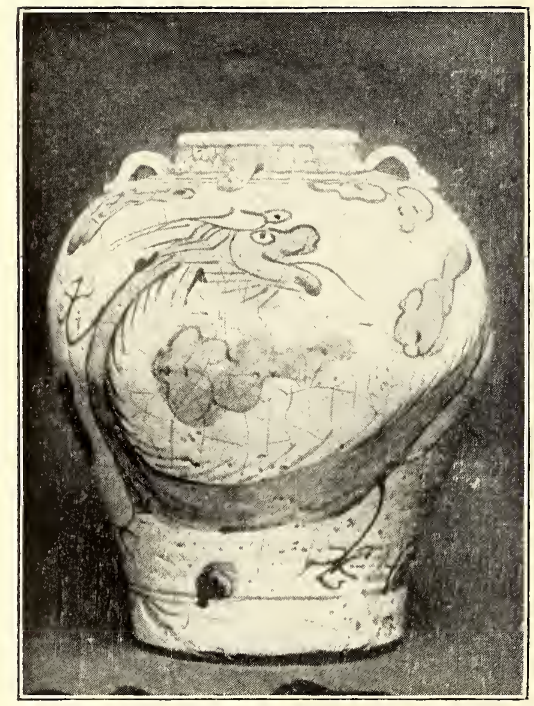

No. 276 . 
272 Old Kioto Bowl. God of Wealth painted under glaze. Inscription says: "The painting is copied from that of Tosa Mitsuoki, celebrated court painter.' Mate to one at Boston Museum of Fine Arts (Prof. Morse's collection). Made by Dozan.

273 Tea Bowl; Kioto Ware. Seven Wise Men, painted in various colored enamels. I 50 years old. Mark, Ninsei.

274 Porcelain Rice Cups (two pieces). Old blue and white Imari of fine rare quality. Over 200 years old.

275 Akahata Jar. Pale gray glaze. Has lacquer cover. Height, 6 inches. Date, I 830.

276 Old Blue and White Jar; superb glossy glaze of warm gray tint, fine soft crackle. Dragons and clouds painted in dull blue under the glaze. Made after the style of Anam Pottery. Maker or name cannot be identified. One of most important pieces in the collection. Height, I I inches. (See illustration.)

277 Old Shino Jar. Known as Shino Oribe; upper portion is light brown changing gradually to a warm gray. Exquisite "Kano School" landscape painted in India ink. It is a rare specimen of Shino and one of the most important pottery specimens in the collection. 250 years old. Height, 6 3-4 inches.

278 Old Kutani Jar with Cover. Dark brown glaze; storks and clouds painted in olive green. Oldest Kaga Ware in existence. Splendid specimen. Height, 8 I-2 inches. 


\section{RARE OLD PRINTS.}

279 Color Print by Harunobu. This most accomplished Master of Ukiyoe is a pupil of Shigenaga. His creations in printing prove him a genius of original stamp. Subject; Concert, the girl playing Koto and her lover the flute. Beautiful landscape screen at the back of the female figure; bamboo tree and flowers in court yard. Date, I 771 .

280 Color Print by Kiyonaga. Subject; Lady with Attendants and Jewelry Peddler. Superb coloring in the gowns. Kiyonaga is regarded by some as the central and culminating figure of Ukiyoe Masters. His inborn genius in coloring and composition is indeed wonderful. Date about I 780 .

28 I Color Print by Harunobu. Subject, Two Women Fulling Cloth with a Mallet. Exquisite blue wall beyond the bamboo window; Japanese native camelia in full bloom. Date, I770. Beautifully preserved.

282 Color Print by Kiyonaga; Group of Girls on Enclosed Porch. Delicate landscape beyond, a subject sel- . dom treated by Kiyonaga. Date about I 774 .

283 Color Print by Harunobu. Clear proof-print, Subject, Two Angels Descending on a Cloud Bearing Gifts to a Man. Date about i 760 . Wonderfully well preserved.

284 Color print by Hokusai. Subject, Women Diving in Search of Sea-Ear on Shore of Matsushima. Date about I 8 IO.

285 Color Print by Harunobu. Subject, Female Dancer. Date about I 755 .

286 Large Color Print by Hokusai; Waterfall of Kirifuri. Date, I 800.

287 Large Color Print by Korinsai; Girls Playing Cards. Very heavy, yet harmonious coloring. About I 778 . 
288 Color Print by Hokusai. View of Fugi Mountain from City of Yedo. Date about I 790.

289 Color Print by Utamaro. Subject, Lady with Two Attendants. The beautiful green and delicate pink in the garments are unusual in Utamaro's work. Date about i 8 Io.

290 Color Prints by Masayoshi. Subject, Two Warriors Swimming in Water. Very rare print. Date about I 740 .

29 I Large Color Prints by First Toyokuni, illustrating Japanese theatre, showing stage, seats and general arrangement; actors playing their parts. Some of the most interesting and valuable prints in existence. Date about I 789 .

292 Large Color Prints by Toyokuni, illustrating Japanese theatre. Date about i 800 .

293 Large Color Print by Kunisada. Fine illustration of Japanese "Green Room." Rare and interesting print, particularly because it bears exact date of time when it was printed. (January, Ioth year of Bunkwa, i 824, A. D.)

294 Large Color Print by Kunisada, illustrating green room of famous actor, Danjuro the Seventh. Valuable print. Date about is Io.

295 Large Color Print by Kunisada. Illustration of Banquet in green room of actor, Suketakaya, on the occasion of successful production of a play. Valuable print. Date about is 8 .

296 Large Color Print by Toyokuni. Illustrates a series of acts in play "Date Sodo." Valuable print. Date about I 8 IO.

297 Large Color Print by Toyokuni. Illustrates a series of acts in "Forty Seven Ronins." Very interesting print. Date about I 780 .

298 Old Flower Pot. Conventional pattern painted in blue under the glaze. Height, I 2 inches; diameter 8 inches. Date, I 800. 
299 Kutani Jar in form of plum. Scenes from Lake Biwa painted in various colored enamels in four panels. Has an elaborate decoration in green and soft yellow. Height, 8 I-4 inches.

300 Amakusuri Satsuma Vase. Rich brown glaze covers the entire vase. Dragon and conventional clouds carved in relief under the glaze. Very rare specimen. Height, I6 inches. Date, I 740.

30 I Ancient Colored Bronze, Iroye Doki Incense Burner. This precious object is one of the oldest and finest green bronzes of the Ioth Century. Long before the art of inlaid enamel work was discovered some of the most valuable bronzes were decorated on the outside with a peculiar coloring matter, now unknown, called "Iroe Doki" or "Colored Bronze." Magnificent subdued color is due to its great age. One of the treasures of the collection.

302 Old Bronze Vase; cylindrical, narrow at neck. Two Carp form the ears. The rim and scales of carp are inlaid in silver. Finest quality of olive bronze. Made about I 700. Height, 9 I-2 inches.

303 Old Bronze Jar; perfectly smooth quality of superb depth of color. Lion's head form the two ears. Height, 6 inches; diameter, 7 inches. Date about I 730 .

304 Ancient Arrow Heads and Coin (three pieces). Of all the arrow heads the collector has seen these are the most interesting. They are the oldest metal arrow heads used by the Japanese and are of a beautiful green color. Date about I600 A. D. The coin is called "Han Rio"; made during Chin period (400 A. D.).

305 Shozan Jar; decoration, grape vines painted in Kenzan blue. Fine soft crackles in glaze. Height, 8 I-2 inches; diameter, Io inches.

306 Kochin China Vase. Superb green glaze; strong conventional grass design carved in relief and glazed with yellow. Beautiful specimen. Height, I4 inches. Date about I 750 . 
307 Kioto Oblong Dish. Made by Bizan of Awata. Figure of "Noh Dance" painted in various colored enamels. Mark, Bizan. Date, i 850.

308 Karatsu Jar. Beautiful ecru glaze over conventional Mishima inlaid in light yellow. Very rare specimen. 200 years old. Height, 8 inches.

309 Banko Brush Stand. So old and fine a specimen is seldom seen. Two rural scenes on either side of the stand done in the most beautiful colors seen in Japanese pottery. One of the most important pieces in the collection. Date, I 730 . Height, 4 3-4 inches.

3 IO Awata Jar. Made in Kioto about I 700 A. D. Landscape painted under the glaze. Hard Satsumalike crackle with wonderful stain known as "Amamori Awata" or "Rain Stain Awata." Rare specimen. Height, 6 inches.

31 I Karatsu Bottle. Splash of bamboo, green over brown. Superb specimen, 300 years old. Important piece in the collection. Height, 8 inches.

3 I 2 Large Silk Embroidery; Wall Hanging. Sacred Dragon ascending in clouds. Entire space, 9 feet $\mathrm{x} 7$ feet, is covered with needlework, bordered with costly brocade.

3 I3 Golden Lotus Flowers with Bronze Vase. Used on alter in front of Buddha's Shrine in Temple of Nara. Gold lacquer over carved wood. The bronze vase was originally made to match. Rare object. Date, i68o.

3 I 4 Zeze Bottle. Tall, narrow at neck with nose. Three different glazes are put on one over the other. Rare specimen. Height, I 2 I-2 inches. Date, I 730.

3 I 5 Large Agano Bowl; in form of lotus leaf with frog on the edge. Beautiful bamboo green glaze. Height, 6 inches. Date, I 790.

3 I6 Seto Jar by Shuntai. Delicate olive green glaze, Mishima pattern carved under the glaze. Date, I 820 . Height, 6 inches. 
3 I 7 Soma Jar. Thin gray glaze over coarse clay. Two horses painted in India ink under the glaze. Height, 6 inches.

3 I 8 Shigaraki Jar. Green moss-like glaze covers white ground. Height, I 7 inches.

3 I9 Karatsu Bottle; warm gray with light brown stain. Height, 7 inches. 200 years old.

320 Old Color Print by Harunobu. Lady in Her Chamber. Date, I 750.

32 I Old Color Print by Buncho. Man and Woman Frolicing. Rare print. Date, I 770.

322 Large Color Print by Toyokuni. Lady and Gentleman Walking. Fine coloring. Date, I790.

323 Large Color Print by Utamaro. Two Ladies. Beautifully preserved. Date, I 790.

324 Large Color Print by Yeizan. Girl Holding Fan. One of the best Yeizan in the collection. Date, I 800.

325 Large Color Print by Yeizan. Girl Reading. Exquisite coloring. Date, I 800.

326 Colored Print, Landscape by Toyokuni. Temple of Tsurugaoka and Surrounding Scenery. Very rare print. Date, I 785.

327 Color Print by Korusai. Boy and Girl Playing with Bow and Arrow. Beautiful coloring. Date, I 770.

328 Large Color Print by Yeizan. Woman Reading Letter and infant looking in a glass. Pleasing colors. Date, i 800.

329 Large Color Print by Yeizan. Lady in Full Dress. Charming coloring. Date, I 800.

330 Large Silk Embroidery. Storks in Chrysanthemum Field. Exquisite work in needle painting executed by Nomura, famous tapestry maker in Kioto. 


\section{IMPOR'TAN'T TEA BOWLS.}

33 I Hagi Bowl. Soft ivory-like quality; beautiful crackle. Very rare specimen. Date, I 700.

332 Seto Bowl. Charming blue glaze. Made by Shuntai. Mark, Shuntai. Date, I 8 Io.

333 Raku Bowl. Dark gray with green shade of unusual depth. Manipulated clay. 250 years old.

334 Suyehirzan Bowl. Beautiful composition of various colored glaze makes the bowl peculiarly attractive. Date, I 850 .

335 Akahata Bowl. Large Tea Bowl; pine, plum and bamboo trees painted in green and brown enamels in a delicate manner. Mark, Bokuhaku Akahata. Date, about I 750 .

336 Yeiraku Bowl. Decoration, sun rising over the water. Attractive bowl. Mark, Ninsei. Date, I 800.

337 Banko Bowl. Delicate brown color. Emblem of treasures painted about the rim in various colored enamels. Made by Yusetsu. Date, I820.

338 Setosuke Bowl. Beautiful pale gray. Rare specimen. Mark, Setosuke.

339 Seto Bowl ; in form of plum blossom. Beautiful work by Shuntai. Date, I 800 . Signed.

340 Kioto Bowl. Beautiful gray and pink coloring with crests inlaid in white. Probably made by Dohachi. Date, I 820.

34 I Silk Embroidery Table Cover. Design, pair of Sacred Phœnix and peony blossoms. Elaborate work executed by Nomura.

342 Pottery Vase, Agano Ware. Delicate green glaze partly covered with rich brown. Height, I 2 I-2 inches. Date, I 700. 
343 Awata Jar. Crests of Imperial Chrysanthemum and conventional grass pattern painted in green and blue enamel in relief, touched up with gold. Made by first Hozan. Beautiful specimen. With teakwood stand. Date, I 730.

344 Seto Bowl; in form of boat. Rich black glaze with chrysanthemum crest. 200 years old.

345 Pottery Jar. Ofuke Ware, square, corrugated surface. Rich metalic brown glaze on black. Date, I750.

346 Large Color Print by Yacho. Subject, Scene on Summer Evening on Komo River, Kioto. Yacho was the pupil of the renowned artist Goshun about I 790, and was one of first artists to attempt to make prints in Kioto. His work is rare on account of his early death, and is highly admired by Japanese. (Very rare print.)

347 Old Color Print by Hokusai. Subject, Waterfall One of the most important Hokusai prints in the collection. Signed, Zen Hokusai. Date, I785.

348 Colored Print by Utamaro. Mother with Infant. Date, I 790 .

349 Color Print by Hokusai. Rapids of Isawa. Fugi Mountain in the distance. One of the strongest and best of Hokusai's works. Date, I 780.

350 Large Color Print by Utamaro. Lady's Head. Signed Utamaro. Date, I 790.

35 I Japanese Tansu-Wooden Cabinet. Made of white Kiri wood with iron handles and locks. Height, 37 inches; width, 35 I-2 inches; depth, I 5 inches. (See illustration.)

352 Tall Bronze Jar. Square sides, flaring at top. Height, I 8 inches. With teakwood stand. Has beautiful green and red mottled color.

353 Shozan Flower Jar. Spray of chrysanthemum painted in various colored enamels. Rim decorated with brocade pattern. Height, 9 inches; diameter, I I inches. 


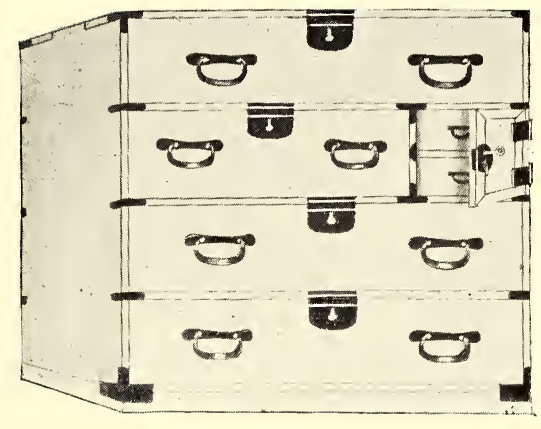

No. $35 \mathrm{I}$. 

354 Shozan Vase; blue and white conventional design. Height, I I inches.

355 Kioto Jar; gray glaze spotted with pink. Mishima border. Made Dohachi. I 820.

356 Porcelain Vase with stand to match; cloudy blue and gray glaze. Made by Gosuke of Seto, and received medal at Kioto Exposition in I 895 . Height, I 5 inches.

357 Awata Jar; creamy white glaze; native lily blossoms carved in relief under the glaze. Beautiful crackle. Height, I I inches; diameter, 8 I-2 inches. One of the most beautiful Kioto jars ever seen.

$35^{8}$ Four Fold Silk Screen; each panel 60 inches high and 20 inches wide. Valuable collection of ancient gold brocades mounted side by side, representing numerous old weavings.

359 Shozan Jar; Iris decoration in Kenzan blue. Beautiful crackle. Height, I 4 inches.

360 Porcelain Vase. The entire vase is decorated with many varieties of chrysanthemum in delicate colored enamels. Made by Shimidzu Nagoya. With teakwood stand.

36 I Porcelain Jar; decoration illustrating care of the silk cocoons.

362 Pottery Incense Jar; tiger skin glaze; grape vines carved in relief under the glaze. Made by Kinkozan. Height, 9 I-4 inches.

363 Porcelain Vase; rich amber brown glaze. Made by Gosuke, Seto Owari. Height, I 2 inches.

364 Hirado Dish (six pieces). Three gourds painted in different colored enamels. Diameter, 7 inches.

365 Small Iron Kettle; dragon in repousse. Fine old kettle. Date, I 700.

366 Bronze Kettle; in form of trunk of pine tree. Grain of the wood in repousse. Very fine quality of bronze Date, I700. 
367 Large Hanging Vase; in form of bottle. One side has ivy, wistaria and iris decoration in three fan shaped panels; other side Phœnix hovering over water. Elaborate brocade pattern about the body of bottle.

368 Enamel Vase; soft chocolate brown ground with chrysanthemum decoration in pink and white enamel. Made by Sudzuki, Nagoya. Height, Io inches.

369 Kioto Jar. Delicate Hawthorne pattern; plum blossoms in pink and white, ice crackle carved under the glaze. Soft creamy white. An attractive specimen. Height, I 2 inches.

370 Enamel Vase. Cherry blossoms in moonlight. Charming blue gray glaze. Made by Hattori, Nagoya. Height, Io inches.

37 I Enamel Vase. Decoration, cockerel and hen in chrysantheum garden. Height, IO inches.

372 Old Hirado Vase; dragon in relief rising from wine jar; blue and white decoration. Genuine old specimen. Date, I 800. Height, I I inches.

373 Arita Jar. Shape of morning glory. Conventional water and cloud decoration in blue and white. Made by Fujisaki of Arita, for Kioto Exposition in I 895. Received medal. Signed.

374 Arita Vase. Charming form. Conventional peony pattern in delicate blue and white. Height, I 2 inches.

375 Imari Jar. Decoration, Chinese landscape in blue and white.

\section{NOTE.}

Difference between Satsuma and Awata. These two wares are somewhat similar in their clay and glaze, and often they are greatly puzzling. The important feature in comparison is the difference in weight. Satsuma is heavier than Awata. Another ; Satsuma has hard and sharp crackle like marble, while Awata has soft, warm crackle like ivory.

The following are some of the most valuable Satsuma and Awata specimens in the collection. 
376 White Satsuma Bowl. Chosa-Faience. Made at Chosa in Providence of Osumi. Plain white; fine hard crackle; with metal rim. With teakwood stand. 220 years old.

377 Old Satsuma Bottle. In form of gourd. Fine hard marble-like crackle. Glorious specimen. Date, I 700 A. D. Height, io inches.

378 Satsuma Tea Bowl. Oldest Chosa specimen. Beautiful specimen. 300 years old.

379 Satsuma Tea Bowl; plain ivory white. Hard marblelike crackle. One of the most important tea bowls in the collection. Date, I 800 .

380 Satsuma Jar; cylindrical. Chosa-Faience; sharp crackle. Very fine quality of plain Satsuma. Date, I 700.

38 I Decorated Satsuma. Figure of Chin Dog Playing with Ball. Expression and attitude of dog is wonderfully natural. Rare specimen. Height, 6 inches. Date, i 820 .

382 Mishima Satsuma Teapot. Beautiful quality. Date, I 780 .

383 Decorated Satsuma Box. Square, with pine, bamboo, and plum tree in red, blue and green enamel and gold. Fine hard crackle. Rare specimen. Date, I 820 .

384 Satsuma Bowl; in form of flower. Floral decoration. Made by Chinjukan. Very fine specimen.

385 Tall Sake Bottle. Soft, ivory-like glaze with fine crackle. Figure of Shojo dancing along wine jar painted under the glaze. Date about i 780 . Height, I 6 inches.

386 Awata Bowl. Decoration, pine tree and bamboo painted in green and blue enamel. Crest of Tsuta in blue enamel. Beautiful crackle. Made by Kinkoan, I 790 .

387 Awata Sake Bottle. Conventional floral design painted in various colored enamels. Has beautiful stain. Height, 4 I-4 inches. Date, I 730. 
388 Awata Bowl. Plain cream white. Ivory-like quality, with fine crackle. Date, I 750.

389 Awata Bowl. Plain gray glaze; fine soft crackle. Beautiful specimen. Date, I 740.

390 Awata Covered Dish. This was originally bought by the collector for Satsuma, but mark found on the bottom faintly discernable under the glaze " Kinkozan." It is glorious old Kinkozan Awata. Date, I 770 .

39I Bronze Okimono; lotus plants in full blossom, heron wading among them. A Japanese native robin perched on the seed-pod which forms an incense burner; a crab crawling upon the rock. It is a graceful design in cast bronze. Made by Shimasa, Osaka. Height, 26 inches.

392 Bronze Dish; beautiful patina. Has delicate curved handles. Height, 3 inches. Date, I 700.

393 Small Bronze Vase; mottled red and green coloring like toad skin. 300 years old. Height, 4 I-2 inches.

394 Bronze dish; finest quality of ancient bronze. Used on altar to hold offering. 500 years old.

395 Bronze Vase; open work floral design in cast bronze. Height, 6 I-2 inches. Date, I 720.

396 Bronze Jar; exceedingly beautiful patina. Has delicate border near top. Pine cone ear with ring form handles. 200 years old.

397 Ofuke Jar; beautiful green glaze; dragon in relief under the glaze. Handles formed by lion's heads. Height, 8 I-2 inches; diameter, $\mathrm{IO}$ inches. About 200 years old.

398 Ofuke Vase; tall, hexagonal; beautiful green and white glaze. Very fine old specimen. 200 years old. Height, I 3 I-2 inches.

399 Hagi Covered Jar; low and flat; pinkish gray glaze. Made by Setsusan, Hagi. Height, 4 inches. 
400 Oribe Jar. Flat, hexagonal, beautiful green glaze. Fine hard crackle. Best specimen of Oribe in the collection. 200 years old. Height, 6 I-2 inches; diameter, 8 inches.

40 I Hagi Dish, in form of boat. Beautiful pink glaze. Height, 3 I-4 inches.

402 Temple Hanging Lamp in form of flower. Fine repousse work.

403 Japanese Tansu Wooden Cabinet, made of white Kiri wood with iron handles and locks. Height, 37 inches; width, 35 I-2 inches; depth, I 5 inches.

404 Embroidered Silk Table Cover; conventional Dragon and Sacred Phœenix embroidered in relief. Made by Nomura, celebrated tapestry maker of Kioto.

405 Silk Embroidered Square; design, royal chrysanthemum. Made by Nomura of Kioto, celebrated tapestry maker.

406 Embroidered Silk Square. Design, Dragon and Cloud. By Nomrua of Kioto.

407 Nabeshima Porcelain Bottle. Decoration, chrysanthemums and other flowers painted in blue under the glaze. Fine white clay. Rare old specimen. Date, I 750. With teakwood stand. Height, IO inches.

408 Chinese Ginger Jar; blue and white. Ching-lung Period (1736). Dragon and cloud painted in delicate powder blue under the glaze. Very important specimen. Height, IO I-2 inches. With teakwood stand.

409 Chinese Vase; Hsuan-Ti Period ( 1426 ). Beautiful blue and white conventional chrysanthemum design painted in blue under the glaze. Mark, Tai-ming Hsuan-Ti, Nen Sei. With teakwood stand.

4ro Chinese Tea Jar; deep blue glaze with delicate gold decoration. One of the most glorious porcelains produced in Kang-hsi Period. Delicate gold against the deep blue makes this a wonderfully attractive piece. With teakwood stand and teakwood cover with coral handle. Height, 12 I-2 inches. Kanghsi Period ( I662). 
4I I Chinese Vase; cylindrical; celebrated turquoise blue. Landscape carved under the glaze. Most important Chinese object in the collection. Height, 6 I-2 inches. With teakwood stand.

4I2 Large Kioto Bottle. Made by Kiudotei. Charming chrysanthemums painted under the glaze. One of the most attractive pieces of Kioto-Faience. Date, I 839. Inscription, Tenth year Tempo (9I,839). Made by Kindotei. Height, 20 inches.

4I3 Ofuke Hanging Vase; in form of boat; crab carved inside the vase to hold the stems of flowers. Beautiful glaze. Mark, Makusa. 200 years old.

4 4 Large Banquet Dish by Kasuke of Yamashiro. Round with scalloped edge. Spray of chrysanthemum painted in centre under the glaze. The rim is divided into panels decorated with various floral designs. Glorious green enamel used throughout the decoration. Kasuke was a contemporary of First Dohachi (about I740) and was one of the most distinguished potters in the Province of Yamashiro. This dish is without doubt, most wonderful Faience ever made by any Yamashiro potter. Mark, Rakukitei Kasuke, with seal. One of the most important Keramic objects in the collection. Date about I750. Diameter, 22 inches; height, 6 I-4 inches.

4I5 Large Kutani Dish; round and deep. Decoration, native peony painted in green purple and yellow enamel. Has an elaborate border. Very attractive specimen. Mark, Fuku. Date about I750. Diameter, I 8 I-2 inches.

4I6 Bronze Jar with Cover. Sinooth repousse in form of squash. Fine quality bronze. Height, 7 inches. Date about I 730 .

4I7 Green Bronze Vase; tall, slender form with lizard crawling about the neck. Beautiful work. Height, I 2 inches. With teakwood stand.

4I 8 Old Bronze Vase. Square, flaring at top. Date about 1650 . Height, 9 inches. 
4I9 Green Bronze Vase; long slender neck; charming green and cloudy red. Date, I 800 . Height, Io inches. With teakwood stand.

420 Shudo Bronze; low, flat body with slender neck. Conventional design in border about the vase. Superb scarlet spots all over the bronzes. Rare quality. Date about I775. With teakwood stand. Height, 7 inches.

42 I Green Bronze Bowl. For cut flowers; fine quality of old green bronze; exquisite patina. When struck gives a charming mellow tone which shows the genuine good quality of the bronze. Height, 3 I-2 inches.

\section{TEN IMPORTANT TEA BOWLS.}

422 Satsuma Tea Bowl, known as Seto Glaze Satsuma. Low, flat form; used in Summer Tea Party. Teagreen glaze over rich black. Date, 1670.

423 Kioto Tea Bowl. Awata Ware; charming decoration in relief of peony in green and dull red enamel. Soft ivory-like quality with crackle. Date, I 730.

424 Kutani Tea Bowl. Square with rich floral design in gold over dull coral red. Design inside in blue enamel. Rare specimen. Date, I750.

425 Kioto Tea Bowl. Made by Third Hohachi. Charming painting of Fugi Mountain and Willow in Spring. Date about I 820 .

426 Kioto Tea Bowl. Made by Second Rokubei; Seto glaze. Mark, "Sei," in double hexagon. Date, I 780.

427 Raku Tea Bowl. Made by Seventh Raku. Rich red with splash of dark green. Date about I720. Mark, "Raku" in double circle. 
428 Kioto Bowl by Third Dohachi. Exquisite faint painting of Fugi Yama in gray under the glaze. Date, I 820 .

429 Awata Bowl. Ivory-like glaze, fine crackle. Decoration, birds and tree in green and blue enamel. Date about I 700 .

430 Ohi Bowl. Rich brown glaze with simple decoration in yellow under the glaze. Beautiful irridescence. Date, I 8oo. Mark, Ohi.

43 I Awata Bowl. Spray of pine painted under the glaze by Keibun with his seal. Mark, Awata. Date, I 820. Beautiful specimen.

432 Large Shigaraki Jar. Streams of black glaze gradually changing to blue on each end. Magnificent composition of rich dark color. Used in keeping tea in wholesale tea houses. Made at Shigaraki about I650. Very important specimen. Height, 27 inches. With teakwood stand.

433 Kioto Vase. Delicate floral decoration on soft chocolate ground. Made by Tozan Ito. With teakwood stand. Height, 9 inches.

434 Iga Vase. Tall with corrugated surface covered with rich brown glaze. Splendid specimen of old Iga. Date about I650. Height, I 5 inches. With teakwood stand.

435 Giant Shigaraki Jar. Height, 5 feet, 3 inches. Beautiful bamboo green glaze; Japanese letters and crest of Tea House carved in relief under the glaze. This most extraordinary jar was made in Nakamura, a village in Shigaraki County, in Province of Omi, about I 720 A. D., for a sign for a wealthy Osaka tea merchant. It is positively the largest Keramic object ever produced in Japan. It is a hard pottery, strong as stone and stood in the merchant's tea garden nearly two centuries. It was brought to the port at Boston in a sailing vessel from Kobe, Japan, covering a distance of nearly 25,000 miles, and taking six months and eleven days. It has a cask to be packed in to go anywhere, which was the largest cask ever passed by the U. S. Custom House at Port of Boston. Has beautiful iron stands. 


\section{ORDERS EXECUTED WITHOUT CHARGE.}

Fifth Day's Sale-- Tuesday, April 26, at 3.

436 Six Solid Silver Spoons. Handles and bowls formed by Japanese flower carvings finished with gold. Made by Sanko, Famous Silversmith, Tokio.

437 Six Solid Silver Spoons. Beautiful floral design. Made by Sanko.

438 Six Orange Spoons. Handle of each has different floral design. Made by Sanko.

439 Six Tea Spoons. Beautiful chrysanthemum pattern. "Tokio Nippon" carved on each handle. Made by Sanko.

$44 \mathrm{O}^{2}$ Shozan Bottle. This is Shozan's favorite pattern, and he asserts that it is the hardest and most expensive design. A mass of peonies in silver, gold, purple, dull red aud Kenzan blue. With teakwood stand. Height, IO I-2 inches.

44I Old Hirado Celadon Vase. Cylindrical: landscape decoration in blue in four white panels. Delicate Celadon. Date about I680. Height, Io I-2 inches.

442 Tamba Sake Bottle. Upper part is covered with a pale blue glaze; the rest is black. Date, I750. Height, 7 inches.

443 Fine Old Kutani Dishes (in form of fish). Rich purple and green glaze. Mark, Fuku. Rare old specimen. Date, i 700.

444 Old Seto Dish. In form of leaf; made by Snuntai, about I 780 . Length, I 3 I-2 inches. 
445 Sake Bottle. Hexagonal in shape. Made at Isawa, Ise. Conventional floral pattern carved under pale green glaze. Mate to one at Boston Museum of Fine Arts (Professor Morse's collection). Mark, Isawa. Height, 8 I-2 inches.

446 Kioto Dish. In form of silk scarf with one corner turned up. Beautiful red and green glaze. Made by First Hozan of Kioto. Date about I 780.

447 Red Bronze Vase. In form of mallet; rich, glowing color. Made by Masaharu. Signed and sealed. Date, I780. With teakwood stand. Height, I 2 inches.

448 Arita Sake Bottle. In form of gourd. Design, various colored silk balls painted in enamel under the glaze. Date, I680. Height, 8 I-2 inches.

449 Figure of Owl perching on wooden stump. An attractive piece made in Kioto. Date about 1750. Height, Io inches.

450 Ivory Carving. Badger walking. Beautiful work.

$45 \mathrm{I}$ Ivory Carving. Badger walking.

452 Ivory Netsuke. Pommegranate. By Mitsuhiro.

453 Wooden Netsuke. Two monkeys.

454 Wooden Netsuke. Stone grinder.

455 Wooden Netsuke. Pup. By Minko.

456 Ivory Netsuke. Bat and tile.

457 Wooden Netsuke. Lion mask.

458 Wooden Netsuke. Rabbit.

459 Wooden Netsuke. Lotus seed-pod and seeds.

460 Wooden Netsuke. Tiger.

46 I Wooden Netsuke. Lotus seeds.

462 Ivory Netsuke. God of Wealth with bag of gold.

463 Ivory Netsuke. Old Hermit. 
464 Ivory Netsuke. Salmon.

465 Ivory Netsuke. Mikado's wheel.

466 Wooden Netsuke. Long Armed Man on back of Long Limbed Man catching fish.

467 Bronze Pigeon. Life size, skillfully wrought in bronze. Perfect in every detail. Made by Takachika, famous Bronze Maker of Tokio.

468 Japanese Chin Dog. Carved out in clay. Beautiful work of Hansuke.

469 Hagi Dish. In form of leaf. Light brown glaze.

470 Kishiu Jar. Rich purple and blue glaze. Mark, Kairaku Yen Sei.

47 I Awata Vase. Floral design painted in various colored ehamels under the glaze. Beautiful specimen.

472 Old Lacquer Trunk ornamented with bronze. Used in travelling by noblemen. Date about I 700 . Height, about $2 \mathrm{I}$ inches.

473 Old Hirado Dishes (five pieces). Scalloped edge. Floral decoration painted in blue under the glaze. I 50 years old.

474 Old Imari Dishes (five pieces). Hexagonal, deep blue decoration.

475 Old Imari Dishes (five pieces). Wise men in bamboo forest painted in blue under the glaze. 200 years old.

476 Old Imari Dishes (five pieces). Figure of Court Lady painted in various colored enamels. IOO years old.

477 Old Imari Plates (five pieces). Deep blue decoration. I 50 years old.

478 Ancient Imari Vase. Square, beautiful paintings in blue on four sides. Delicate border pattern. One of the choicest Imari pieces in the collection. Date about I600. Height, 9 I-2 inches. 
479 Idzumo Platter. Soft yellow glaze, beautiful crackle. Length, I 4 inches.

480 Imari Jar. Landscape painted in blue in two panels. Made by Yoichi Tashiro of Imari. Height, I I inches.

48 I Old Imari Plates (six pieces). Sacred Phœnix and peony in blue and red enamels touched with gold. 200 years old.

482 Imari Dishes (five pieces). Charming conventional Awoi leaves in blue. Fine quality. 200 years old.

483 Imari Dishes (five pieces). Children at play in blue enamel under the glaze. I 50 years old.

474 Owari Dishes (six pieces). Group of puppies painted in colored enamels in a delicate manner. Made by Shimidzu, Nagoya.

485 Large Imari Vase. Tall, flaring at top. Decoration, Sacred Dragon and Phœnix in colored enamels on brocade pattern ground. Conventional design painted in four panels near the base. Inner rim has delicate brocade pattern in coral red, which color predominates in the entire decoration. Brought from Buddhist Temple. Height, 25 inches. Made by Fukawa of Imari in the Province of Hizen. Date, I 800.

486 Imari Saucer (five pieces). Decoration in centre, hydrangea. Elaborate decoration on broad rim.

487 Two Puppies Frolicing. Carved from clay by Hansuke.

488 Agano Vase. Cylindrical. Beautiful bamboo green glaze on white. Height, I9 inches. Mark, Denko.

489 Seto Shunkozan Vase. Black glaze with splashes of rich amber. Made by Shunkozan, Seto. Date, I 500. Height, 8 3-4 inches.

490. Kiyonaga Prints. Lady and attendants on the way to Cherry Festival. Rare and original early print. About I 783 . 
49 I Yeizan. Two Girls carrying. Samisen Box. Date, about i 830 .

492 Kiyonaga Colored Print. Female Figure with Attendant. This is also one of the early works of Kiyonaga. Rich, yet difficult composition. A beautiful landscape on screen in the background. Date about i 770 .

493 Utamaro. Festival of Asakusa. Large Color Print. Date about i 780 .

494 Moronobu. Ink Print. Two Warriors Fighting on Bridge. It is fortunate this most interesting example was preserved to this day. It has a date on the margin: "May, 4th year of Genroku”, ( I69 I).

495 Toshinobu. Actor. Hand-colored Print, clear and well preserved. Use of a lacquered black is dropped and touched with pink and yellow. Fluff of beautiful detail in drapery. About I 735 .

496 Colored Print by Hiroshige. Subject, View of Lake Biwa. Date, I 820 .

497 Colored Print by Hiroshige. Landscape, “ Ishiyama.” Date, I 820 .

498 Colored Print by Hiroshige. Pines of Karasaki in the Rain. Date, I 820.

499 Colored Print by Hokusai. Ferry Boat. Date, I 790.

500 Colored Print by Shunko. Group of Ladies in front of silk store. Date, I 750 .

50 I Large Colored Print by Korusai. Lady drawing on screen with two attendants. Date, I 760.

502 Colored Print by Hokusai. Scene near Sumida River. Fugiyama in the distance. Date., i 8 Io.

503 Ivory Carving by Mingioku. Eagle with spread wings watching monkeys from top of pine. Attitude of monkeys is faithful to nature. Fine color. Height, 6 I -2 inches.

504 Ivory Netsuke. Woman with mushroom. 200 years old. 
505 Ivory Netsuke. Comical Dancing Figure.

506 Old Ivory Netsuke. Grandmother with baby.

507 Wooden Netsuke. Goat. By Tomotada. 200 years old.

508 Ivory Netsuke. Woman with mushroom. 200 years old.

509 Wooden Netsuke. Group of monkeys. I 50 years years old.

5 IO Wood and Ivory Carving. Man stealing wine by false mask. Important carving by Homin.

5 I I Ivory Netsuke. Baby with tub. By Sadatsugu. I 50 years old.

5I2 Wooden Netsuke. Rabbitt by Ranmei. IOO years old.

5 I 3 Ivory Netsuke. Man with fruit basket.

5 I 4 Ivory Netsuke. Chinese Warrior.

5 I 5 Old Kutani Jar with Cover. Decoration, floral design in two panels; elaborate brocade pattern about shoulder of jar in purple and yellow. Early green Kutani made about I650. Mark, Fuku. Height, I 8 inches. With teakwood stand.

5I6 Yellow Seto Vase. Tall, spindle shape; corrugated surface covered with thick yellow glaze. Date, I650. Height, IO I-2 inches.

5 I 7 Water Jug. Deep green glaze on corrugated surface. Made by Horaku, Nagoya. Hèight, 9 inches. Date, i 800 .

5 8 Old Seto Vase. A dash of black glaze on rich brown ground. With teakwood stand. Height, 7 inches.

5 I9 Shozan Jar. Decoration, plum blossoms in white in relief on finely crackled cream white ground. Height, I 2 inches. With teakwood stand.

520 Ancient Karatsu Bowl. Wave lines in white under dark gray glaze. 400 years old. 
52 I Hirado Bowls (eight pieces). Branch of maple partly carved in relief and painted with blue enamel under the glaze. Finest quality.

522 Banko Bowl. Flaring widely at top. Decoration in green, red and blue enamel. Mark, Banko. Date, I 750 .

523 Hirado Placque. Floral decoration in blue and red enamel. Cherry blossoms in fine coral red. Exceedingly fine color. Very rare in Hirado. Most important piece of Hirado in the collection. Diameter, 13 inches. Date, I 700.

524 Old Imari Dishes (seven pieces). Decoration, Lamb in pasture, painted in deep blue. Ioo years old.

525 Shozan Jar. Conventional plum blossoms painted in panels of Mirror black and green glaze. Height, I 2 inches.

526 Kinkozan Jar with Cover. Grape vine and fruit in relief. Toad forms handle to cover. Height, 5 inches.

527 Mulberry Wood Tray. View of Miyashima Temple and surrounding scenery carved in relief. Size, I 8 I-2 inches $\times 24$ inches.

528 Mulberry Wood Tray. Wild duck and poetry carved in relief. Grecian border about edge of tray.

529 Japanese Tansu. Wooden Cabinet. Made of native white Kiri wood with iron handles and locks. Height, 42 inches; width, 32 inches; depth, I6 inches.

530 Lamp. Stand is made of fine Seto Jar. Shade decorated with lotus flowers and leaves. Height, 34 inches.

53 I Pair of Repousse Brass Placques. Used in Buddhist Temple to serve lotus petals upon.

532 Embroidered Silk Hanging. Cockerel and mother hen with chicks among bamboo and chrysanthemum. Every detail faithfully carried out. Size 7 feet, x 4 feet, 7 inches. Border of gold Donsu Silk. Made by Nomura, Kioto. 
533 Silk Embroidered Screen. Group of Japanese native stork embroidered in relief on black satin ground. Beautiful silk brocade border. Height, 5 feet (four panels). Made by Takashimaya.

534 Embroidered Silk Screen (four panels). Design, flowers and birds on old gold satin. Silk brocade border. Height, 5 feet. Made by Takashimaya.

535 Silk Embroidered Screen. Tiger Lily blossoms beautifully embroidered on dark red satin. Silk brocade border. Four panels. One of the most beautiful works of Takashimaya. Height, 5 feet, 9 inches.

\section{ORDERS EXECUTED WITHOUT CHARGE.}

\section{Sixth Day's Sale - Wednesday, April 27, at 3.}

6or Solid Camphor Wood Chest; made of wood from camphor tree brought from Formosa. With Shakudo metal handles. Length, 20 inches; width, 9 inches; depth, 8 inches.

\section{CABINET OBJEC'TS.}

602 Tea Jar; blue glaze over brownish black. Mark, Sakuraino Seto. Date, I 750.

603 Owari Vase: decoration, many varieties of chrysanthemum in delicate colored enamels. Made by Shimidzu.

604 Old Satsuma Jar; fine crackle. Date, I680.

605 Purple Satsuma; decorated with gold dragon in relief.

606 Miniature Satsuma by Kozan; decoration done with the use of a magnifying glass.

607 Miniature Bronze Kettle.

608 Old Satsuma Netsuke: fine specimen. ioo years old. 



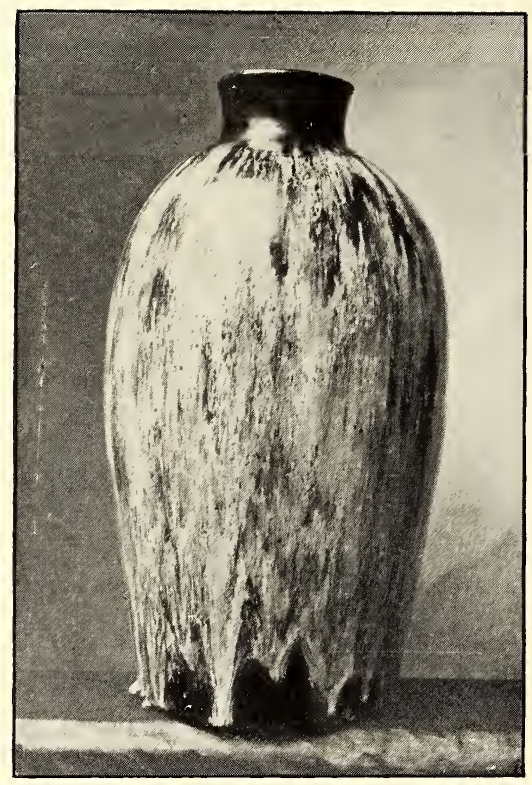

No. 618 



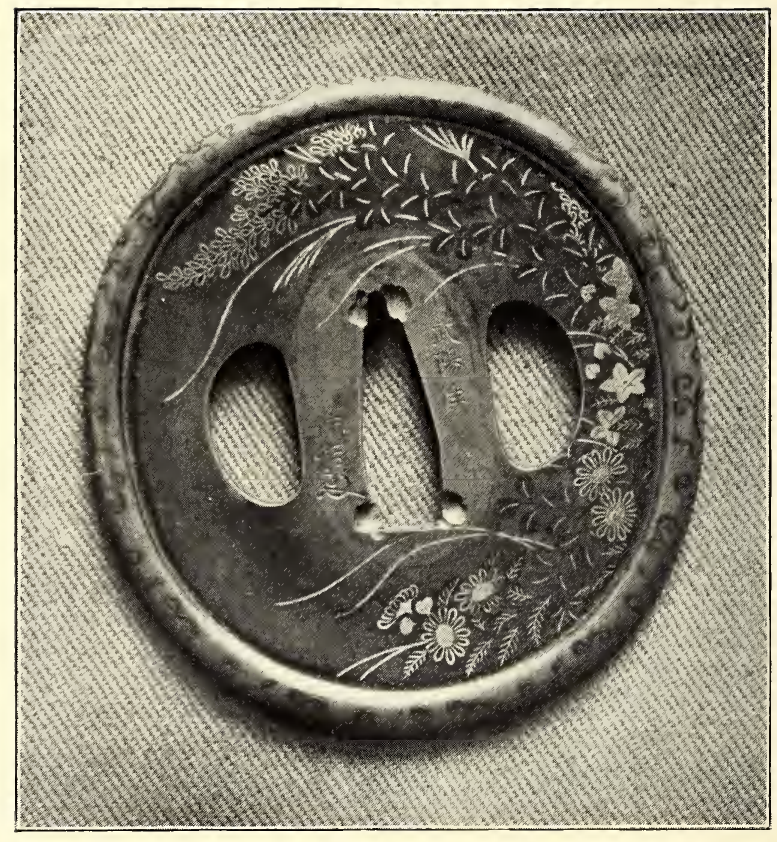

No. 620. 
609 Incense Jar; made from shell with lacquered cover.

6 Iо Goat carved out of clay, by Hansuke.

6I I Nagoya Vase; decoration, cockerel and hen painted in enamel.

612 Satsuma Bowl in form of flower with decoration in gold.

6r3 Hozan Jar; date, i780. Beautiful specimen.

6 It Awata Vase; Fugi Mountain and cherry blossoms.

6r5 Pair of Solid Silver Spoons; bowl and handle formed by blossom and stem of flower. Signature of "Long Life" on handle.

6I6 Coffee Spoons (six pieces); bowl of spoon in form of chrysanthemum blossom; beautifully wrought handle. "Tokio Japan" carved on each handle.

6r7 Orange Spoons (six pieces); stem and blossom of different Japanese flowers form handles.

618 Iarge Seto Kusuri Satsuma Vase; marvelious bine Seto glaze covers the entire vase. This wonderful Satsuma was in the possession of Mr. Imaidzumi, chief instructor in Kioto Art School. It is without doubt, one of the most perfectly glazed Satsumas ever made. Date about I7oo. Height, 26 inches. With teakwood stand. (See illustration.)

6I9 Mirror Black Satsuma; beautiful form; rich black glaze. One of the most important pieces in the collection. Height, I I I-2 inches, with teakwood stand.

620 Sword Guard; beautiful yellow gold bronze inlaid with Shakudo and gold; design on one side, autumnal flowers: on other side View of Lake Biwa in beautiful inlaid work. Made by celebrated Sword Guard Maker, Nakawoki, in Province of Musashi.

Date, i70o. (See illustration.)

62 I Sword Guard; yellow gold bronze with floral decoration inlaid in Shakudo and gold. By famous Meiju Umetada. Date about 1650. Signed.

622 Sword Guard by Kitakawa; Beautiful Shakudo metal. About 200 years old.

623 Sword Guard; Dragon inlaid in gold. 300 years old.

624 Sword Guard; in form of rabbit. Made by Katsuhisa.

625 Sword Guard; in form of monkey holding persimmon. By Katsuhisa. 
626 Shakudo Sword Guard; travelling priest and moon. By Natsuwo, celebrated metal carver in the Imperial Household.

627 Iron Sword Guard; perforated design. Dragon.

628 Iron Sword Guard; perforated design. Tea Utensils. 300 years old.

629 Iron Sword Guard; perforated design. Maple lcaves. By Masatsume. 250 years old. Signed.

\section{NOTE.}

Mitsuhrio Bronze. Mitsuhiro, the foremost living caster of Japanese bronze is about sixty-five years of age. His insignificant little dwelling is in Kanda, Tokio. $\mathrm{He}$ is peculiarly eccentric in his habits, sleeping always in his own workroom. But he is at once noble and original in his design and color, and ranks deservedly with old and great masters such as Seimin and Toun.

6,30 Mitsuhiro Bronze Vase; Japanese mountain trout in water; beautiful quality of green bronze. Height, I4 inches.

63I Mitsuhiro Bronze Vase; Chidori bird and waves in relief. Fine bronze; beautiful patina. Height, I4 inches.

632 Mitsuhiro Bronze; beautiful form, smooth surface with fine green coloring.

633 Mitsuhiro Bronze Vase; fine quality of green bronze.

634 Mitsuhiro Bronze Vase; flying birds in relief.

635 Three Important White Satsuma.

$6_{35}$ Muji Satsuma Vase; plain cream color; fine hard crackle. Height, 8 inches. Date about I7oo. With teakwood stand. (See illustration.)

636 Muji Satsuma Vase; plain cream glaze; finest marblelike crackle. Has finely carved imps' heads in relief under the glaze. Superb specimen in the collection. Height. 12 inches. Date, I700. With teakwood stand.

637 Muji Satsuma Vase; hard, marble-like crackle. IJas a band of emblems carved under the glaze. Charming specimen. Date, I7oo. (See illustration.) With teakwood stand. 


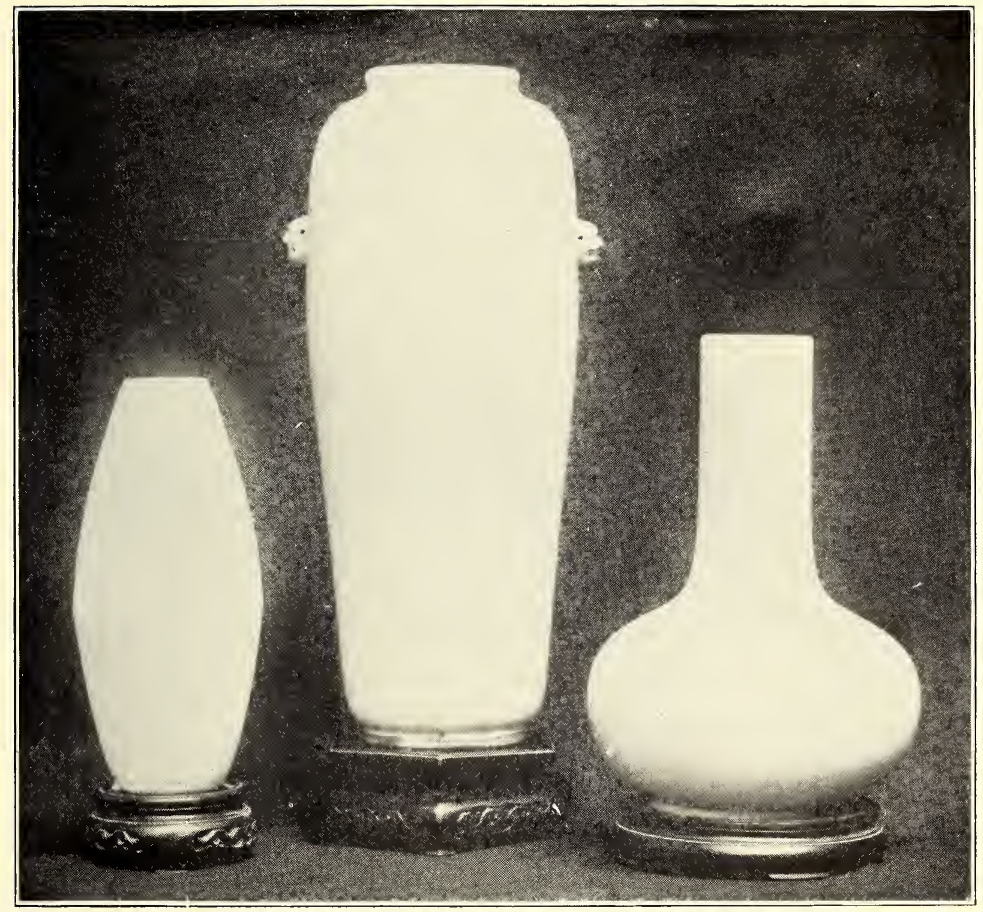

No. 637 .

No. $6_{3} 6$.

No. $6_{35}$. 




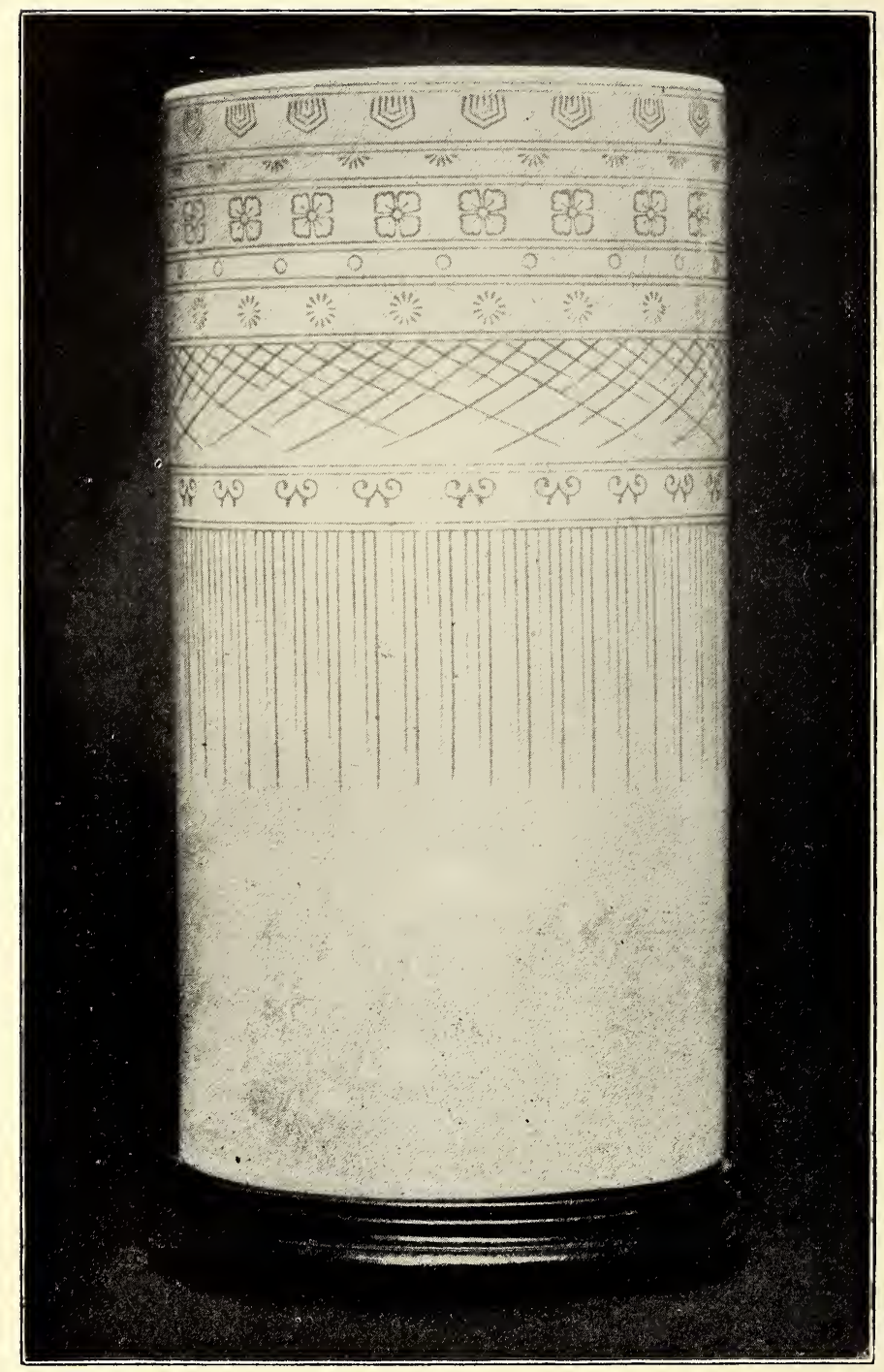

No. 652 . 
638 Brass Temple Hanging Lantern; beautiful repousse finish.

639 Old Imari Dishes (five pieces); pine trees painted under the glaze; has beautiful Karakusa border. 200 years old.

640 Hirado Dishes (five pieces); beautiful blue decoration.

64I Old Imari Dishes (five pieces); decoration, gold fish in green and purple enamel. Has deep blue border. 300 years old. Finest Imari Dishes.

642 Old Imari Dishes (five pieces); landscape in green and brown enamel.

643 Hirado Oblong Dishes (five pieces); dragon painted in blue in the centre with elaborate Karakusa design border. Finest in collection. 200 years old.

644 Hirado Saucer (five pieces); beautiful blue decoration.

645 Kioto Tea Bowl; made by Second Dohachi; I79o.

646 Takatori Tea Bowl.

647 Raku Tea Bowl.

648 Green Raku Tea Bowl.

649 Awata Tea Bowl; spray of cherry blossoms and moon painted under glaze. Very fine crackle.

$6_{50}$ Kioto Bowl; in form of basket. Ioo years old.

65 I Kioto Tea Bowl; beautiful pink and cream glaze. Made by Second Rokubei.

652 Mishima Satsuma Vase; cylindrical; Japanese calendar design carved very minutely under the glaze. Has hard, marble-like crackle. It is a perfect specimen of Mishima Satsuma made in Nayeshirogawa in the Province of Satsuma. Considered the gem of the collection. Height, I2 inches. With teakwood stand. (See illustration.)

653 Maizan Satsuma Bowl; minute butterfly, chrysanthemum and brocade border decoration; decoration in centre represents a bride with attendants about to enter gate. So delicate a color effect is seldom produced in Maizan, Satsuma. All work done under the magnifying glass. 
654 Satsuma Bowl by Kozan; in form of plum blossom. Exquisite decoration.

655 Satsuma Jar by Kozan; exquisite work illustrating Japanese Ladies' Party. With teakwood stand.

656 Satsuma Tea Bowl; spray of chrysanthemum painted in various colored enamels. Signed, Gioku Maizan's Satsuma. Very fine specimen.

657 Satsuma Cup and Saucer; beautiful, minute decoration by Kozan.

658 Ivory Netsuke inlaid with mother-of-pearl and coral; New Year's 'Tree.

659 Wooden Netsuke; man trying to lift a stone.

660 Mooden Netsuke; owl and bat on art tile. By Karaku. Signed.

66I Ivory Netsuke; butterfly lighted on a bean.

662 Ivory Netsuke; cow with God of Wealth on its head.

65.3 Ivory Netsuke; group of monkeys with turnip. Very fine carving.

664 Ivory Netsuke; mask of Okame.

665 Wooden Netsuke; mask of Okame.

656 Ivory Netsuke; wolf.

667 Ivrory Netsuke; mask of Okina.

668 Wooden Netsuke; mask of Monkey.

669 Coral red Chinese Vase; Kang-hsi Period, I662. Giorions red enamel. The faint horizontal line in the centre indicates that the vase was originally fashioned upon the wheel in two pieces. Has carved teakwood stand. Height, 8 inches.

670 Seimin Bronze; group of turtles crawling over rock. Life" on handle.

It is a wonderful piece of work seldom accomplished by Seimin. Attitude of each turtle is different; that of the one on the summit of rock apparently is attracting the attention of the others who are crawling toward it. The whole is a piece of exquisite workmanship. Date about I73o. 
67I Hanging Brass Temple Lantern; body of lantern has open work conventional chrysanthemum design with flaring, leaf-like ornaments at base and top. Pleasing form.

672 Seto Jar; black marking on rich brown glaze. Height, 6 inches.

673 Iga Jar with cover; mottled brown glaze on rough sur. face. Height, 6 inches.

674 Chinese Vase, Kang-hsi period, i662. Entire body of vase is covered with a rich coral red enamel. Beautiful form, with teakwood stand. Height, Io inches.

675 Sleeping Cat-porcelain-wonderful reproduction of famous carving in Nikko by Hidari Jingors (Japanese Farmingo); maker unknown. Length, 8 inches.

676 Large Imari Punch Bowl; inside is decorated with panels of beautiful floral and brocade designs in red and blue enamels touched with gold. Centre of bowl has conventional Howo Bird with Imperial Kiri crest. Outside decoration represents a growth of bamboo painted in blue and gold with conventional horder about the rim and base of bowl. Height, 8 inches; diameter, I7 inches.

677 Tiger-skin Satsuma Vase; spherical; beantiful transparent glaze over yellow and black motted surface. Height, 8 inches.

678 Kioto Vase, tall, hexagonal tapering toward the top. A dragon painted in relief in red and white enamel encircles the vase. Rich blue and gold objects representing precious gems are placed at irregular intervals all over the vase. Height, I 2 inches.

679 Green Banko Dish, in form of arrowhead leaf, decorated with blossom of the plant in yellow. I50 years old. Mark, Banko.

680 Bowl by Second Rokubei. Decorated on the inside with leaves of various plants in red, yellow and green enamel on light ecru ground. Diameter, 7 I-2 inches.

68 i Old Imari Plates (five pieces); centre of plate has decoration representing a man on the back of a fish, surrounded by a conventional border in rich, dark blue. I 50 years old. 
682 Old Imari Dishes (five pieces); decoration, landscape in blue under the glaze. I 50 years old.

683 Old Kutani Figure made by Goto Saijiro. Kutani or Kaga ware was first established in the village of $\mathrm{Ku}$ tani in the province of Kaga about I630, under the instruction of Prince Mayeda. Goto Saijiro was sent by the prince to Arita to study the method of making porcelain there. After his return from Arita, about 1655, he made himself very famous. It is said that he learned porcelain making and enamel painting from Kakiyemon. Specimens of his work are hard to obtain. The red enamel is of a very fine, dull, coral red. The texture of the porcelain forming the face of the figure is superior to any porcelain ever produced in Japan. Height, I2 inches. A gem of the collection. (See illustration.)

684 Old Awata Figure, representing "Noh" Dancer with mask; figure is clad in a red brocade gown. Dignified attitude is characteristic of the dance. I 50 years old.

685 Japanese Cabinet; made of burnt cedar and native white wood. Height, 28 inches; width, 24 inches.

686 Black Rakı Bowl; rich glowing red over black. Superb coloring, very rare. Made by Raku the Seventh. Date about I 700 .

687 Black Raku Bowl; fine iridescence. Made by Kensan. Signed. Date about i69o.

688 Red Raku Bowl.

680. Black Raku Bowl splashed with dull green.

690 Blue and White Kioto Dish; hexagonal, with three fect. Delicate landscape painted under the glaze. Date about I700.

Ggr Seto Kusuri Satsuma Bottle; in form of gourd. Fine, deep purple glaze. Date, I8oo. Height, 7 I-2 inches.

692. Hirado Punch Bowl; carp swimming near water plants painted in blue. Mass of cherry blossoms from a border about the rim. Diameter, I 5 inches; height, 9 inches. 


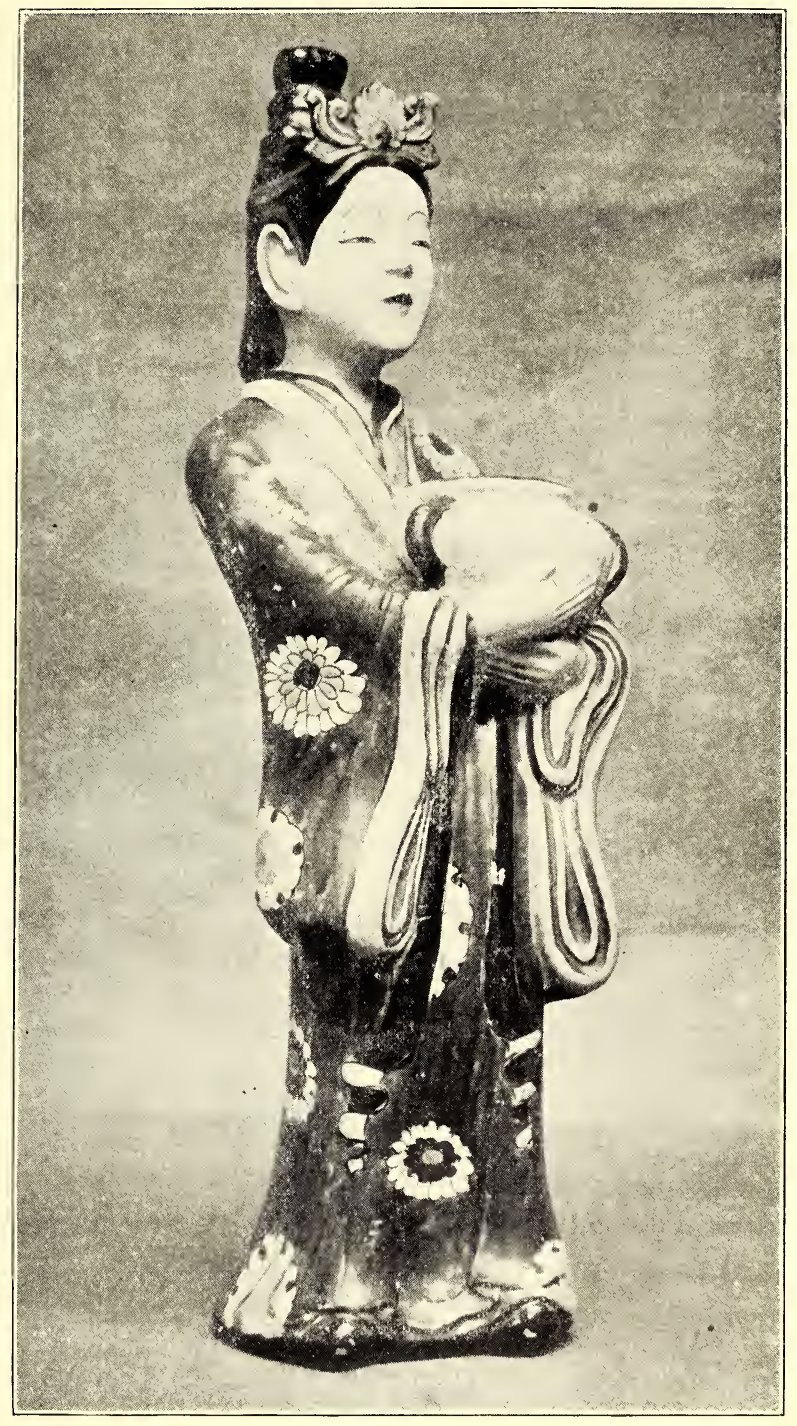

No. 683 . 

603 Shigaraki Jar; green and white glaze on corrugated surface. Height, 18 inches.

694 Five pieces Old Takatori Dishes; brown mottlerl glaze. Mark, Tata. Date, I820.

695 Old Takatori Dishes (five pieces); Hakeme glaze in gray. Very old specimens. Date, izoo.

696 Bronze Teapot: beautifully hammered out and jointed in the midclle. Has a unique hancile. Very sine quality, made by Nagori, celebratrel bronze maker. Date about 1720 .

697 Sake Warming Kettle. A soild silver pipe is coiled abont inside the kettle through winch the sake lesses and is kept at the rigint temperature by the hot water in the kettle. The tunnel is in form of a morning glory blossom, solid silver. Very interesting object.

698 Bronze Incense Burner; fine yuality oi old green bronze. Spherical shape. 500 years old.

699 Forcelain Vase; elliptical, with beautiful decoration of iris and. foliage in white and green enamel on dark blue groind. Height, 19 inches.

700 Porcelain Vase: decoration, white iris on deep red ground. Height, 19 inches.

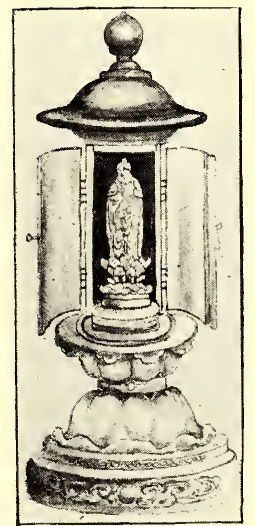

No. $\subseteq 2$. 


\section{ORDERS EXECUTED WITHOUT CHARGE.}

\section{Seventh Day's Sale - Thursday, April 28, at 3.}

7O I Hanging Temple Lantern; beautiful repousse.

702 Ancient Karatsu Jar; green glaze over corrugated body. Hard reddish clay. Fine, rare specimen. Date about 1500 .

703 Seto Vase; made by Gosuke. Cylindrical, tapering toward the top; rich black glaze over glowing red. Received silver medal at Kioto Exposition in I895. One of the most important Keramic objects in the collection. With teakwood stand. Height, Io inches.

704 Kinkozan Vase; made by Sobei Kinkozan. Exquisite form position in I895. Very important piece. Hejght, $6 \mathrm{I}-2$ inches. With teakwood stand.

705 Old Green Bronze Lantern; with iron chain; hexagonal, the doors are perforated net pattern. One of two best bronze lanterns in the collection. Date about I730.

NOTE.

Watanabe Seitei is about fifty-three years old, and lives in Asakusa, Tokio. He first studied painting under the late Kikuchi Yosai, a celebrated modern painter of Osaka. Later he produced his own style of such originality and coloring that he at once made himself famous the world over.

Famous enamel work of Namikawa and Suzuki and celebrated silk brocades of Nishimura and Takashimaya owe their reputation to Seitei's design. Now he paints very seldom and already Tokio market is full of imitations of his work. The collector being well acquainted with Seitei will vouch that these are the best works of Seitei during the last two years. Specially painted for the collection. 


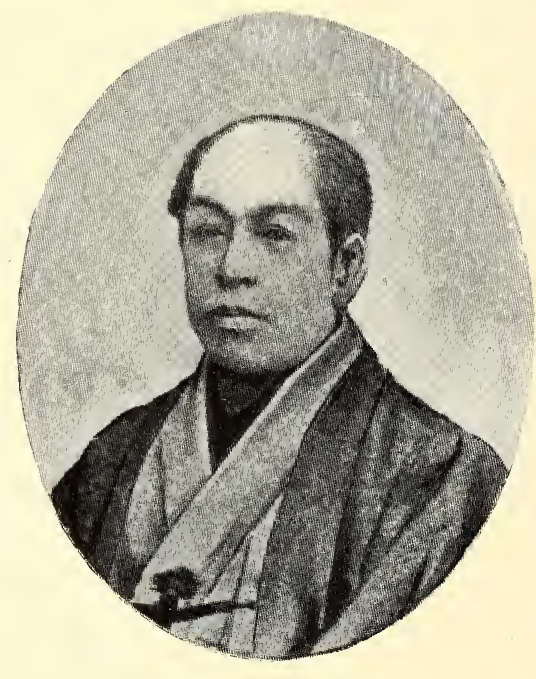

WATANABE SEITEI. 




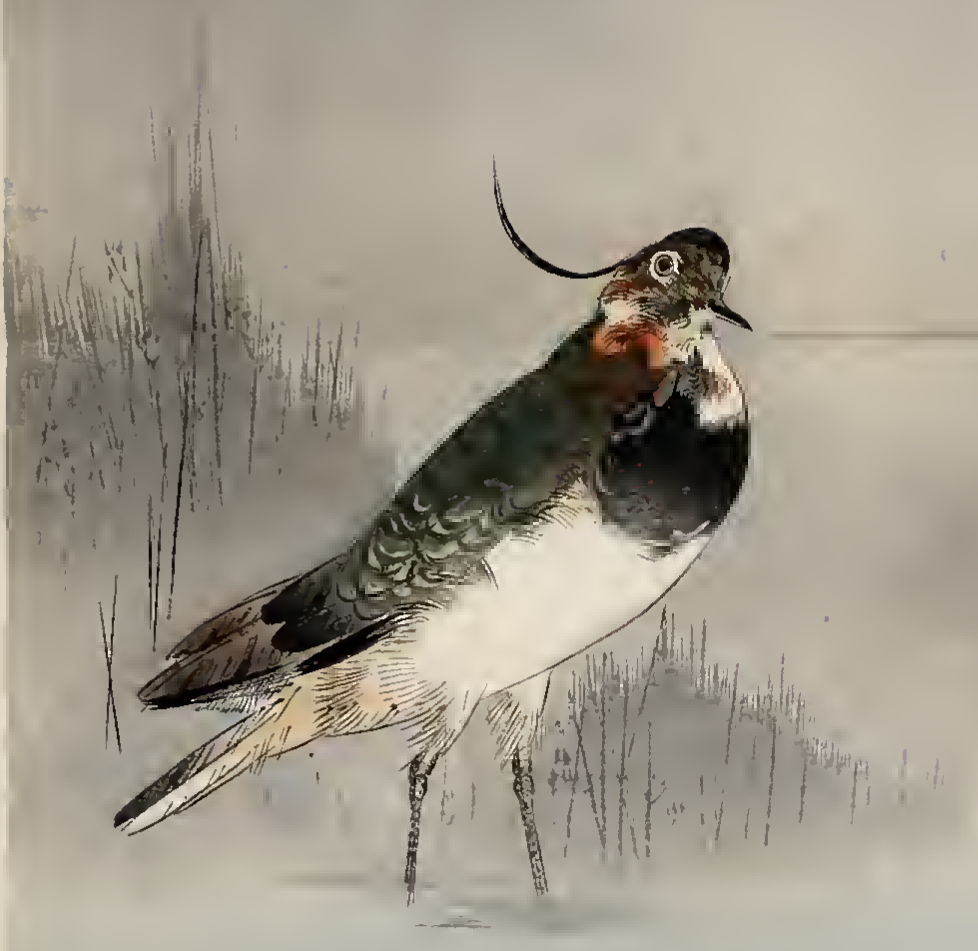

723 

706 Painting on silk by Seitei; Doves in Temple Yard. Shows a flock of doves hovering about a bionle fountain in a temple yard. This same subject was painted by the artist for the Paris Exposition, I889, and though many requested him to reproduce it, he was unwilling to do so; but at the earnest request of the collector this charming work was accomplished with the promise that it would be for the last time.

zo7 Painting on Torinoko paper by Seitei; blackbird in wheat field.

708 Painting on Torinoko paper by Seitei; carp and watergrass.

709 Painting on silk by Seitei; duck and drake.

7 Io Painting on Torinoko paper by Seitei; "White lily and snail."

7I I Painting on silk by Seitei; "A shower."

7I2 Painting on silk by Seitei; peony under snow.

7I3 Painting on Torinoko paper by Seitei; red carp in pool.

7I4 Painting on silk by Seitei; "Bank of Sumida River on Spring Evening." Charming cherry blossoms and willow.

7I5 Painting on Torinoko paper by Seitei; Japanese native blackbird in field of ripening rice. Great favorite of the collector's.

715 Painting on Torinoko paper by Seitei; Japanese songbird on willow.

7:7 Painting on Torinoko paper by Seitei; Onaga (longtailed) gold fish in lily pond.

7 I8 Painting on silk by Seitei; trio of Japanese birds.

7I9 Painting on silk by Seitei; a moonlght night in spring. Received first medal in Tokio Water Color Exhibition, 1897 .

720 Painting on Torinoko paper by Seitei; birds in: autum?n.

$72 \mathrm{I}$ Painting on silk by Seitei; plum tree and nightingale.

722 Painting on Torinoko paper by Seitei; grasshopper and grasses. 
723 Painting on Torinoko paper by Seitei; Japanese marsh bird. (Seitei's great favorite.)

724 Painting on silk by Seitei; autumnal vines.

725 Painting on Torinoko paper by Seitei; Japanese native bird-Mozu-perched on a willow after a shower.

726 Painting on silk by Seitei; moonlight snow scene. Croivs hovering about the trees, waterfall in the distance. A remarkable creation by Seitei in India ink.

727 Painting on silk; two pigeons perched on maple tree. Charming, soft coloring.

728 Painting on silk; two heron wading under a weeping willow.

729 Painting on silk; two pigeon and "icho" leaves.

730 Porcelain Bowl, Koto Ware, in Province of Omi. This ware was made at a private factory of Prince $\mathrm{Ii}$ of Hikone. Since the factory was situated on the eastern shore of Lake Biwa, it was called Koto (east of the lake). It is very interesting to compare this ware with Arita and Kaga, as the coral red enamel used in this ware is even finer than "Hachiroye Kinrande." This ware is highly estimated for its artistic qualities. Unusual specimen. Mark, Koto; date, I8oo.

$73 \mathrm{I}$ Karatsu Tea Bowl: white splash of "Hakeme" or brush mark on pinkish brown glaze. Date, I650.

732 Shozan Vase; cylindrical, decorated with spray of chrysanthemum in various enamels. Fine crackle. Height, Io inches.

733 Enamel Panel; a bewitching view of Sacred Fugiyama in spring as seen from Gotemba Station. Size, $2 \mathrm{I}$ in. $\mathbf{x}$ I4 in. This wonderful enamel work is known as "Museu Hippo," or enamel without line. The clouds have all the appearance of motion.

Fugiyama - the " matchless mount,"

"Everything is thine from base to summit up,

The little jungle-flowers, the tall and windy pine,

And the passing pilgrim's prayer, all and all are thine:

The weary-of-wing vulture eagerly crowns the crest,

And, proud as a Mikado there, he drops into his nest:

Yes, all and all is thine, from base to summit up."

Made by Sudzuki, Nagoya. (See frontispiece.) 



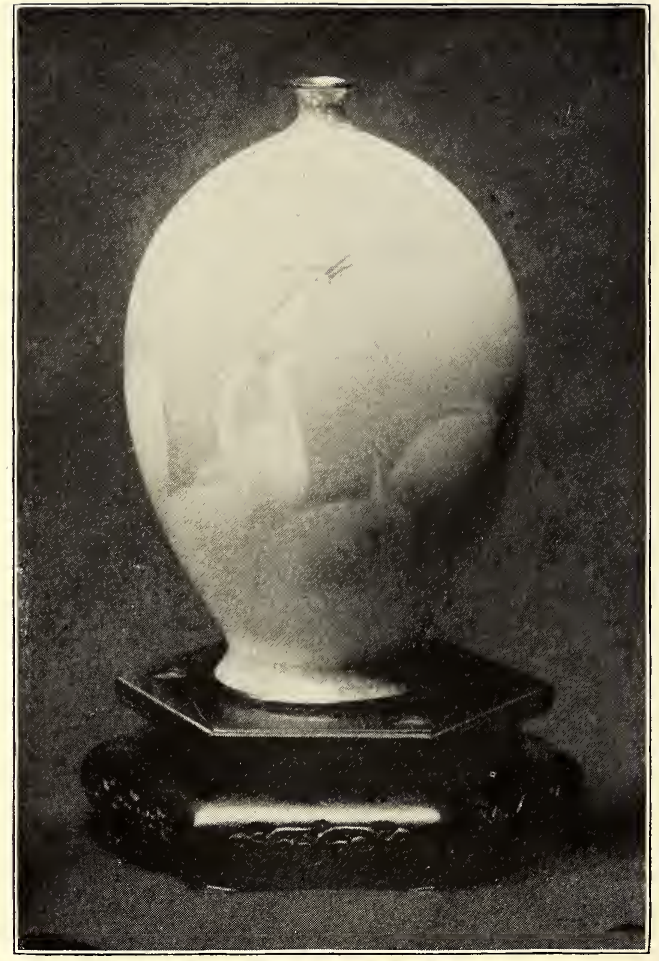

No. 734 . 
734 Vase; enamel on silver. Group of heron awakening at rosy dawn. This is another "enamel without line" save in the bird's bill and the delicate water design in the border at the base of the vase. In form, color and design this vase surpasses any enamel work brought over to this country. Made by Namikawa Sosuke. Height, 6 I-4 inches. With teakwood stand. (See illustration.)

735 Enamel Vase; group of storks on delicate green ground. Charming bit of enamel. Made by Namikawa Sosuke. Height, 3 I-2 inches. With teakwood stand.

\section{KAKEMONO BY GREAT ARTISTS.}

736 Painting on silk by Okio; carp swimning. Genuineness guaranteed. Date about I790.

737 Painting on silk by Keibun; parlor fire-works and Japanese fan. Date about 1830.

738 Painting on silk by Okio; badgers and moon. Date abont 1780.

739 Painting on silk by Gioktho; snow scene near Biwa Lake. Date about I8oo.

740 Painting on silk by Giokuho; Takawo in autumn. Mate to one above.

74I Painting on Toshi paper by Kadzunori; eagle.

742 Painting on silk by Motonobu; falcon. Date about I6oo.

743 Painting on silk by Kokei-a pupil of Okio-hermit on carp. Date I8oo. 


\section{OLD GOLD LACQUERS.}

744 Gold Lacquer Box; Imperial crests inlaid in gold and Mother of Pearl with Chinkin powder all over the ground. Made in Kwanei. Era I624-I634. Glorious specimen.

745 Gold Lacquer Box; various crests in gold on "Nashiji" ground. Fine quality. Date about I7oo.

7460 Old Gold Lacquer Incense Box; figure of Shojo holding Sake jar. Date about I7oo.

747 Old Gold Lacquer Box; square with dignified floral design. Date, I650.

748 Old Gold Lacquer Box; Imperial crests of Kiri on "Nashiji" lacquer ground. Fine quality. Made in Toyotomi's time. I590.

749 Old Gold Lacquer Tea Jar; spray of chrysanthemum in gold on black lacquer. Made by Kajikawa about I700. Signed and sealed.

750 Set of Sake Cups (three pieces); Kakemono in gold on red lacquer. Date about I750.

75I Tsuishu Lacquer Compartment Box; deep and wonderful carving. Finest quality. Has beatuful bamboo basket. Made by Yosei. Date, $165^{8}$.

752 Tsuishu Lacquer Tray; fine carving. Made by Yosei. Date, 1658. 



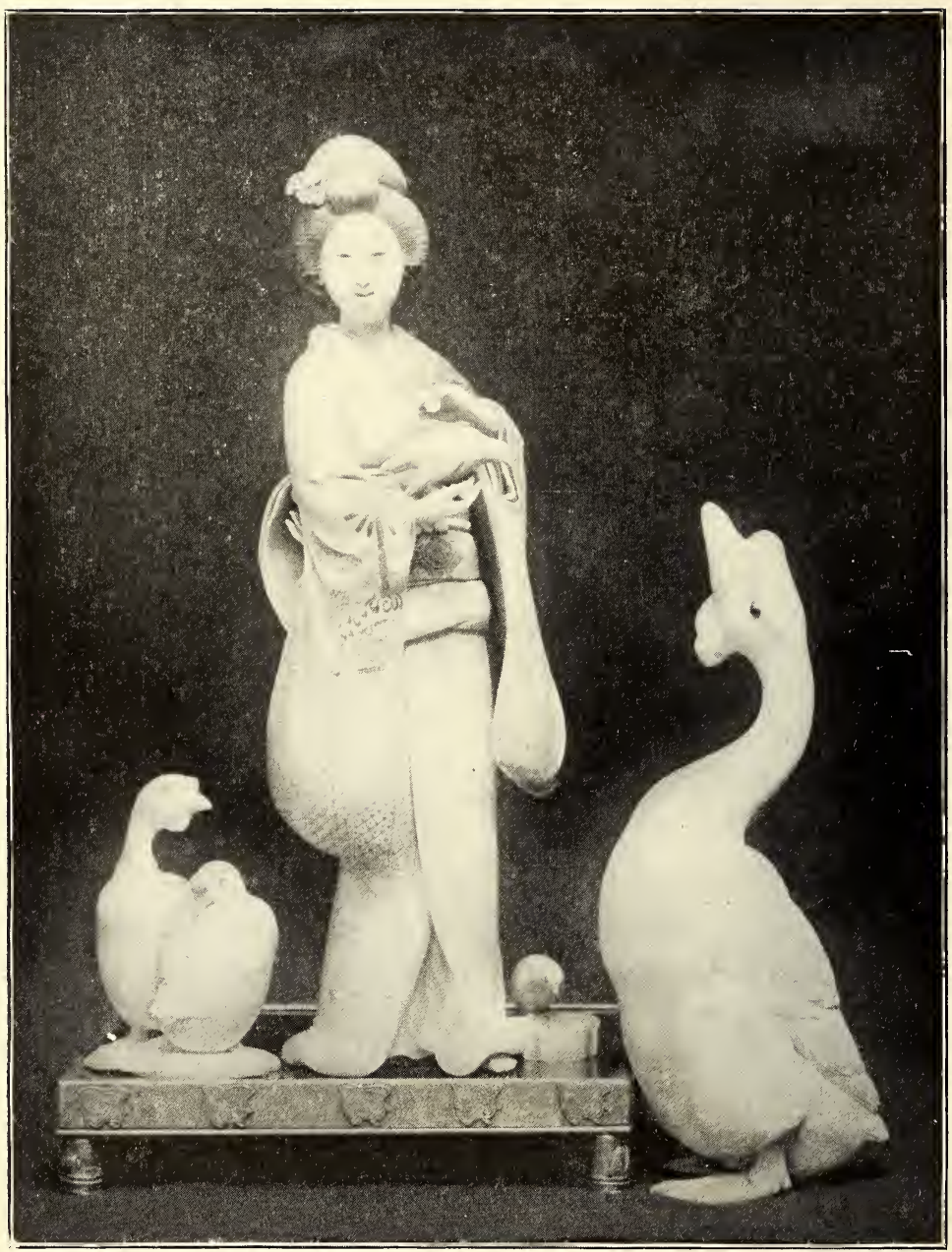

No. 764 .

No. 762 .

No. $76_{3}$. 


\section{IMPORTANT OLD POTTERY.}

753 Öld Karatsu Jar; in form of bag. Thick green, blue and cream glaze. Hard red clay; unusually fine specimen. Height, 7 inches. Date about I6oo.

754 Old Ofuke Dish; oblong with turned edges on two sides. Fine pinkish glaze. Date about I70o.

755 Old Karatsu Jar; beautifu1, pale blue glaze. Date about I6oo. Height, 6 inches.

$75^{6}$ Temmoku Bowl with silver rim; marvellous glaze. Date, I 500.

757 Old Kutani Vase; charming decoration of Howo bird in green and dull red enamel. IIas several bands about the neck and base. Very fine specimen. Height, 8 inches. Date, I725.

$75^{8}$ Seto Glaze Satsuma; gorgeously rich green, red and cream glaze. Very rare specimen. Made by Hoju of Satsuma. Height, 9 inches. With teakwood stand. Date about I 700 .

759 Old Kutani Incense Burner; green and red enamel with silver. Made by Goto Saijiro. Date, Í́50. Height, 5 inches.

760 Kinkwazan Vase; superb brown glaze. Made by Toshiro, Seto. Date about ${ }_{5} 500$.

76I Hagi Bowl; gray glaze with beautiful shade of pink. Made by Raku Rionue. Date, I72o.

762 Ivory Carving; maid feeding pigeon. Graceful carving from one piece of ivory. The expression on the maid's face is particularly sweet. Such fine workmanship is seldom attained by the best ivory carver. Carved by Issin. Received first medal from Tokio Carving Association, 1897. Height, Io inches.

763 Ivory Carving; goose with neck upstretched. The bird is perfectly carved in every detail. Height, 7 inches. 
764 Ivory Carving; two geese. Carved by Sekisai. Signed.

$7 \sigma_{5}$ Imari Porcelain Jar; peony blossoms in delicate blue enamel under the glaze; dull red enamel sround. Very fine specimen. Height, 7 , I-2 inches.

760 Hirado Bowl carp painted in blue under the glaze. Diameter, 7 I-4 inclies.

767 Rak11 Tea Bowl; rich glowing red with splash of green. Made by Raku Rionue. Date, I720.

768 Old Kutani Vase; group of gold fish painted in coral red enamel and gold. Has fine brocade border abont the neck, shoulder and base. One of the earliest specimens and one of the most important porcelains in the collection. Date about 1650 .

769 Old Hirado Bowl; blue and white. Scroll design in blue on white. Fine old specimen. Date, г650.

770 Yeiraku Bowl; irregular form; delicate blue and white sketches. Unusual specimen. Date, 1800 .

77I Embroidered Silk Hanging; wistaria flowers and Japanese chin dog. Has brocade silk border. Made by Nomura of Kioto.

772 Embroidered Silk Square; bamboo and sparrows.

773 Embroidered Silk Square; chrysanthemum design.

$77+$ Embroidered Silk Square; conventional Kiri leaves.

775 Old Imari Jar-Porcelain Tea Jar-pine, bamboo and plum blossoms painted in blue and red enamel nunler. the glaze. Minute border decoration and conventional peony leaves are very delicately done-seldom seen in Imari. Date about I6oo. Imari Ware is a favorite of His Imperial Japanese Majesty, and such a fine specimen seldom comes into the possession of the collector. One of the most important Imari pieces in the collection. Height, I9 inches. (See illustration.)

776 Old Jmari Jar. This jar was malle during the same period as No. 775, but is without doubt a better specimen. Most important Tmari jar in the collection. Height, 19 inches. 


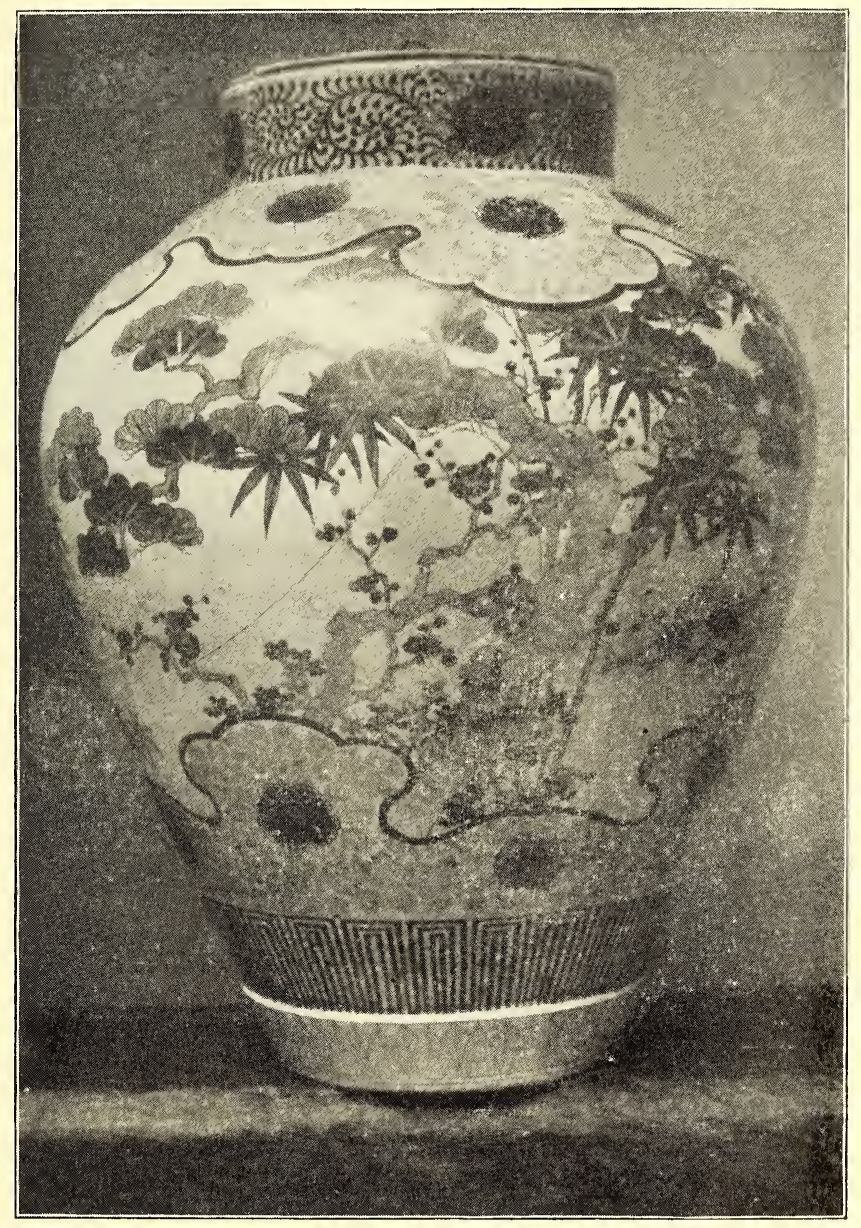

No. 775 . 




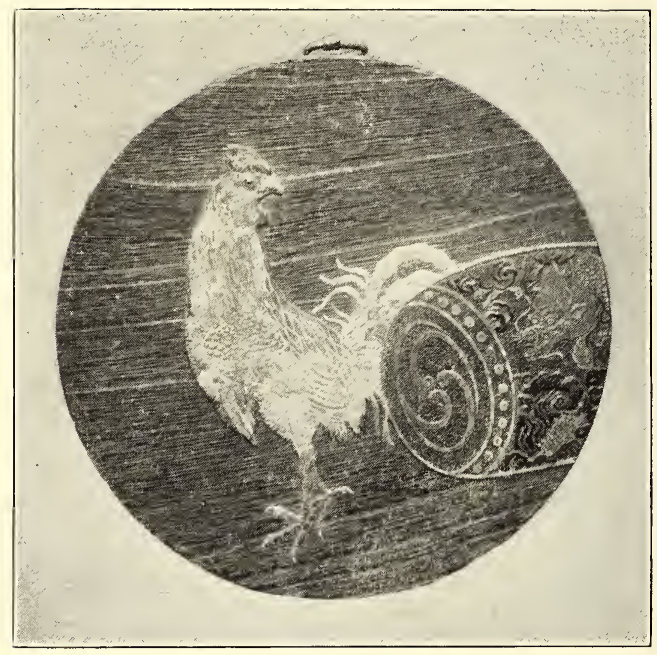

No. $7^{8} 3$. 
777 Old Hirado Incense Burner; known as "Itome" Hirado, or Thread Decorated Hirado. Delicate raised thread lines in blue enamel under the glaze. Has a perforated cover. Date, I750.

770 Imari Bowl in form of chrysanthemum. Imperial chrysanthennm crest in the centre. Bate about 1980.

779 Old Imari Shrine Bottle; tall, slender neck; exquisite form. Conventional floral design painted in various enamels. Very rare specimen. Date, I7oo. Height, $9 \mathrm{I}-2$ inches.

780 Mate to one above, No. 779.

78 I Mitsulhiro Bronze Vase; swallows in relief. Very fin: green bronze. Made by Mitsuliro, celebrated bronze maker. Height, 8 inches. With teakwoosi stand.

782 Mitsuhiro Bronze Vase; flying bats carved in relief. Fine green bronze with teakwood stand. Height, Is inches.

783 Ritsuwo Inlaid Placque; cockerel and Imperial drum inlaid on one side and musical instruments on the other. The inlaid work is pottery, an art attained by Ritsuwo alone. Date 1650. Mark, Ritsuwo. (See illustration.)

784 Pottery Fudo Fighire by Ritsuwo. Ritsuwo stulied the work left by Koyetsu and his Keranic work is indeed wonderful. Very rare specimen. Mark, Kwan (Ritsiwwo's Seal). Date, 1650. Height, 14 inches.

785 Olal Satsuma Teapot; plain white clay, fine crackle. Date, 1780 .

780 Kioto Teapot: with silver handle. Pale yellow glaze. Made by First Hozan. Date, i780.

78 7 Maizan Satsuma Teapot; exquisite form with minute decoration in gold. Work done with the use of a magnifying glass.

-\$8 Awata Teapot; fine ivory-like quaity made by First Kinkozail. Date, iz8o. Mark on tiic cover. 
789 Zeshin's Lacque: Tray; Zeshin is known as Meiji Era Korin. His work has a pectuliar delicacy and superb coloring. The lacquer is a deep green, unpolished; the plum blossoms are inlaid in silver. The blade of the knife is so skilfuliy worked out that it looks as if the real rust metal itself were inlaicl. One of the most remarkable specimens. Signed, Zeshin on the knife blacle. Date about I840. (See illustration.)

790 Embroidered Silk Temple Hanging; sacred Howo birds and Kirin's in chrysanthemum garden; rapids and various flowers embroidered in relief. Whole space of $7 \mathrm{ft} .7$ in. by $5 \mathrm{ft}$. 4 in. is covered with needlework. Has costly gold brocade border. Made by Nomura, Kioto.

791 Embroidered Silk Square; conventional dragon and cloud. Has silk brocade border.

792 Embroidered Silk Square; Howo bird and Kiri leaves. Border of brocade.

793 Embroìcered Silk Square; Howo bird and chrysanthemum embroidered in relief. Border of gold brocade.

794 Two-fold Painted Screen: several compartments painted by famous Shijio School Masters. Typical screen used in Japanese home. Each panel measures $5 \mathrm{ft}$. 4 in. by 2 ft. 6 in.

795. Painting on silk by Hoyen. Arashiyama of Kioto in spring. Has genuine gold mat.

796 Painting on Silk; view of Yamashima. Charming Japanese rural landscape.

797 Painting on silk by Hoyen; view of Oiso Beach.

798 Painting on silk by Hoyen; sparrows in field of ripened rice.

799 Painting on silk by Hoyen; Aarshiyama in moonlight.

800 Large Shigaraki Jar; rich Namako blue glaze over conventional grass pattern carved in relief. Height, 34 inches. 


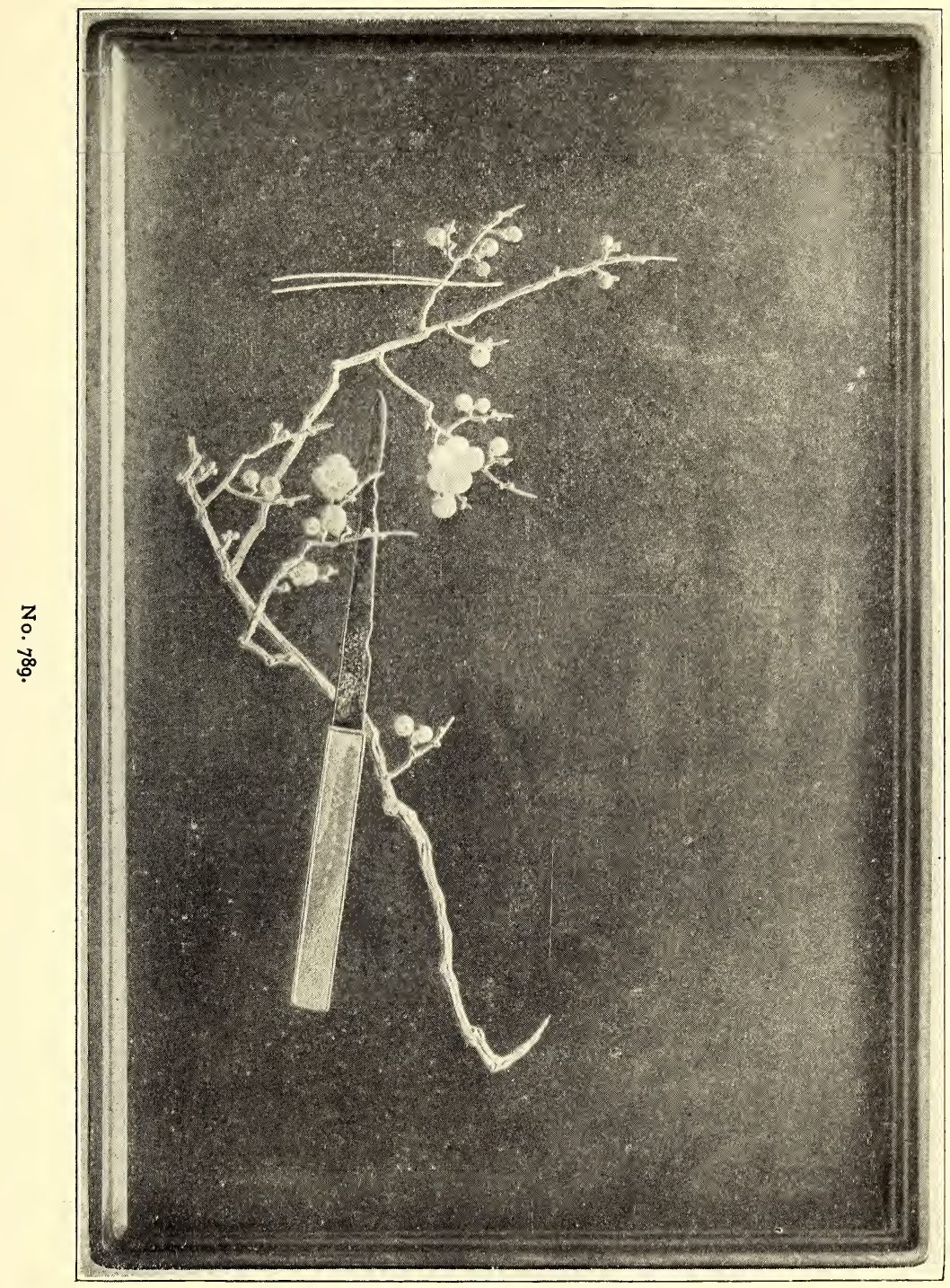





\section{ORDERS EXECUTED WITHOUT CHARGE.}

\section{Eighth Day's Sale--Friday, April 29, at 3.}

8o I Large Six Fold Painted Screen; by Kagawa Hoyen. Corean tiger leaping the valley. Wonderful force and energy portrayed in the tiger. Kagawa Hoyen was born in Kiotoin, I820. He was to have inllerited the title of Baron from his father, Baron Kagawa, but the artistic instinct in him was so strong that he renounced his heritage and became a painter. He studied first with the famous Shibukawa Bunrin and later with celebrated Giokulio. He has been the instructor of painting in the Kioto Art School for more than fifteen years. His work is highly regarded by modern painters.

802 Painting on silk by Hoyen; view of Kamo River. Has genuine gold mat.

803 Painting on silk by Hoyen; view of Seta bridge. Charming landscape.

So4 Large painting on silk by Hoyen; crows on branch of blossoming cherry tree. He has originated a style of his own, although having absorbed much from Bunrin.

\section{IMPORTANT BRONZES.}

805 Tanzan Covered Jar; cylindrical, with deep peacock blue glaze; children at play, in colored enamels. Mark, Tanzan.

806 Bronze Deer by Unboku; beautifully chiselled. Date, I8oo. Height, 7 inches.

8o7 Bronze Vase; in form of carp, by Kamejo of Nagasaki, celebrated woman bronze caster. Date, I780. Height, I 2 inches: 
808 Green Bronze Jar; conventional carved Karkusa border. Beautiful patina. Date, I7oo.

809 Bronze Vase; two turtle form the ears; conventional border. Height, io inches. 400 years old.

8Io Bronze Jar with Cover; finest quality of green bronze. Frog in relief forms handle of cover. Date, I6oo. Height, 7 inches.

\section{FOUR PORCELAIN GEMS.}

8I I Hirado Bowl; low, with curled edge. Beautiful Chinese medalion pattern in charming blue and red glaze. Delicate coral red border about the rim. Most important porcelain in the collection. Height, 2 inches; diameter, 6 inches. With teakwood stand. Date, I 700.

812 Imari Incense Burner, with solid silver top. Made by Kakiyemon about i66o.

8I3 Old Imari Bowl; scalloped edge; centre decorated with Chinese landscape, surrounded by deep border of storks on rich coral red ground. Outside decoration. Storks in colored enamel. One of the rarest specimens of Imari in existence. Date, i6go. Diameter, 9 inches.

8I4 Old Imari Teapot; another glorious specimen. Cover represents chrysanthemum blossom. Date about 1680.

\section{IMPORTANT BRONZES.}

8I5 Ancient Bronze Bowl; rich cloudy green and red color. This bronze is at least 800 years old, and is beautifully preserved. This is one of two most important bronzes in the collection. Diameter, I3 I-2 inches. Height, 8 I-2 inches.

8I6 Bronze Jar with Coyer; in form of helmet, inlaid with gold and silver. 500 years old. 



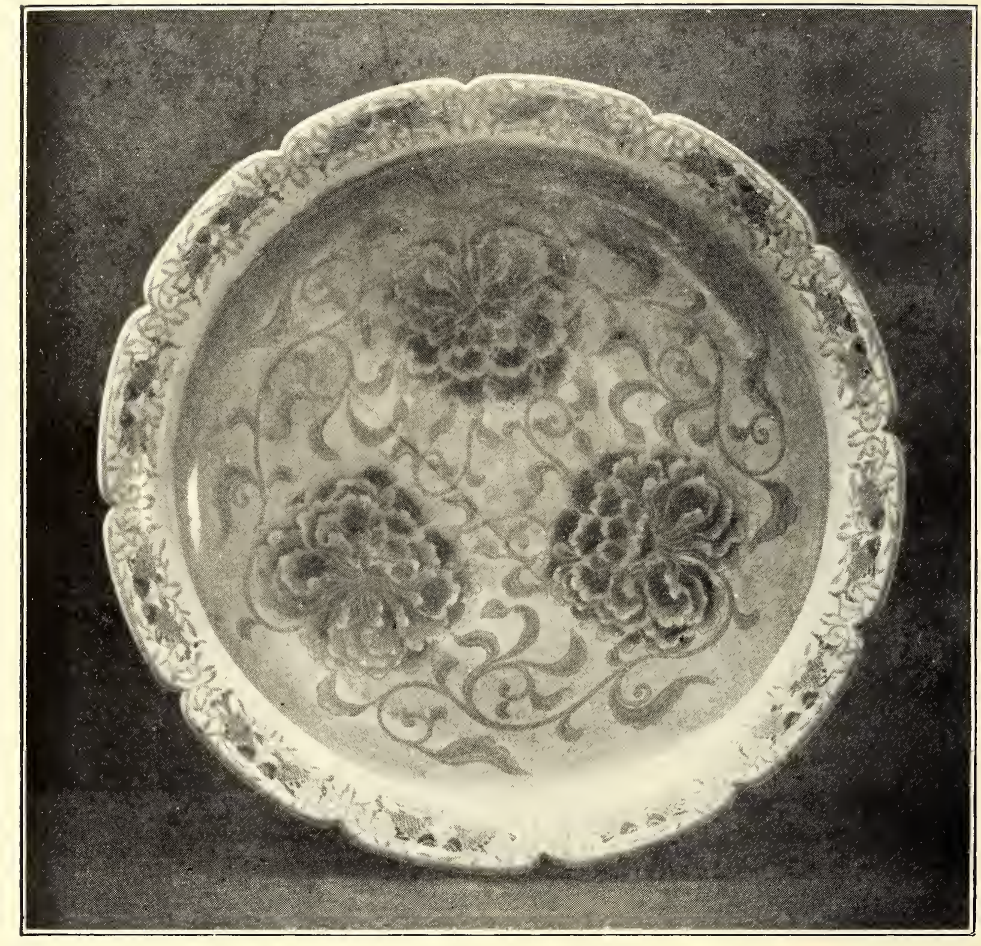

No. 818 .

Showing inside decoration. 



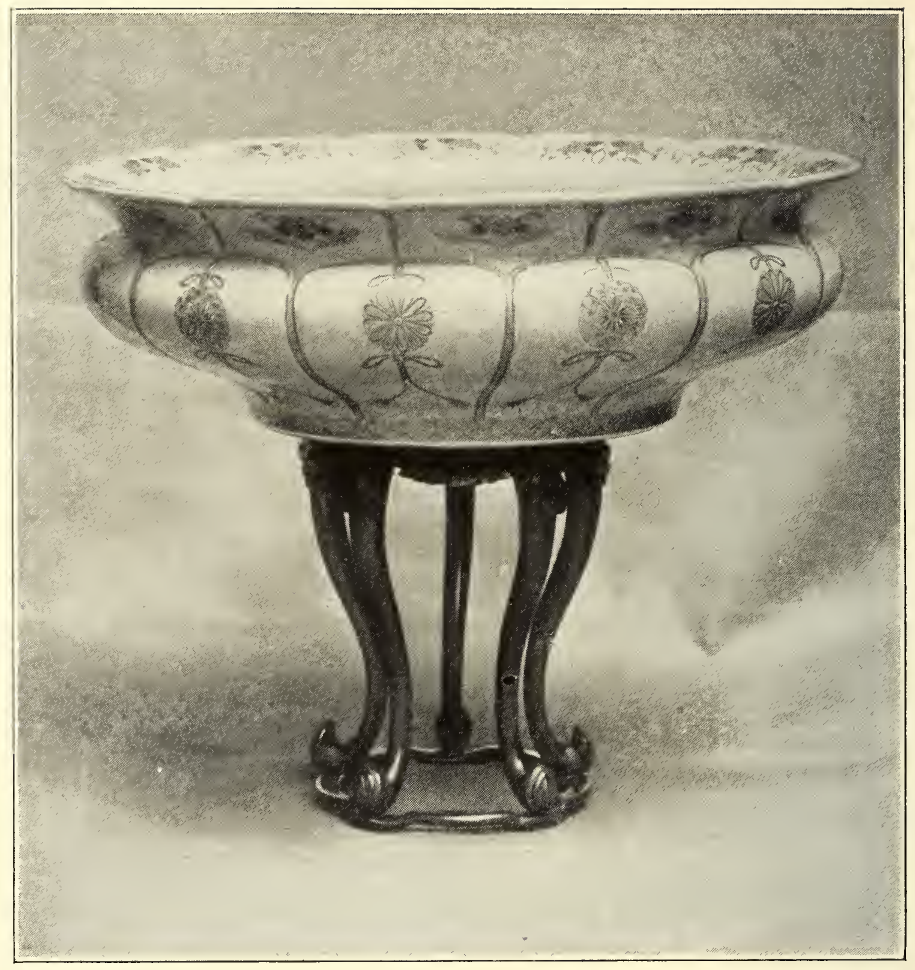

No. 818 .

Showing front and outside decoration. 
8I7 Old Enamel Wine Pot; repousse design partly enameled with green and red. One of earliest specimens of enamel work. Date, i6oo.

\section{NO'TE.}

The quality of genuine decorated Satsuma is hard white clay with hard, marble-like crackled glaze, and is distinguished by its dull red, green and blue enamels with thick gold tracings.

Best early specimens were made about Kwansei Period (I79II 8oo), therefore the term, Old Decorated Satsuma, means, Satsuma at least over eighty years old.

8I8 Old Satsuma Dish; decorated in green, blue and deep coral red enamels. By many Japanese connoisseurs in art this is pronounced to be one of the most glorious decorated Satsumas ever created in the kiln oi Prince Shimazu (the Lord of Provinces of Satsuma and Osumi). Its form, quality and decoration worth for any one to come many miles to see it. It is utterly impossible for the collector to describe how beautiful it is. (See illustration.) One of the gems of the collection. Date about I8oo. Height, 3 3-4 inches; diameter, I 4 inches.

8I $8 \frac{1}{2}$ Satsuma Vase; waves and fishes carved in relief under the glaze. Has elaborate conventional band around shoulder and base. Carved Grecian border round the neck. Splendid specimen. Height, I6 inches.

8I9 Decorated Satsuma Incense Burner, with solid carved silver cover. Round, supported by three legs, hard marble like crackle, decorated with various chrysanthemum flowers in dull red, blue and green enamels. The silver cover is carved perforated floral pattern, very elaborate work. Very important piece. Made about I82o. Height, 9 inches. With teakwood stand.

820 Satsuma Sake Bottle; decoration, lions and peony flowers. Fine, hard crackle. Date, i8oo. With teakwood stand. Height, 6 inches.

82I Satsuma Vase; spray of chryanthemums painted in blue and gold in delicate manner. Has conventional floral pattern round the rim. Date about I830. With teakwood stand. Height Io I-2 inches. 
822 Old Satsuma Incense Jar, with solid silver cover; exquisite design of plum blossom and camellia in delicate blue, green and dull coral red enamels; Grecian border in gold about the neck. Hard, finest crackle. This charming bit of Satsuma is indeed most magnificent specimen ever obtained by the collector. The delicacy of form and decoration is unsurpassed. One of the most important Satsumas in the collection. (See illustration.) Date about I790. With teakwood stand.

823 Satsuma Incense Burner; with perforated cover. Flat form, has thick gold tracing over dull coral red brocade pattern. With teakwood stand. Date, I8zo.

824 Plain White Satsuma Vase; charming elliptical form. Vèry fine hard crackle. Finest white Satsuma in the collection. Height, IO I-2 inches. Has elaborately carved teakwood stand.

825 Awata Sake Bottle; known as Amamori Awata on account of its rain-like stain. Charming landscape painted in blue under the glaze. Very fine ivory-like glaze. One of most important Awata in collection. Date about i7oo. Height, 6 inches.

826 Plain White Awata Jar; beautiful flat form. Warm ivory-like quality, with fine crackle. Best Awata ware in the collection. Date about I 7oo. Has elaborately carved teakwood stand. Height, 6 inches.

\section{IMPORTANT LACQUERS.}

827 Lacquer Writing Case; decoration, cow and cowboy, designed by Kano Motonobu. Date about I620.

828 Lacquer Screen; one side has decoration bridge and weeping willow. Other side, two warriors on beach. Height, I3 inches. Made in Ashikaga era, I449I45I. Very interesting.

829 Lacquered Basket, in three compartments; handle and body of basket a beautiful decoration in red and gold lacquer. Height, I3 inches. Date about I6oo. 


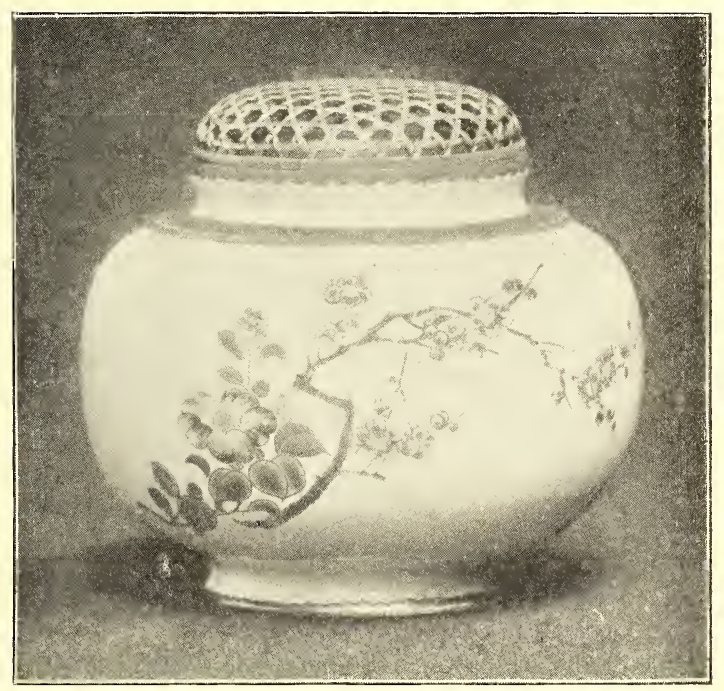

No. 8:2. 

830 Gold Lacquered Bow and Arrow Case, with bow and arrow; spear bearer in relief on cover. Inside of box has rich Karakusa pattern in gold lacquer. Bow is trimmed with siiver. Date, I7oo.

83 I Small Writing Case; in form of gunbai fan. Beautifully ornamented with Imperial Kiri crest in gold on brown surface. Ashikaga era. Specimen, I450.

832 Small Lacquer Writing Case; Japanese native camellia and parasol decoration in gold. Fine specimen of Ashikaga lacquer.

833 Crysal Ball; 3 I-8 inches in diameter; perfect specimen. With stand.

834 Crystal Ball; 2 I-8 inches in diameter; perfect specimen.

835 Crystal Ball; 2 inches in diameter; perfect specimen.

\section{NOTE.}

Nonomura Ninsei. Among all Japanese Keramic Artists there is none who had so many imitators as Ninsei, since his work was greatly admired and sought after by collectors. But the expert can distinguish his works by the stamped signature "Ninsei," the peculiarly delicate crackle, the unusual form and technical skill which it is impossible to imitate. He built his kiln at Sannenzaka, near Kiomizu, Kioto, and made war during Kwan-ei Period (I6241643). We regard Koyetsu, Kenzan, and Ninsei as the monarch potters.

836 Ninsei Jar; decorated with dark silver wave pattern and Hoshi-no-Tama or precious stones in dull red, green and yellow enamels. It at once resembles the finest Satsuma. The inimitable skill portrayed in this noble specimen no other Japanese keramic artist can surpass. It will take weeks of study to appreciate its wealth. Fine crackled glaze. Has original lacquered box and silk cord bag. Mark, Ninsei. Date about I63o. Height, Io I-2 inches. (See colored illustration.)

837 Ninsei Tea Bowl; Lotus leaves painted in black under the glaze and water bird decorated with red and green enamel in charming manner. Fine specimen. Date about I640. 
838 Ninsei Incense Burner; God of Happiness opening the bag of wealth and two infants playing together. Height, 5 inches. Date about I630.

839 Ninsei Bottle; beautiful form. Decorated with red and green enamel. Fine soft crackle. Date, I640. Height, 7 inches.

NO'TE.

Korin and Kenzan. These two remarkable brothers who were destined to be "Monarchs of Art Creation" in Japan from early part of Genroku to Hioho Period (I688-I715), were born in Kioto. Korin, the elder, first studied painting in Kano School, and later followed Sotatsu; but his celebrated lacquer works are due to an intense admiration and study with an aim to equal, if not surpass, the work of the famous Honnami Koyetsu (I600 A. D.).

Kenzan, the younger brother, possessed great genius in pottery making, and his countrymen with one accord rank him with Nomomura Ninsei.

840 Gold Lacquer Tea Jar; design of pine tree and storks in relief inlaid with Mother of Pearl. Very fine. Good lacquer. Signed, Hokio Korin. Date, I6oo. Height, 4 inches. (See illustration.)

84I Gold Lacquer Tea Jar; design of native clover partly inlaid with Mother of Pearl. Signed, Hokio Korin. Date, I6oo. Height, $3^{\mathrm{T} / 4}$ inches.

842 Square Lacquer Tray; spary of iris flowers inlaid in Mother of Pearl and pottery, and decorated with gold lacquer. Signed, Hokio Korin. Date, I6oo. Io inches square.

843 Gold Lacquer Tea Jar; beautiful landscape decorated in Chinkin and Togidashi gold lacquers. Glorious coloring. Made in Ashikaga Reign 1450. Height, 3 inches.

844 Kenzan Bowl with original box; Ogata Kenzan first made his pottery at Narutaki Village, north west of Kioto Palace, hence his name, Ken (north west) zan (mountain). Later he went to Iria Village, a suburb of Tokio. Outside decoration, Tatsuta maple in fall. Rich glowing sunset through the maple leaves. Inside decoration, cherry blossoms scattered here and their signifying Yoshino in spring. (Tatsuta, a place famous for its beautiful maples; Yoshino for its blossoming cherry trees.) Signed, Kensan. Date about I7I 5 . 


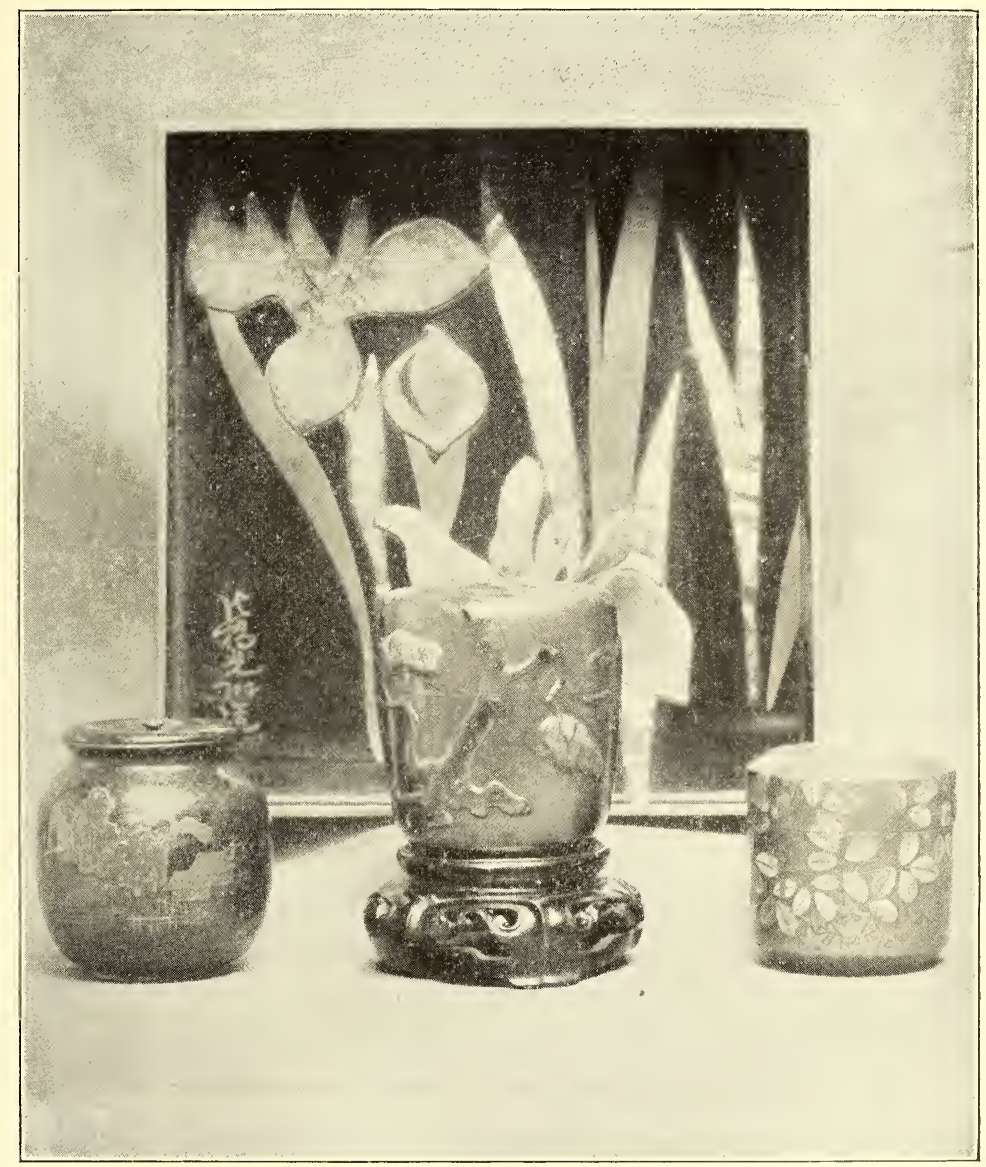

No. $8_{12}$.

No. 843 .

No. 840 .

No. 84 I. 




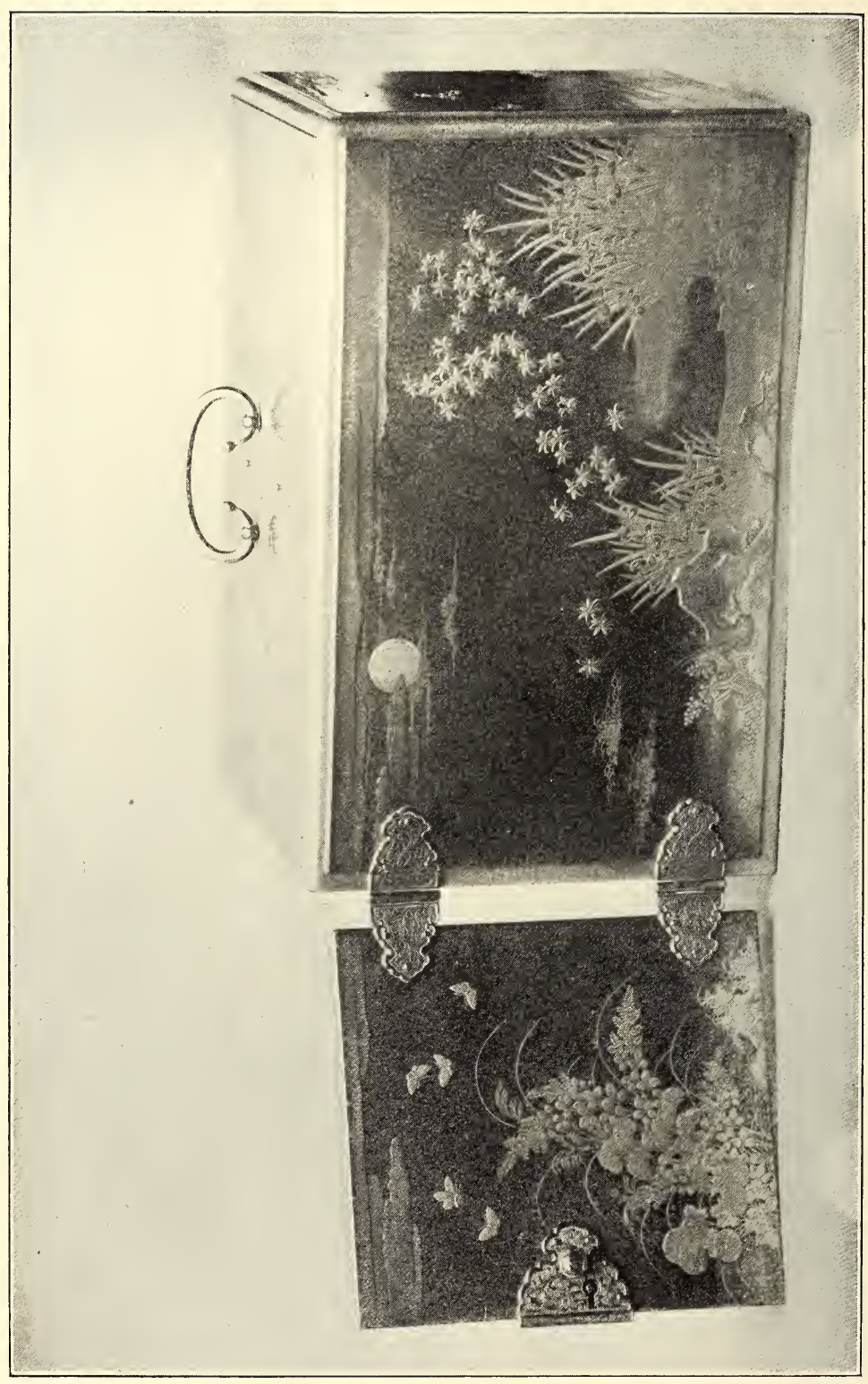

유
z
z 
845 Kenzan Bowl; floral decoration; Iris, chrysanthemum, dandelion and various other spring flowers. In colored enamels under the glaze. Fine specimen. Signed, Kenzan. Date, I7 I5.

846 Kenzan Dish; irregular form. Chrysanthemum decoration in blue and brown enamels under the glaze. Made at Iiria, Tokio. Date, I720.

847 Kenzan Bowl; figures in Chinese Saints painted in various enamels on rich coral red ground. Mark, Kensan. Date, i7 Iо.

848 Six Fiold Gold Screen, by Nomura Sotatsu. After earnest study in Kano and Tosa Schools, Sotatsu in early part of Kwan-ei ( 1630$)$, completely throws off the tyranny which has tended to narrow the limits of painting, and asserts himself as leader in a broader and more original style of painting. The world knows Korin, but who can be ignorant of the great master, Sotatsu, to whom his glory is due. This screen, preserved for the last two centuries and a half, is a truly splendid work of Sotatsu, about i635. What a noble painter of flowers! White plum tree in blossom with vine twining about the trunk. Spray of brilliant poppies and various other flowers painted in charming groups. Height, 5 feet, 7 inches.

849 Mate to above (848); Sotatsu's manner of obscuring a part of the flowers in a golden mist is wonderful.

\section{IMPORTANT GOLD LACQUERS.}

850 Old Gold Lacquer Cabinet; decoration, Mikado's garden showing the season's flowers. The cabinet presents in its panels and other parts specimens of every kind of the best gold lacquer work, comprising Kinji, Nashiji, Hirame and Takamakiye. Made for Tokargawa in Kwanyei Era (I624-I643). Height, 5 inches. Length, 8 inches. (See illustration.)

85I Gold Lacquer Box in form of Japanese harp; gorgeously decorated with gold on the inside. Design, bamboo and rock. Made by Kinkosai, i 700. 
852 Gold Lacquer Box in form of three wine jars; beautiful specimen. Date, i650.

853 Gold Lacquer Box in form of fan; ferns and tachiband flowers in relief over superb Nashiji lacquer. Date, I700.

854 Gold Lacquer Tea Jar; decoration, maple leaves partly inlaid with Mother of Pearl. Date, I6oo.

855 Gold Lacquer Smoking Set (used in palace); decoration illustrating summer scenery near Kamogawa River in polished gold and black. Designed by Matahei; made by Morishige, I720.

856 Gold Lacquer Box; decoration, ducks in relief. Beautiful Nashiji lacquer inside.

857 Incense Case-gold lacquer-in form of suit of Armor; fine old specimen. Date, I6oo.

$85^{8}$ Standing Figure of Kwan-non; carved from sandal wood and lacquered. 300 years old. Height, I2 inches.

859 Red Lacquer Bucket; delicate spray of bamboo in gold on red lacquer. Bands of black, gold and Nashiji lacquer about the vase. Height, I I inches.

860 Old Lacquer Compartment Box (in three sections); octagonal. The entire surface of the box is covered with a conventional floral design inlaid with Mother of Pearl. A truly magnificent specimen. Date about i6oo.

86I Old Lacquer Tray-otagonal-a panel in the centre and border about the rim; has conventional floral design inlaid with Mother of Pearl. The rest of the tray is entirely covered with a Mosaic design inlaid with tiny bits of Mother of Pearl on black lacquer. An exquisite piece of workmanship. Date about I600.

862 Old Box Inlaid with Pearl; diamond shape. Sacred Kirin inlaid with Mother of Pearl on the cover. Body of the box has beautiful inlaid Mosaic design. Date, I 500 . 


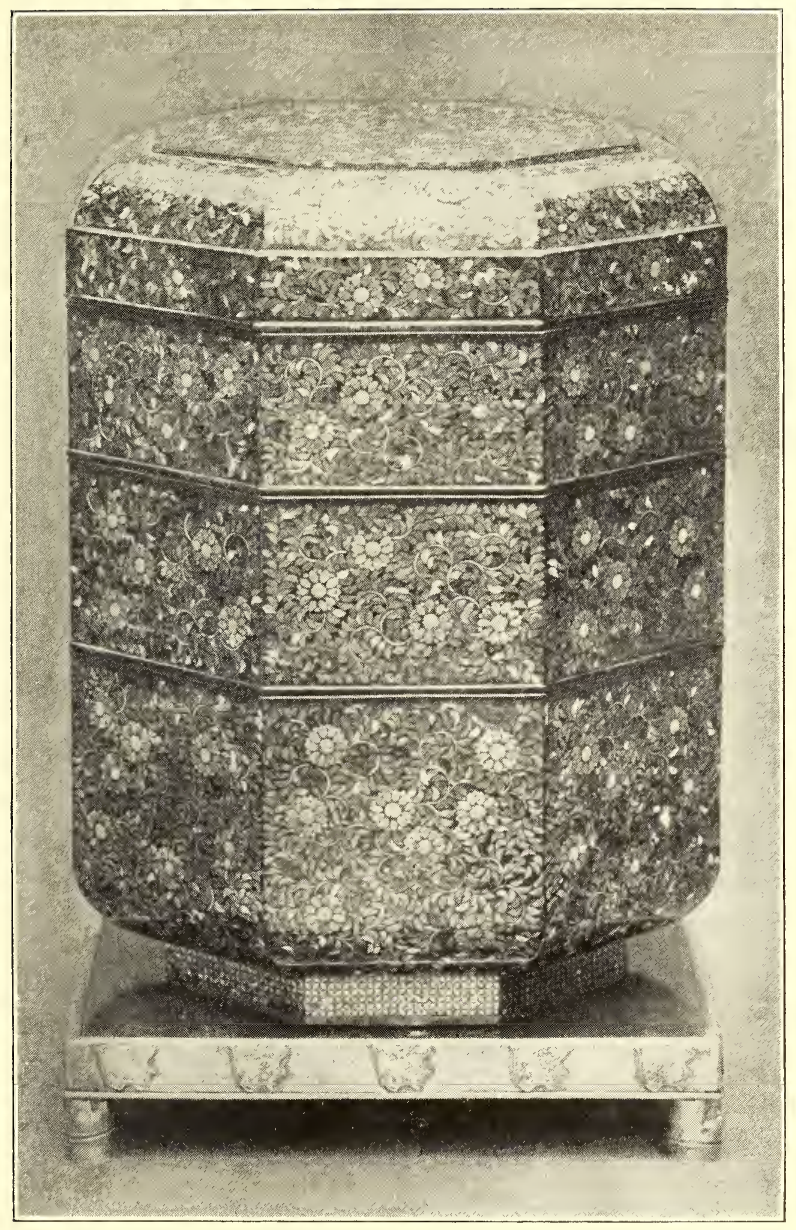

No. 860 . 

863 Old Box Inlaid with Pearl; entire box is decorated with conventional floral design inlaid with Mother of Pearl. Age has changed the pearl to rich amber yellow. Size, I4 inches by Io inches. 600 years old.

864 Lacquer Sake Bottle, known as "Kamakura Bori"; date, I500. Height, II inches. Unique specimen.

865 Ivory Carving; Japanese Wolf Dog. Beautiful carving from a solid piece of ivory. Eyes inlaid with precious stones. Carved by Giokudo. Signed, Specimen. Height, 3 inches. Length, 6 inches. Has beautiful lacquer stand ornamented with silver.

866 Ivory Carving; Wolf Dog. By Giokudo.

867 Tiny Ivory Carving; Japanese Wolf Dog by Giokudo.

868 Vase-Enamel on Silver; imperial yellow with delicate brocade border at top. Shakudo rim about the top and base of vase. Height, $7^{\mathrm{T} / 2}$ inches. By Namikawa Sosuke, celebrated enamel maker. With teakwood stand.

869 Enamel Vase; Fuji Mountain and clouds on pale gray and white enamels on deep gray ground. Beautiful specimen. Height, $7^{1 / 2}$ inches. Made by Hattori, Nagoya.

Three Gems by Makuzu Kozan.

870 Kozan Vase; beautiul form. Decoration, dragon enshrouded in glorious pleach bloom cloud. Height, $6 \frac{1}{2}$ inches. One of the most glorious specimens ever brought to this country. With teakwood stand.

87 I Vase by Kozan; dragon in Kuriume gray on brilliant coral ground. Height, $8 \frac{1}{2}$ inches. With teakwood stand.

872 Kozan Vase; beautiful form, tall, flaring at top. Dragon painted in brown enamel under pinkish gray glaze. Height, 8 inches. With teakwood stand.

873 Embroidered Silk Hanging; rapids of Fuji Kawa and group of stork. Cryptomaria trees on either bank embroidered on beautiful greens; the foaming water of the rapids and storks in white. Temple of $\mathrm{My}$ nobu in the distance. Exquisite needle painting by Nomura, of Kioto. 
874 Red Silk Gown; fine Shibori crepe, lined with Momi silk. Beautiful red with white floral pattern.

875 Pink Silk Obi; cherry blossoms in white stincil on pink ground.

876 Kioto Bowl by Second Dohachi; decoration, native white camellia and leaves beautifully planted under the globe. Unustial specimen.

877 Awata Figure; two men dancing with drum and fan. Height, 7 inches. Date, I80o.

878 Old Awata Bowl; hexagonal, conventional cloud painted in blue, green and red enamel. Date about izoo.

879 Kenzan Covered Dish; decorated with bands of red, green and blue enamel. Signed, Kenzan.

S8o White Awata Bowl; beantiful form, with fine crackle. Date, 1800.

88I Seto Bowl; light brown glaze with deep brown marking. 200 years old.

882 Old Stone Lantern; cut from fine Mikage granite. Used in gardens and temple yard. This brought from an old garden in Kioto. Height, 5 feet, 8 inches. (See illustration.) 300 years old.

883 Huge Bronze Vase; ten beautifully wrought border designs encircle the vase. The most exquisite specimen in form and color ever brought to this country. (See interesting illustration.)

884 Yukimi Stone Lantern; low, with broad flat top; stands on four legs. This form of lantern is a favorite for Japanese gardens, especially during the winter, because the broad top holds a great quantity of snow, giving it a very picturesque appearance. Hence the name "Yukimi" (snow scene) lantern. Height, 4 feet.

885 Old Kaga Incense Box; elaborately decorated in coral red enamel. 200 years old. Mark, Fuku.

886 Celadon Incense Jar with Cover; glorious specimen. Mark, Kitei.

887 Ohi Raki1 Incense Jar; beautiful green. With teakwood stand. 


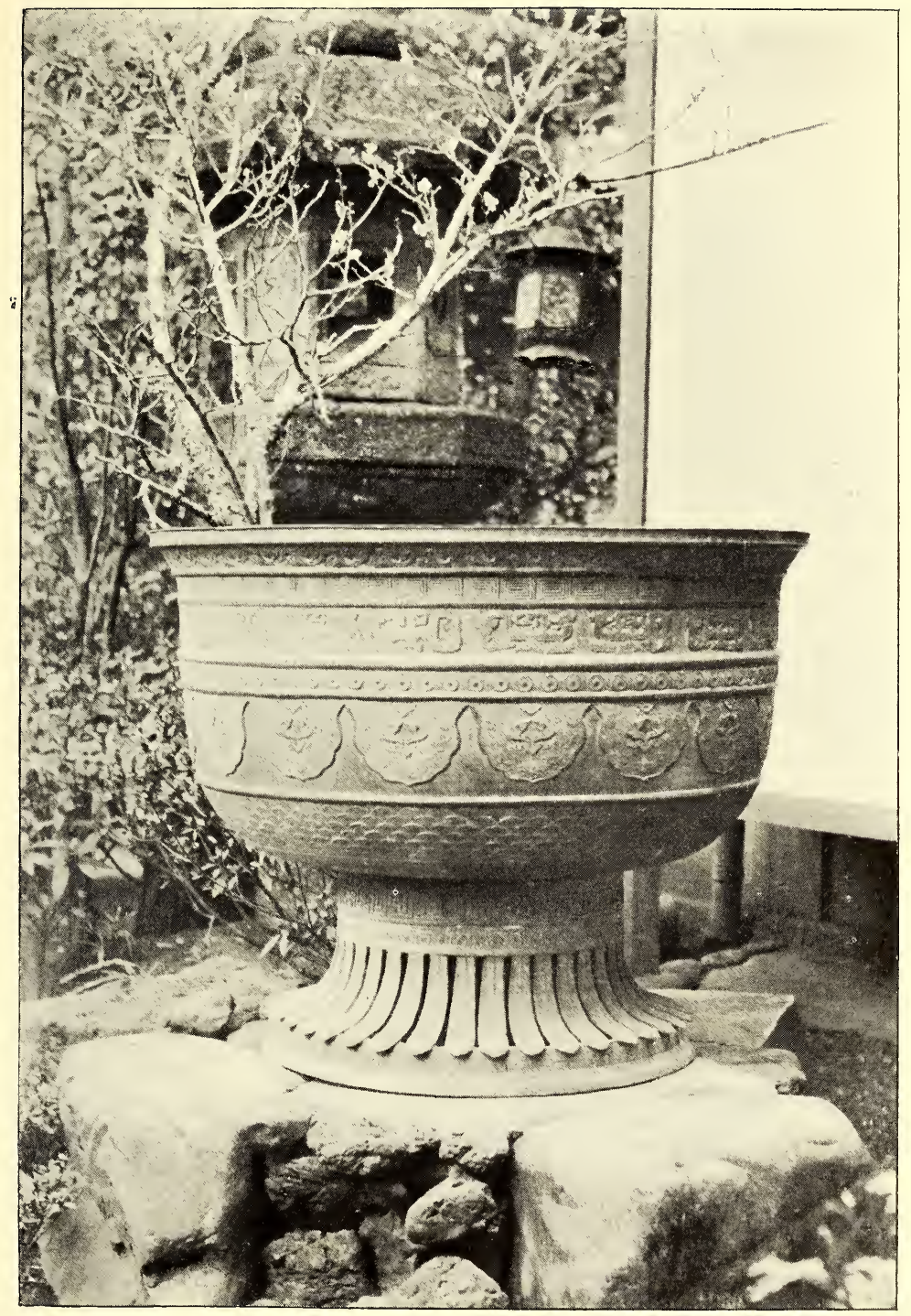

No. 882 .

No. 883 . 

888 Old Imari Tea Jar; coral red decoration. 250 years old.

889 Porcelain Vase; deep purple, with misty green markings.

890 Yeiraku Incense Jar; in form of gourd. Delicate gold decoration on deep coral red. Ioo years old.

89I Satsuma Tea Jar; beautiful crackle. Rare specimen.

892 Kozan Bottle; signed specimen.

893 Small Satsuma Jar with Cover. Ioo years old.

894 Yeiraku Cup and Saucer; fine brocade decoration. Signed specimen.

895 Old Kaga Bowl; conventional decoration. Gold and silver on coral red.

896 Peach Bloom Jar; with three legs. 300 years old.

897 Kaga Incense Box; in form of duck. Mark, Fuku. Fine specimen.

898 Embroidered Silk Temple Hanging; eagle and two dragons in delicate colored silks. Several conventional clouds in subdued colors. Lower part has delicate blue wave pattern. Costly brocade border. Size, 9 feet by 7 feet.

899 Embroidered Silk Square; stork in chrysanthemum garden. Size, 5 feet by 5 feet.

900 Embroidered Silk Square; conventional chrysanthemum design. 


\section{ORDERS EXECUTED WITHOUT CHARGE.}

\section{Extra Sale (Eighth Day) Friday, April 29, at 3.}

536 Old Buddha and Stand; beautiful expression. Height, 3 feet. Date, i67o.

537 Temple Canopy; black lacquer frame lined with gold. The four hanging draperies at sides and four banners at the corners are made of costly Chakinran brocade, with flat, real gold thread, woven into the silk. It is very rare, for the reason that this particular class of silk was burned by the natives to realize the gold in it. Just as great a number of gold lacquer objects were destroyed at the time Imperial Restoration, 1867. This canopy was in the inner shrine of Saga Temple in suburbs of Kioto. Rarest and most graceful form of canopy ever obtained. One of the gems of this collection. Date about I 700.

538 Gold Brass Tokko Emblem of Meditation; fine specimen. Date, I750.

539 Embroidered Silk Square; cryptomeria forest. 3 feet by 3 feet.

540 Embroidered Silk Square; sparrows and bamboo. 2 I-2 feet by 2 I-2 feet.

54I Embroidered Silk Square.

542 Red Lacquer Temple Cabinet; rich red lacquer, with gold floral decoration carved in relief. Four doors open on hinges. Inside is lined with gold. Length, 58 inches. Height, 23 I-2 inches. Depth, I8 inches. Date, i76o. 


\section{ORDERS EXECUTED WITHOUT CHARGE.}

\section{Ninth Day's Sale-Saturday, April 30, at 3.}

\section{IMPORTANT PRINTS.}

90I Large Color Print by Shunman; travelling party enquiring the way. Date, I792. Fine specimen by Shunman.

902 Color Print by Yeishi; group of ladies in a boat. Date, I780.

903 Color Print by Yeishi; dancers and musicians. Date, I780.

904 Color Print by Yeishi; women watching a monkey. Date, I780.

905 Color Print by Haranobu; figure of woman and God of Happiness. Date, iz6o.

906 Small Color Print by Kiyonaga: festival of Kanda. Beautifully preserved print. Date, I790.

907 Small Color Print by Kiyonaga; group of children at festival. Date, I 590.

908 Small Color Print by Kiyonaga; group of female dancers. Date, i790.

909 Small Color Print by Kiyonaga; female dancer and boy singer. Date, r 790.

9ro Small Color Print by Kiyonaga; scene at the festival.

9II Mitsuhiro Bronze Vase; heron in shower carved in relief on green bronze. Finest specimen.

9I2 Mitsuhiro Bronze Vase; carp carved in relief in green bronze. 
913 Bronze Pigeon (life size); represents pigeon pluming its feathers. Exquisitely wrought.

9I4 Green Bronze Jar; cylindrical. Entire body is covered with conventional border designs carved in relief. Fine quality of bronze; gives a deep ringing tone when struck. With carved teakwood stand. Height, 6 inches. 300 years old.

9I5 Scarlet Bronze Incense Burner; in form of peony blossom. Lion forms handle of cover. Rich, glowing color in petals of flower. 350 years old.

916 Ancient Chinese Bronze; made in Hsuan-ti period, I 426. Low, flat form, with carved dragon decoration. Black teakwood cover with amethyst crystal handle. Height, 5 I-2 inches. Elaborately carved on the botton with signature, Tai-Ming Hsuan-ti, Ninsei.

\section{IMPORTANT LACQUERS.}

917 Koyetsu Lacquer Writing Box; three rabbits inlaid in old metal; mountain in the distance. Delicate grass and distant fog in gold lacquer. Back of the cover has decoration representing rising moon. Koyetsu lived in the early part of the seventeenth century. His artistic talent was at once noble-lofty. No one could approach his skill in lacquer and pottery making. Men like Korin, Kenzan, Ritsuwo and others with one accord, surrender the laurels to Koyetsu. Lacquers like this have never beore been offerd at an auction in this country.

918 Koyetsu Lacquer Writing Case; traveller on mule's back inlaid with Mother of Pearl. The hat is inlaid bronze. Notwithstanding its simplicity one is impressed with the great strength and harmony of composition. Date, I620.

919 Koyetsu Raku Incense Burner; design, moon and grasses. Silver cover. Date, i6zo. 



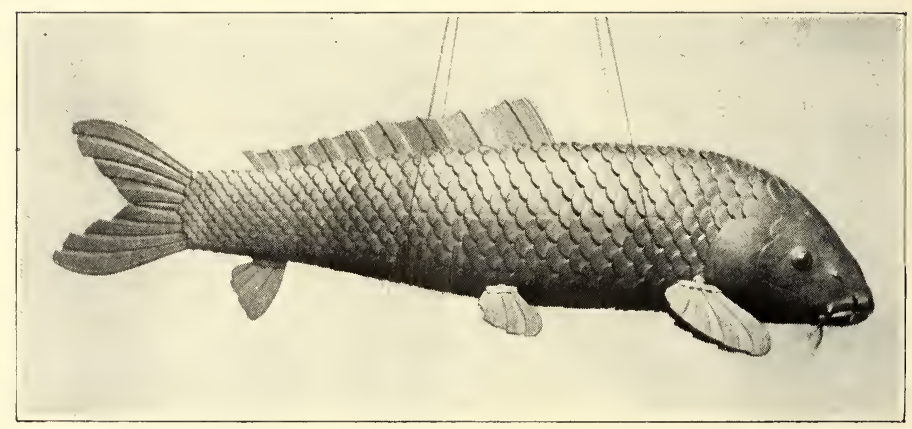

No. 925 . 
920 Korin Lacquered Tea Jar, rabbit on cover inlaid with lead. Body of the jar is decorated with Japanese grass inlaid with Mother of Pearl. Signed, "Korm" under the lacquer on the cover. Date, i6go.

92 I Blue Bizen Incense Burner; monkey sitting on "goban." Very rare specimen. Date, I7oo. Height, 6 I-2 inches.

922 Satsuma Sake Bottle: in form of egg plant fruit; purple glaze with beautiful iridescence. Height, 6 I-2 inches.

923 Plain White Satsuma Bowl; beautiful crackle. Date, I 820.

924 Satsuma Water Jar; decoration, spray of bamboo. By Kwano Tangen.

925 Movable Bronze Carp; by Myochin. Length, 20 I-4 inches. Maximum height, 5 inches. Muneyori Myochin, foremost metal maker in Japan, lived between I600-1650. He excelled in making iron helmets and suits of armor. This carp is one of his most wonderful and excellent work left to this day. Every scale and fin is so put together that when handled the body swings back and forth as if full of life. Mouth, feclers and even the eyes are movable, and the whole is executed in faithful detail. Signed, "Muneyori" under right fin. Weighs only 3 I-2 pounds. Has original lacquer case.

926 Yellow Bronze Incense Burner; boy seated on a gourd stretching his arms. Perfect in every detail. 300 years old. With teakwood stand.

927 Bronze Incense Burner; in form of snake coiled with head uplifted. 200 years old. Made by Joyeki. With teakwood stand.

928 Bronze Koro Carved Standard; representing rock and dragon. Cover is formed by a group of children. Two dragons form the handles. Elaborately wrought bronze. Made, Toun, about I790.

929 Bronze Vase; in form of uplifting waves, bearing a bronze vase on their crest. Date, I8oo. 
930 White Satsuma Teapot; dragon's head forms the spout. Made at Chosa, I73o.

93I Seto Kusuri Satsuma Jar; cylindrical form. Glorious specimen. Height, 9 I-2 inches.

\section{IMPORTANT PRINTS.}

932 Colored Print by Toyokuni; figure of woman with child. Reflection on the black lacquer which forms a part of the screen at her back. It is the most wonderful print made Бy Toyokuni in existence. Purchased from Daikokuya, famous old prints dear in Tokio, Japan, and one of a celebrated collection belonging to that family. Date, i78o.

933 Small Color Print by Harunobu; girl walking with attendant. Date, I760.

934 Small Color Print by Harunobu; hairdessing. Date, I760.

935 Small Color Print by Harunobu; ladies folding cotton. Date, I760.

936 Small Color Print by Harunobu; two ladies on a porch. Date, I760.

937 Small Color Print by Harunobu; lady with dipper. Date, I760.

938 Small Color Print by Harunobu; lady making music. Date, г760.

939 Small Color Print by Harunobu; hairdressing. Date, I760.

940 Small Color Print by Harunobu; three girls wading. Date, i76o.

94 I Small Color Print by Harunobu; child drawing. Date, I 760 . 



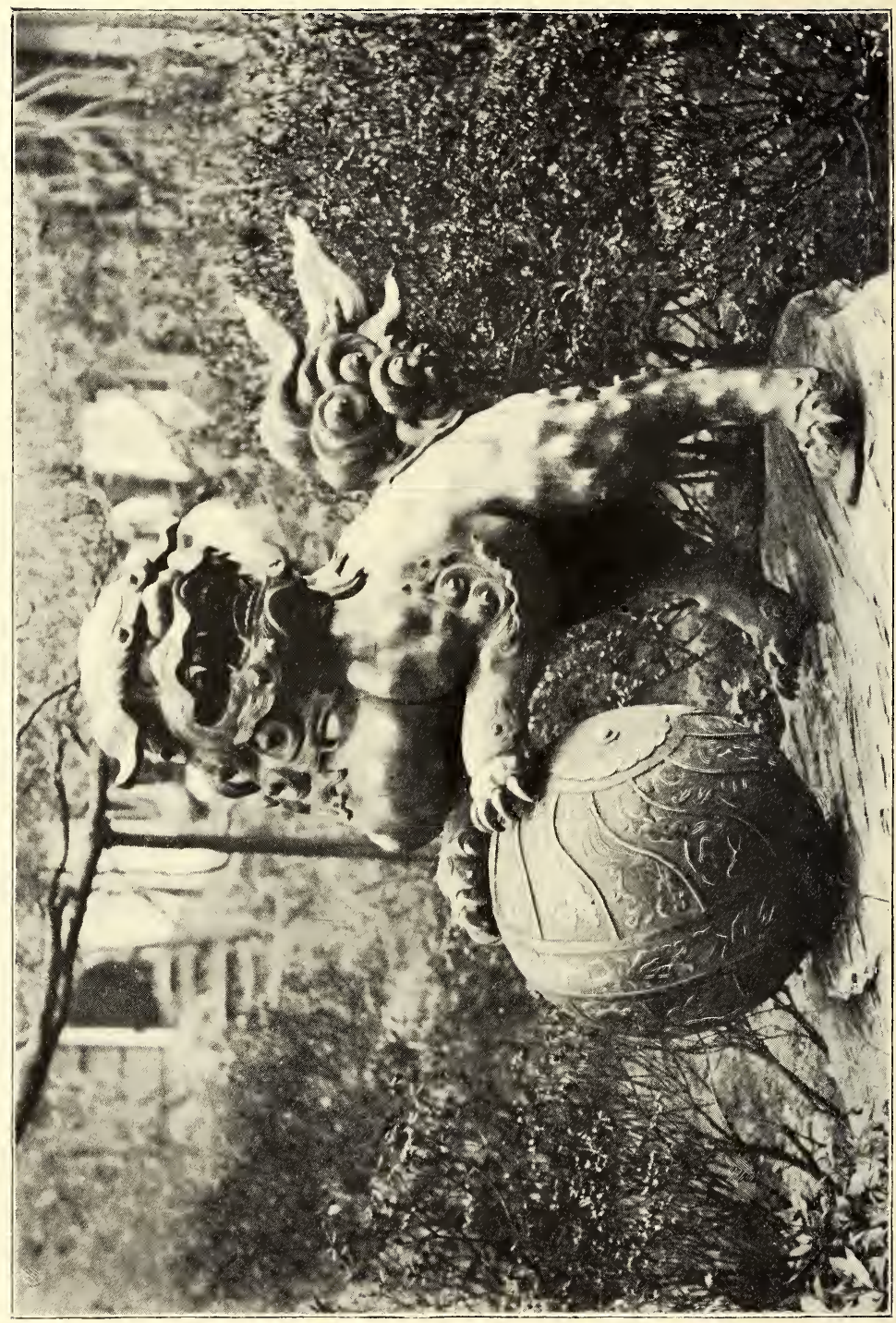

여
$\dot{0}$ 
942 Small Color Print by Harunobu; lady washing dress. I)ate, I 760 .

943 Small Color Print by Harunobu; picnic party. Date, $1 ; 50$.

944 Large Color Print by Utamaro; ladies in boat nnder parasol. Date, I8go.

945 Large Color Print by Ltamaro; ladies in a boat. Date, .1890 .

946 Large Color Print by Ltamaro; lady standing in a boat. Date, 1890.

947 Silver Falcon on Bronze Anchor; made by Chokichi Sizuke. During the naval battle between JapanChina on the Yellow Sea, a white falcon perched upon the mast of the Japanese flagship. Aiter the victory the Japanese officers thought it a mascot. Hence the origin of the design. The falcon is of solid silver, feet plated with gold. Received first award in National Sculpture Exhibition in Lyeno in the spring, 1896 . Height, $30 \mathrm{r}-2$ inches.

948 Jewel Liasket; design in bronze on the cover represents a badger hidden in the basket striving to catch the bird near by. Has red silk cord and tassel. roo years old.

949 Bronze Hanging Lantern; in form of cone. Perforated design. Fine quality of bronze.

950 Large Bronze; lion playing with ball. Wonderfully well wrought green bronze. Brought from Japanese temple garden expressly for this sale. (See interesting illustration.) Height, 37 inches; length, 47 inches.

95I Old Bronze Mask Pace of imp "Hannia"; splendid workmanship. Maker unknown.

$95^{2}$ Old Bronze Mask; mate to above.

953 Gold Lacquer Box; entire surface is covered with Japanese clover design in gold. Words fail to express the beaty of this charming bit of lacquer. Made by Harumasa. Date, г $77^{\circ}$ 
954 Gold Lacquer Incense Pox; in form of plum blossom. Charming brocade pattern. Ioo years old.

955 Gold Lacquer Box; decorated with Imperial chrysanthemum crest in gold. 200 years old.

$95^{6}$ Gold Lacquer Incense Box; beantifully decorated in gold inside and out. Date, I750.

957 Tsuishu Lacquer Box; three horses carved on the cover. 200 years old.

958 Ivory Carving; Japanese warrior. Represents a warrior in an attitude of defence. Suit of armor, sword, etc., faithfully executed. Stern expression on the face. Height, 6 inches. Carved by Tomoaki.

959 Ivory Carving; goose plucking its feathers. Eyes are imlaid with precious stones. Carved by Issin. Received second award at National Sculpture Exhibition in 1896.

960 Gander; mate to one above. This pair are one of the most beantiful ivory carvings ever brought to this country.

gó I Ivory Carving; old man returning fron fair. Height, 4 inches.

962 Ivory Carving: frog. Eyes inlaid with precious stones. Carved by Mitsuhiro. Exquisite little piece.

963 Ivory Carving; frog. Mate to above.

964 Ivory Box; carved out and ornamented by Kaigiokusai. This box is nearly roo years old. Has beautiful spray of autumnal flowers carved on the cover. Fine quality seldom seen at the present day. Height, 3 inches. Diameter, 3 3-4 inches.

965 Ivory Umbrella Handle; three monkeys carved out in relief. Length, 8 I-4 inches.

966 Ivory Lmbrella Handle; three monkeys carved in relief. Length, 6 3-4 inches.

967 Ivory Umbrella Handle; monkeys carved in relief. Length, 6 3-4 inches. 
$967+\frac{1}{4}$ Embroidered Silk Screen; with carved frame. Pair of crows perched on limb of tree. The ground is costly white Kohaku silk. One of most charming works accomplished by Takashimaya of Kioto. Frame is elaborately carved black persimmons wood. Height. 3 feet I I inches; width, 2 feet 2 inches.

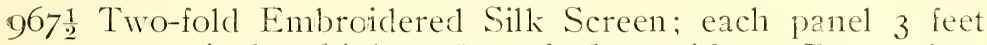
Io inches high and 24 inches wide. Decoration, maple tree with locust crawling on the trunk; spray of wistaria flowers. Each panel has beantiful brocade mat. Back of screen has water color painting, "Takawo in Maple Season." Made by Takashimaya of Kioto.

\section{IMPORTANT GOLD LACQUER INROS.}

968 Gold Lacquer Inro by Kajikawa; has ivory netsuke. Date, i73o.

969 Gold Lacquer Inro by Inagawa; plum tree in blossom and crow. Date.

970 Gold Lacquer Inro by Kenya; has ivory netsuke. Date, I700.

97 I Gold Lacquer Inro by Kajikawa: has ivory netsuke. Very fine quality. Date, i750.

972 Gold Lacquer Inro by Shiginaga; swallows hovering over water. Date, i7zo.

973 Inro by Somada; grape vines inlaid with Mother of Pearl. Netsuke to match. Date, 1750.

974 Gold Lacquer Inro by Kwanshosai. Decoration, birds and flowers. With gold inlaid Netsuke. Date, I 730 . 
975 Gold Lacquer Inro by Shiwomi. Mikadoss carriage. Dite, 1740.

976 Gold Lacquer Netsuke by Yoyusai. Date, I 730.

977 Gold Lacquer Inro by Inagawa.

978. Fudo in Shrine. Wonderful carving from sandal wood. Garments beautifully inlaid in gold. Shrine finished with exquisite gold lacquer trimmed with solid gold. Carved by Munesada. Signed on the back of shrine. Date, 4585.

979 Gold Lacquer Cabinet by Korin. Decoration, two kinds of Imperial crests in gold relief. Signed Okio Korin on the back of hinged door. Wonderful design executed by Korin. Height, 8 I-2 inches; length 12 I-2 inches.

980 Fire Place, Mirror frame and mantel. This wonderful piece was carved from old oak taken from the gate of famous Castle of Akoh in the Province of Harima and was standing for last two centuries. This is the Castle connected with the Forty-seven Ronins; the story of whom is so familiar to American travellers in Japan. The wood gives forth a peculiarly sweet odor. This oak is of the fincst grain and it is impossible to be duplicated. Height, 12 feet; width 6 feet, 6 inches. (See illustration.)

981 Bronze Hanging Lantern. Made of fine green bronze, has four perforated bronze screen sides. With iron chain. Date, I 800 .

982 Bronze Vase. Tall with slender neck with lizard in pursuit of spider. Height, I I inches. With teakwood stand.

983 Ancient Decorated Bronze. Figure of Confucius. This magnificent bronze of eighth century is the most wonderful specimen now in existence. Dignified pose of the saint is beyond need of praise. Height, 12 inches. Has gold lacquer stand. (See illustration.) 


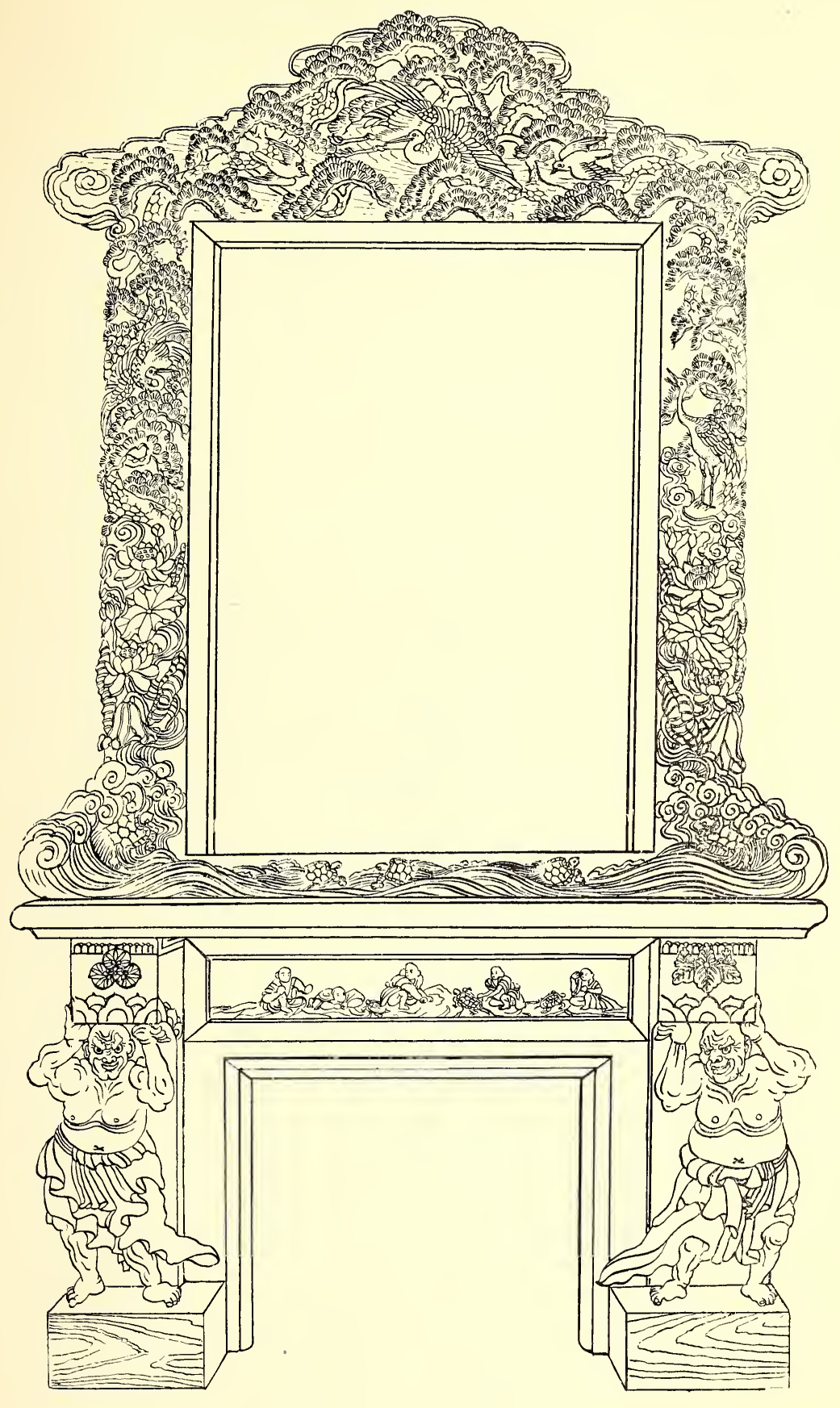

No. $9^{80}$ 



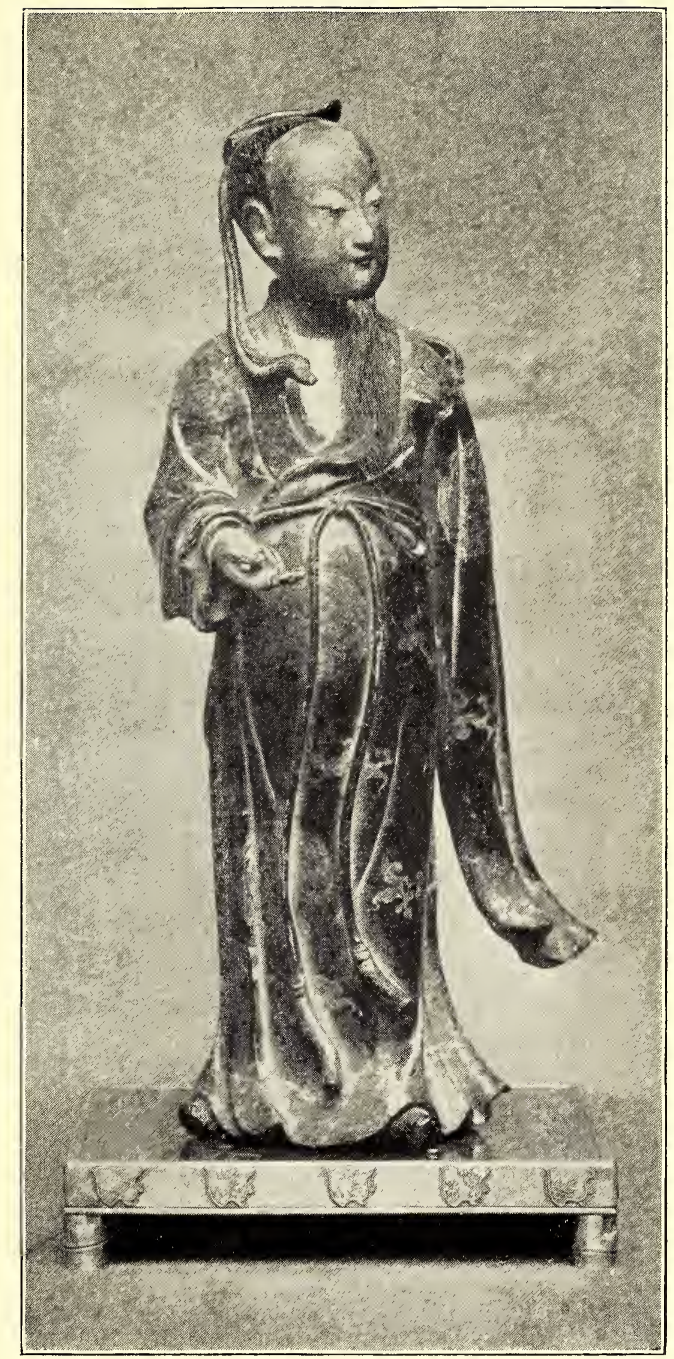

No. 983 . 




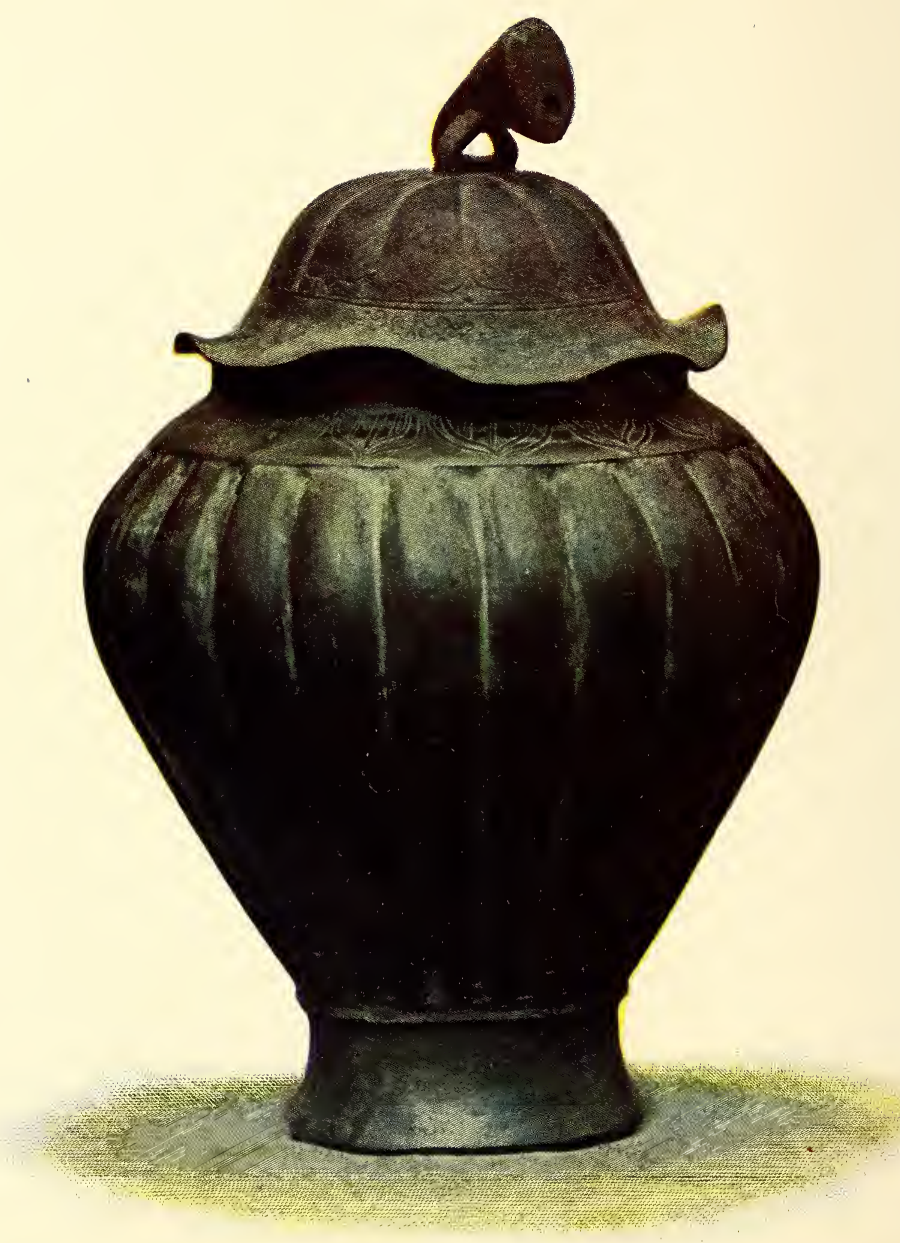

No. 988

Ancient Bronze Jar, 7 th Century. 
9831/2 Ancient Colored Bronze. Figure of Kwan-non (Goddess of Mercy.) This together with number 983, Figure of Confucius, make the most wonderful pair of old colored bronzes ever brought over to this country. The face has an expression of unusual benevolence and dignity. Drapery falls about the figure in graceful folds. Date, I $300 \mathrm{~A}$. D. Height, 9 inches. With carved oakwood stand.

984 Bronze Vase. Cylindrical form. Originally was Scripture Case. Inscription translated says that "Yoritomo, the first Japanese Shogun, presented this to the Temple in the year I I97." It has mosslike green color. One of the most important bronze objects in the collection. The date of bronze valuable to all bronze collectors. Height, 9 I-4 inches.

985 Temmoku Bowl. Fine rabbit's hair glaze in deep blue. Silver rim. Made about Eighth Century.

986 Kioto Teapot. Made by Rantei. Delicate decoration representing Kiyomizu Temple in Spring.

987 Chinese Pottery Dish, flat, with three legs. Gorgeous "dragon's blood" glaze over green. Made about I 300 . With teakwood stand.

988 Ancient Bronze Jar with cover. In form of Lotus flowers. This valuable bronze was brought from China to Japan in remote time, and was one of the treasures in Temple of Soga in suburbs of Kioto. According to the opinion of Mr. Wakai, a celebrated expert, Yusaku Imaizumi, Esq., president of Kinto School of Fine Arts and others, it is a magnificent specimen of Chinese bronze of Seventh Century. It may be said to be a criterion for all Oriental bronzes. It was much regretted by all Eastern connoisseurs that it should go outside of Japan. Height, I 7 inches. (See colored illustration.)

988 $1 / 2$ Old Bronze Jar. Beautiful green bronze, very fine quality. Date about i650. Height, 24 inches. 
989 Embroidered Silk Temple Hanging. Needle painting of Kiyomizu Temple and Otowa Mountain. Its famous promenade temple porch, sacred waterfall and pagoda skillfully colored and composed by the needle paints. This embroidery with all its wealth of color, is a clear, well-defined picture of Kiyomizu. It is one of the most skillful pieces of work ever created by Normura after the labor of more than six months. The border is a valuable gold brocade. Has beautiful repousse mountings. Size, $68 \times 80$ inches.

990 Large Embroidered Silk Temple Hanging. Group of Japanese native storck in bamboo forest. Charming design and exquisite coloring. Noble looking white storks in contrast to beautiful green bamboo make this embroidery particularly attractive. It is incredible, such a wonderful rendering of light and shade, not the work of the brush, but of the needle in the hands of master craftsman. This is another piece of which Nomura is very proud. Has costly gold brocade border. Size, I I 2 x 68 inches.

99 I Embroidered Silk Panel used over the threshold. Two dragons facing each other. Emblem of precious stone in center. Whole ground is covered with needle work. Length, 9 feet; width 25 inches.

992 Embroidered Silk Hanging. Eagle perched on the pine tree holding snake. Beautiful dark brown color lighted with delicate blue waterfall in foreground. Has fine brocade silk border. 7 feet $\times 4$ feet 9 inches.

993 Embroidered Silk Hanging. Japanese flower garden. Houses and temples in distance. Spray of chrysanthemum, lilies and various other flowers in foreground. Very elaborate and attractive piece. Has gold brocade border. Size, 7 feet by 5 feet.

994 Embroidered Silk. 3 feet 4 inches square. Sacred Howo Bird.

995 Embroidered Silk Square. 3 feet $\times 3$ feet. Chrysanthemum garden and stone lantern. 
996 Ancient Silk Brocade. Fine cherry blossom pattern woven with gold. Lined with green silk. Date about I 7 I 7 .

997 Donsu Silk Brocade

998 Donsu Silk Tapestry.

999 Donsu Silk Tapestry.

I000 Embroidered Silk Square. Conventional Kiri leaves.

IOOI Embroidered Silk Square. Conventional chrysanthemum.

I OO2 Embroidered Silk Square. Dragon and wave design. Has gold brocade border.

IOo3 Teakwood Cabinet. Height, 5 feet 2 inches; width, 30 inches. Entire cabinet is made of elaborately carved teakwood. Sliding doors in upper part are inlaid with enamel in design of cherry blossoms, in delicate pink and blue. The two drawers at the base are also inlaid with enamel plates of floral design. Open shelves are divided into several "chigaidana" suitable for holding bric-abrac.

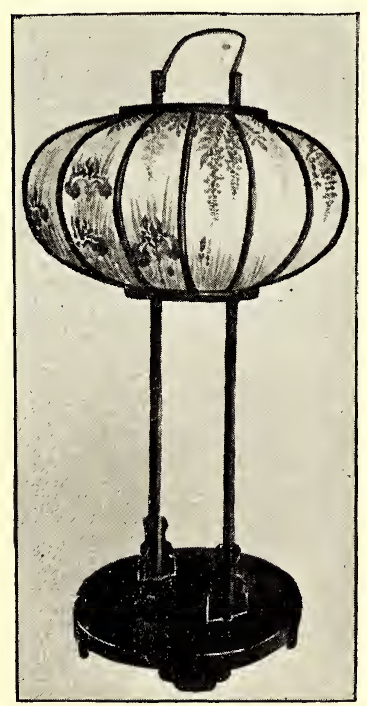

No. 27 . 


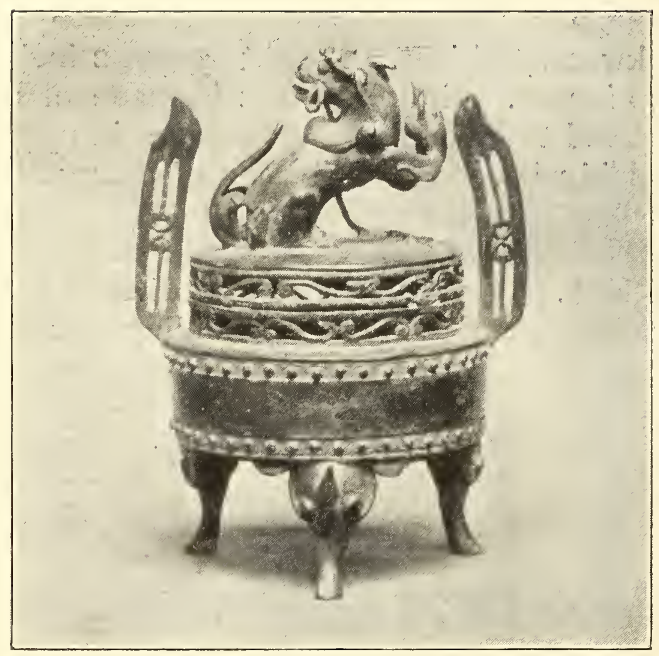

No. 301 . 


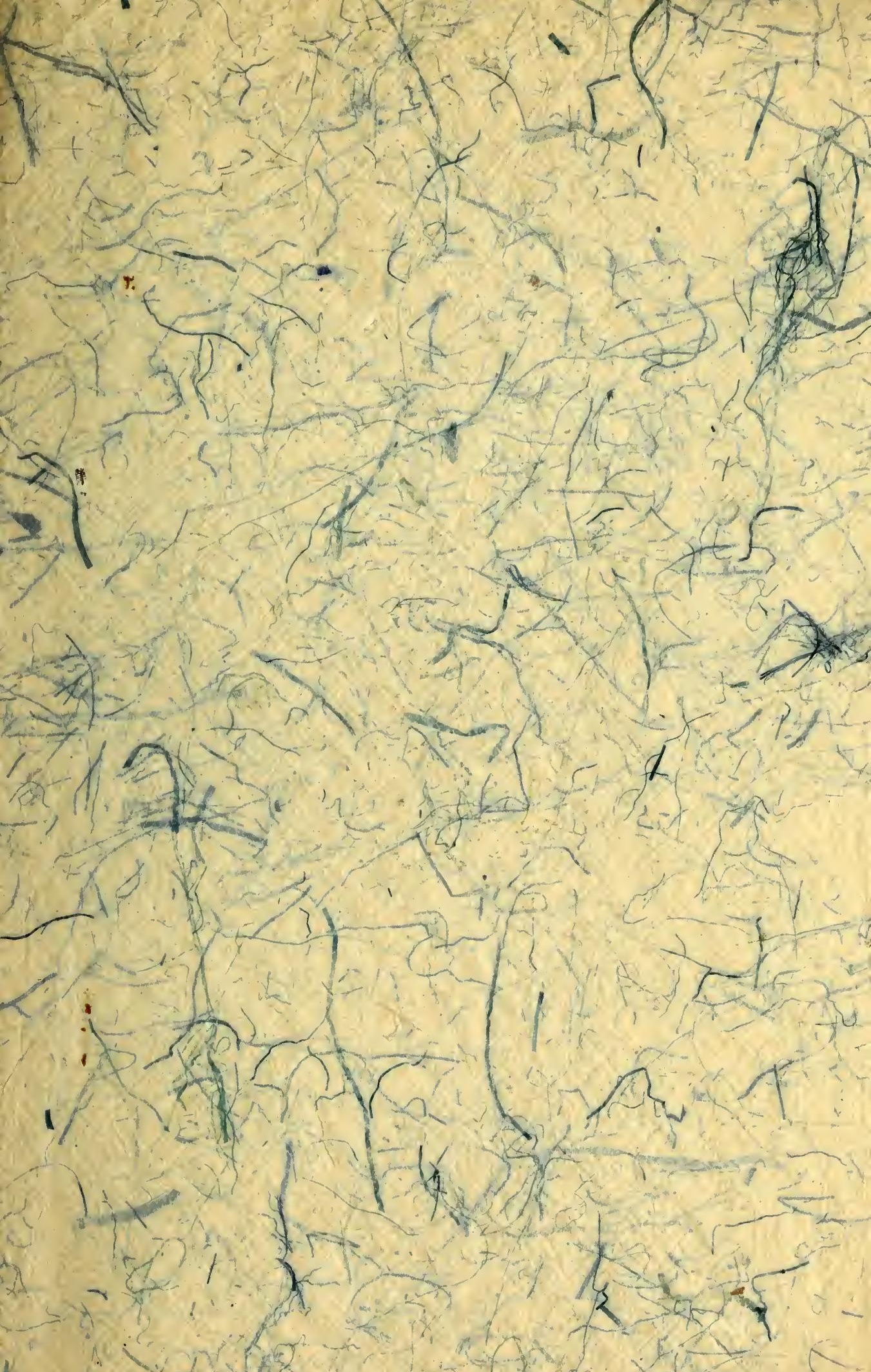




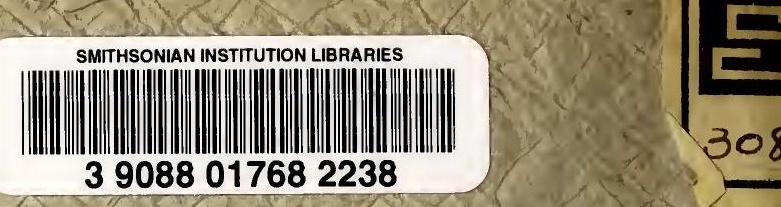

39088017682238

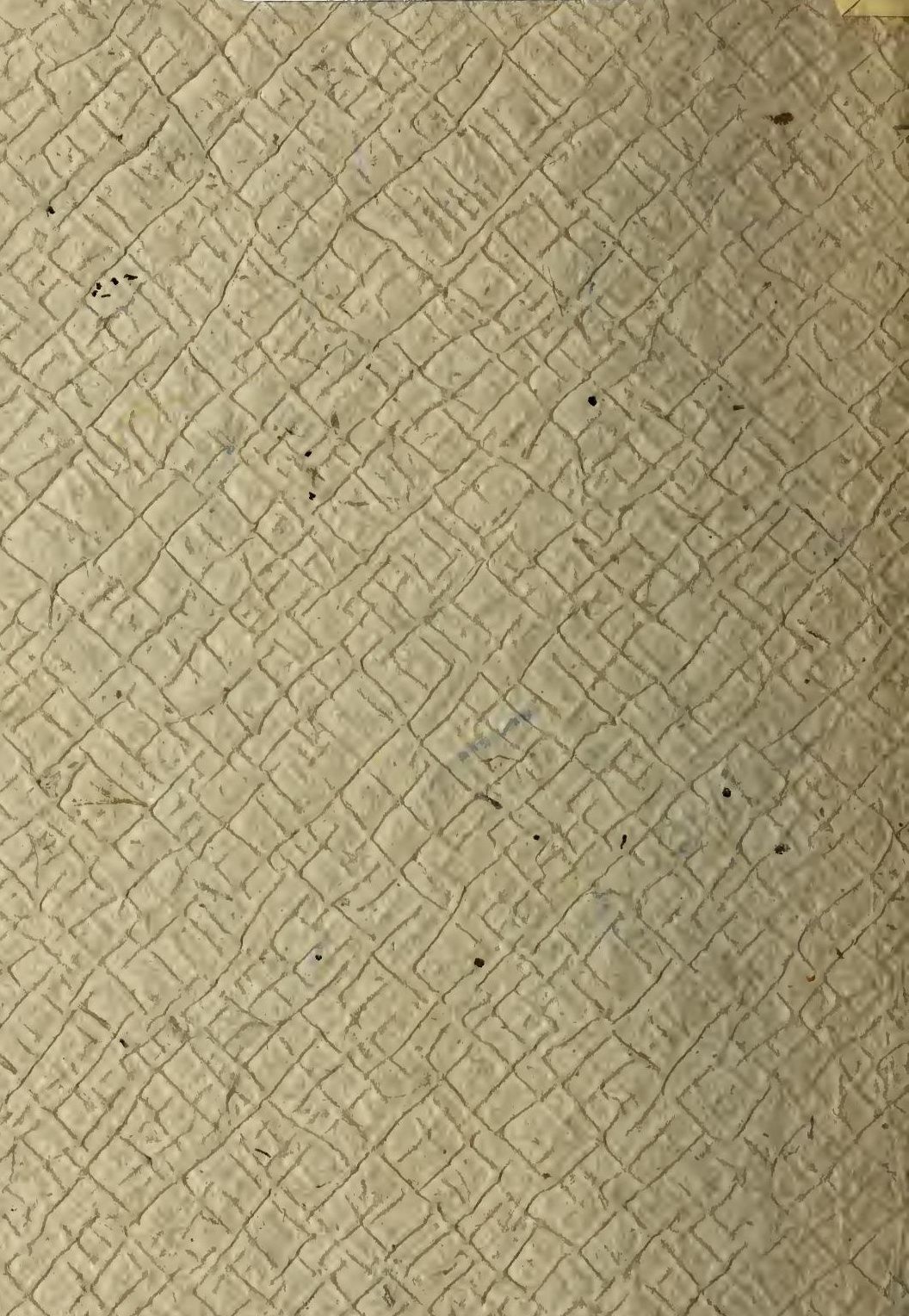

$4-2$ 